UNIVERSIDADE DE BRASÍLIA

INSTITUTO DE RELAÇÕES INTERNACIONAIS

PROGRAMA DE PÓS-GRADUAÇÃO EM RELAÇÕES INTERNACIONAIS

MARIA HELENA DE AGUIAR NOTARI

OS PAPÉIS PROJETADOS PELA POLÍTICA EXTERNA BRASILEIRA

PARA O ORIENTE MÉDIO DURANTE OS GOVERNOS LULA (2003-2010) 


\title{
OS PAPÉIS PROJETADOS PELA POLÍTICA EXTERNA BRASILEIRA PARA O ORIENTE MÉDIO DURANTE OS GOVERNOS LULA (2003-2010)
}

\author{
Dissertação apresentada à Universidade de Brasília \\ como requisito para obtenção do título de Mestre em \\ Relações Internacionais na área de concentração \\ História da Política Exterior do Brasil
}

Orientador:

Prof. Dr. Luiz Daniel Jatobá França

Doutor em Ciência Política pela Universidade do Estado do Rio de Janeiro, UERJ

Banca Examinadora:

Prof. Dr. Antonio Jorge Ramalho da Rocha

Doutor em Sociologia pela Universidade de São Paulo, USP

Prof. Dr. Virgílio Caixeta Arraes

Doutor em História pela Universidade de Brasília, UnB 
Para Pedro Cincinato Ferreira de Aguiar (in memoriam) 


\section{AGRADECIMENTOS}

Agradeço à minha mãe, Maria Inêz de Aguiar, por ensinar-me o amor às letras e aos cadernos. Seu exemplo de dedicação por seu trabalho e por seus pacientes, além de sua incansável luta diária no consultório, inspiram-me e dão-me forças para continuar carregando "uma mochila de livros nas costas" por mais de duas décadas.

Agradeço à amiga Cristiane Decat, por incentivar-me a fazer as provas de seleção do mestrado do IREL e por fazer-me lembrar meu amor genuíno pelos estudos. Agradeço ao meu marido, Raimundo Seixas, pela paciência e pela tolerância em comigo dividir a vida, com suas dúvidas e seus questionamentos.

A finalização deste trabalho seria impossível sem o carinho e a eficiência dos funcionários da secretaria do IREL, em especial, Odalva, Celi, Anderson e Wanderlei. Agradeço a todos vocês, que acompanham minha vida acadêmica no IREL, desde 2001, inclusive aos amigos da Papelaria Asa.

Merecem especial agradecimento todos os professores do mestrado do IREL, em particular, Antonio Carlos Lessa, Antonio Jorge Ramalho, José Flávio Sombra Saraiva e Vânia Carvalho Pinto. Serei sempre grata pelo acolhimento, pelos ensinamentos teóricos e metodológicos, pela confiança, pelo respeito e, sobretudo, pelo exemplo de profissionalismo acadêmico.

Não poderia deixar de mencionar minha gratidão aos colegas do mestrado que deixaram mais suave o caminho percorrido ao longo desses dois anos, em especial, a querida amiga e companheira de trajetória Natália Bandeira, além de Luciana Campos, Tomas Moerman, Aline Alencar, Ivan Elizárov, Gabriel Dizner e Giordano Almeida. Agradeço a minha irmã curitibana, Laura Gandolfo, pelos cafés e pelo incentivo na reta final do trabalho e ao jornalista e fotógrafo da Folha de S. Paulo, Alan Marques, que, gentilmente, cedeu suas fotos.

Aos meus chefes do Itamaraty e da Secretaria de Direitos Humanos nos últimos dois anos, os secretários Rubens Campana, Edison Rosa, Victoria Balthar e Juliana Benedetti, agradeço o suporte, a compreensão com os horários acadêmicos e a troca de artigos sobre Oriente Médio e Política Internacional.

Registro, finalmente, a minha gratidão e o meu respeito ao professor Daniel Jatobá, por ter aceitado ser meu orientador do trabalho já iniciado e em situação não tradicional. Seus valiosos conselhos, opiniões e comentários foram fundamentais para a conclusão a contento. 


\section{RESUMO}

A presente dissertação tem por objetivo descrever e analisar os principais papéis projetados pela política externa brasileira para o Oriente Médio, durante os governos Lula (2003-2010). Argumenta-se que a diplomacia brasileira atuou naquela região, por meio de cinco papéis centrais: ponte entre povos, países e regiões; defensor da paz e dos direitos humanos; agente promotor de assistência humanitária internacional; criador de novos arranjos políticos, diplomáticos e econômicos alternativos ao status quo; mediador de conflitos. Para realizar esta pesquisa, utilizou-se do método de análise de discurso e de conteúdo documental. Foram examinados discursos dos principais formuladores da $\mathrm{PEB}$, fontes documentais primárias e secundárias, além das literaturas nacional e estrangeira, relativas ao recorte histórico e temático. A análise dos cinco principais papéis projetados pelo Brasil para a região geográfica do Oriente Médio durante os dois governos Lula visa descobrir o principal objetivo do país naquela região, ou seja, a intenção de fundo da diplomacia brasileira, ao investir, no Oriente Médio, tempo, recursos financeiros e pensamento estratégico.

Palavras-chave: História da Política Externa do Brasil. Oriente Médio. Questão palestina. Declaração de Teerã. Reforma da governança global. 


\begin{abstract}
The present dissertation aims to describe and analyze the main roles played by the Brazilian Foreign Policy in the Middle East during the Lula administration (20032010). The main argument is that the Brazilian diplomacy acted in that region by playing five central roles: acting as a bridge among peoples, countries and regions; defending human rights and peace; promoting international humanitarian aid; creating new economic, political and diplomatic arrangements - as alternatives to the status $q u o$; mediating conflicts. This research was conducted using discourse and document analysis. It had been analyzed the speeches of the main Brazilian foreign policymakers, primary and secondary document sources, and national and international literature related to this specific and historical moment and theme. By analyzing the five main roles played by Brazil in the geographic region of Middle East during Lula's two mandates, this dissertation aims to discover the main goal of Brazil in the region, in other words, the underlying intention of Brazilian diplomacy in investing its scarce time, financial resources and strategic thinking in Middle East.
\end{abstract}

Keywords: History of Brazilian Foreign Policy. Middle East. The Israeli-Palestinian Conflict. Tehran Declaration. Global Governance Reform. 


\section{SUMÁRIO}

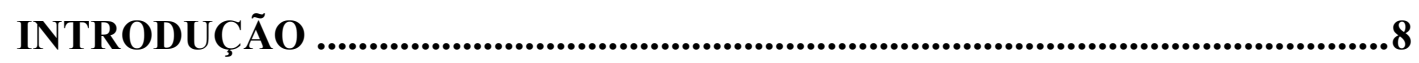

CAPÍTULO 1: A Política Externa Brasileira durante o governo Lula .................13

1.1 Continuidades e rupturas..........................................................................13

1.2 Posições históricas do Partido dos Trabalhadores em política externa......21

1.3 Política Externa durante o governo Lula: características gerais .................25

1.4 Objetivos da Política Externa Brasileira durante os anos Lula ...................29

1.5 Métodos de implantação dos objetivos da PEB de Lula............................32

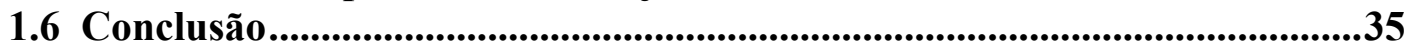

CAPÍTULO 2: Os papéis secundários projetados pela Política Externa Brasileira para o Oriente Médio durante os governos Lula (2003-2010) ...............................38

2.1 Role Theory: breve apresentação .................................................................37

2.2 Ponte: o pré-papel e a "porta de entrada" para papéis posteriores ............42

2.3 O Brasil como defensor da paz e dos direitos humanos ...............................54

2.4 A expressão prática da defesa da paz e dos direitos humanos: o Brasil como agente promotor de assistência humanitária internacional.......................56

2.5 O Brasil como criador de novos arranjos políticos, diplomáticos e econômicos alternativos ao status quo .....................................................................65

2.5.1 A cúpula América do Sul - Países Árabes (ASPA) ................................66

2.5.2 Os acordos comerciais do MERCOSUL com países do Oriente Médio ....74

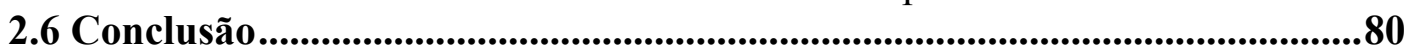

CAPÍTULO 3: Os esforços de mediação da política externa brasileira nos casos da questão palestina e da questão nuclear iraniana ....................................................81

3.1 O Brasil como mediador de conflitos e construtor de consensos.................81

3.2 A mediação brasileira na questão palestina durante os governos Lula......82

3.2.1 Concepção do papel nacional de mediador...........................................82

3.2.2 Percepção por outros atores do papel do Brasil como mediador .................84

3.2.3 Principais linhas de posicionamento da gestão Lula com relação à questão

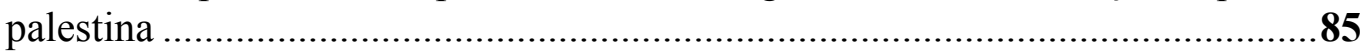

3.2.4 Os grandes temas da questão palestina e o Brasil .....................................87

3.2.5 Sugestões da PEB para o conflito Israel - Palestina ..................................91

3.2.6 O reconhecimento do Estado palestino pelo Brasil .................................105

3.3 A mediação brasileira na questão nuclear iraniana ..................................109

3.4 Conclusão ................................................................................................19

CONSIDERAÇÕES FINAIS. Error! Bookmark not defined.

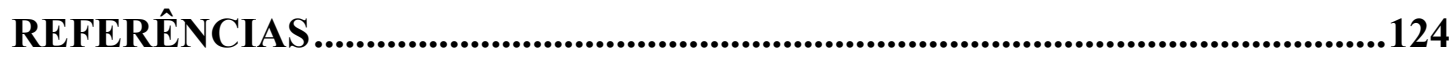

ANEXOS. 


\section{LISTA DE FIGURAS E TABELAS}

Figura 1: PEB Lula - objetivos, estratégias e métodos de implementação (LESSA, 2010)

Figura 2: PEB Lula - objetivos, estratégias e métodos de implementação (CERVO, 2012)

Figura 3: Características, objetivos e métodos de implementação da Política Externa de Lula 32

Figura 4: A Role Theory e as fontes do comportamento humano 39

Figura 5: Papéis formulados pela PEB para a região do Oriente Médio durante o Governo Lula (2003-2010) . .44

Figura 6: Organograma da Cúpula ASPA .65

Figura 7: Logotipo da Cúpula ASPA 67

Tabela 1: Temáticas e abordagens - PEB Cardoso e PEB Lula .19

Tabela 2: Países e partidos políticos componentes do Foro de São Paulo 21

Tabela 3: Justificativas da PEB para legitimar-se como ponte entre povos e regiões

Tabela 4: Assistência humanitária prestada pelo Brasil a países do Oriente Médio por ordem cronológica

Tabela 5: Acordos comerciais entre o MERCOSUL e os Países do Oriente Médio, assinados ao longo do governo Lula (2003-2010)

Tabela 6: Proposta da PEB para inclusão de novos atores no processo de paz no Oriente Médio, em especial, na questão palestina

Tabela 7: Posicionamento oficial do governo brasileiro por ordem cronológica em relação ao conflito Israel-Palestina (2003-2010) 


\section{INTRODUÇÃO}

Eu me chamo Silva. Meu médico se chama Khalil. Meu cirurgião se chama Cuttait. Meu hospital é o Sírio-Libanês. Para mostrar minha admiração [pelos árabes], assisti ao sacrifício de um cordeiro, comi coração e bebi arak... E não sei se já não havia um libanês infiltrado no navio de Cabral $^{1}$.

O relacionamento do Brasil com a região do Oriente Médio remonta ao século XIX quando, entre 1871 e 1876, o Imperador D. Pedro II realizou viagem de caráter pessoal à Palestina e ao Império Otomano ${ }^{2}$. Admirador da cultura material e imaterial árabe e do Oriente Médio, D. Pedro II esteve duas vezes na região: visitou o Egito em 1871 e, cinco anos depois, o Líbano, a Palestina e a Síria. A primeira visita de natureza verdadeiramente política de um chefe de Estado brasileiro à região, no entanto, ocorreu 132 anos depois, em dezembro de 2003, durante o primeiro mandato do Presidente Luiz Inácio Lula da Silva ${ }^{3}$.

Apesar dos fluxos migratórios quantitativos do Oriente Médio direcionados ao Brasil no século XIX e nas primeiras décadas do século XX, pode-se afirmar que, até o fim da II Guerra Mundial, a atitude da Política Externa Brasileira (PEB) era de certo desinteresse pela região. Todavia, com a ocupação do Brasil a um dos assentos não permanentes do Conselho de Segurança das Nações Unidas (CSNU) no biênio 19461947, a apatia brasileira para com a região médio-oriental mudou, principalmente, em função da aprovação do Plano de Partilha da Palestina e da criação do Estado de Israel, em 1947. Na ocasião, o presidente da Assembleia Geral das Nações Unidas (AGNU) era o brasileiro Oswaldo Aranha, e o Brasil votou favoravelmente à

\footnotetext{
${ }^{1}$ Declaração pronunciada pelo Presidente Luiz Inácio Lula da Silva em março de 2005, em São Paulo, durante comemoração vinculada à imigração libanesa.

${ }^{2}$ José Murilo de Carvalho (2007:148) conta que "no Egito, quando o Imperador foi conhecer as pirâmides, seus guias eram arqueólogos e egiptólogos". Acrescenta, "Em Alexandria, D. Pedro II recebeu telegrama do Brasil com a notícia da aprovação da Lei do Ventre Livre".

${ }^{3} \mathrm{Na}$ ocasião, o Presidente Lula visitou cinco países do mundo árabe - Síria, Líbano, Emirados Árabes Unidos, Egito e Líbia - entre os dias 3 e 10 de dezembro de 2003. Segundo comunicado à imprensa emitido pelo Itamaraty, a iniciativa do Governo brasileiro afirmava o grande interesse do Brasil em intensificar suas relações com todo o Oriente Médio, ao qual o Brasil está ligado por diversas vertentes. De acordo com nota oficial, o fato de a visita realizar-se no primeiro ano da administração Lula é, por sua vez, significativo da prioridade que o Governo imprime ao desenvolvimento do intercâmbio com os países árabes.
} 
resolução 181, que estabelecia a proteção dos lugares santos, o estatuto internacional de Jerusalém e o Plano de Partilha da Palestina (ROSA, 2000).

O denominado turning point da política externa brasileira para com a região do Oriente Médio ocorreu apenas na década de 1970, no contexto das sucessivas crises do petróleo. No período em questão, levando em conta a possibilidade de compensar, pelo comércio de exportação e pela penetração de empresas brasileiras de serviços de engenharia, os enormes gastos com petróleo de procedência árabe, o governo brasileiro passou a posicionar-se com relação aos grandes temas da política no Oriente Médio. Dessa forma, o Brasil condenou, de maneira incisiva, na ONU, a expansão territorial de Israel pela guerra, em detrimento dos países vizinhos e tornou explícita sua voz a favor da criação de um Estado palestino (CERVO, 2010).

De modo paralelo, durante o governo Médici, organizou-se a primeira visita oficial de um chanceler brasileiro ao Oriente Médio. Em seu livro de memórias, o exchanceler Mário Gibson Barboza descreve como foi a sua visita à região e pontua as principais diretrizes da PEB de Médici para a região (BARBOZA, 1992:213):"Parecia-me indispensável criar uma aproximação maior com Israel e com o mundo árabe, simultaneamente, sem perder de vista o necessário equilíbrio da posição política do Brasil em relação às duas partes no conflito".

De acordo com a interpretação do chanceler de Médici, o Brasil tinha posição singular no conflito árabe-israelense, em função do talento e da habilidade de Oswaldo Aranha em presidir a histórica AGNU, que criou o Estado judeu: “contávamos com a gratidão dos judeus e não sofríamos com o ressentimento dos árabes" (BARBOZA, 1992:214). A posição de equidistância entre os dois lados do conflito foi entendida por Mário Gibson Barboza como oportunidade para que o Brasil pudesse fazer contribuição para a questão árabe-israelense. O marco temporal do início do papel nacional de mediador de conflitos na região do Oriente Médio pode ser assinalado nessa ocasião.

Outro ponto histórico de inflexão na PEB para o Oriente Médio pode ser encontrado na gestão do chanceler Azeredo da Silveira, ocasião na qual o Brasil trocou o apoio a Israel por uma política de aproximação com os países árabes no Oriente Médio. Segundo palavras de Azeredo da Silveira, "a política externa do governo Geisel operou uma das mais profundas transformações no comportamento internacional do Brasil” (SPEKTOR, 2010). No que tange questões relativas ao Oriente Médio, não foi diferente, pois políticas específicas para a região foram 
definidas entre 1974 e 1979. O principal fato que caracteriza o período de mudança na PEB para posição em favor dos direitos dos povos palestinos foi o voto do Brasil na Resolução da AGNU que condenava o sionismo e classificava-o como forma de racismo. Segundo depoimento de Azeredo da Silveira, "o Brasil não aceitava minorias nacionais, pois o grande milagre do país era a convivência" (SPEKTOR, 2010:113).

Com o início do governo Lula, em 2003, a PEB passou a repensar a forma como iria projetar-se em relação ao mundo e à região do Oriente Médio, após período de grande distanciamento entre as duas regiões, durante a década de 1980 e as duas gestões do governo FHC. Pode-se afirmar, conforme explicado de modo detalhado no primeiro capítulo, que a PEB do Brasil para o Oriente Médio se insere nas características da nova política externa brasileira de universalismo, formação de alianças e cooperação sul-sul. Ademais, o Oriente Médio pode ser analisado como instrumento utilizado pela diplomacia do governo Lula para a busca de quatro de seus objetivos principais: a garantia da presença soberana do Brasil no mundo; a reforma da governança global; a conquista de assento permanente no CSNU; a expansão do comércio internacional do Brasil.

A estratégia para o estreitamento dos laços do Brasil com a região do Oriente Médio e a consequente busca por esses objetivos principais da PEB de Lula foram o impulso dado para as relações Sul-Sul e para a formação de novas coalizões e arranjos políticos, diplomáticos e econômicos. O Oriente Médio localiza-se na PEB do governo Lula como instrumento para evidenciar essas características e perseguir os objetivos da PEB, utilizando-se o método de aproximação e cooperação Sul-Sul.

Os questionamentos que motivaram o desenvolvimento desta pesquisa foram dois principais: de que forma a política externa se projetou para a região do Oriente Médio, durante o governo Lula? Qual é a sua real motivação em voltar-se para a região, até então, pouco prioritária no denominado "substrato normativo" da política externa brasileira (VARGAS, 2008)?

Para tentar responder a essas questões, utilizou-se do marco teórico do Role Theory, desenvolvido pelo professor canadense Kalevi Holsti na década de 1970, que tem por objetivo analisar o papel nacional concebido pelo próprio Estado no sistema internacional, a forma como os outros atores reagem a esse papel e suas consequentes ações em política externa derivadas desse papel. De acordo com Holsti (1970:238), o conceito de papel diz respeito à posição ocupada por um indivíduo, uma sociedade ou um Estado no sistema internacional e ao conjunto de normas e de expectativas de 
comportamento a ser aplicadas a todos aqueles que ocupam a mesma posição. $\mathrm{O}$ conceito postula que os atores conhecem as normas que constituem seu papel e, conscientes, tendem a adaptar seu comportamento aos papéis que ocupam.

Utilizando-se da metodologia de análise qualitativa de conteúdo de fontes primárias - como notas oficiais, relatórios, maços, discursos e entrevistas - e de fontes secundárias acerca de literatura acadêmica nacional e estrangeira sobre o tema, chegou-se à percepção de que a PEB durante os governos Lula (2003-2010) concebeu cinco papéis principais para o Brasil em relação à região do Oriente Médio: ponte entre os povos, países e regiões; defensor da paz e dos direitos humanos; agente promotor de assistência humanitária internacional; agente criador de novos arranjos políticos, diplomáticos e econômicos alternativos ao status quo; mediador de conflitos ou construtor de consensos.

Defende-se, ao longo da dissertação, que esses papéis estão dispostos de forma hierárquica, sendo o primeiro deles o de ponte entre os povos, um "pré-papel”, uma espécie de porta de entrada e instrumento retórico para que os formuladores de política externa brasileira ganhem empatia de seus interlocutores árabes, iranianos ou judeus e, assim, consigam projetar diferentes objetivos do Brasil para a região. Argumenta-se, por outro lado, que o papel de mediador de conflitos ou construtor de consensos foi o central e primário da política externa brasileira na região, por meio do qual o Brasil se projetou como global player em questões de segurança internacional, de forma assertiva, em temas, como a questão palestina e a questão nuclear iraniana.

Esta dissertação está dividida em três capítulos principais. O primeiro tem por objetivo expor as linhas gerais da PEB durante os dois mandatos do Presidente Luiz Inácio Lula da Silva (2003-2010). Analisam-se, posteriormente, as continuidades e as rupturas da PEB dos governos FHC (1994-2002) em relação à PEB dos dois mandatos do governo Lula, mostrando a diferença de interpretação de conceitos existente na literatura nacional e na estrangeira. Além disso, expõe-se de que forma as posições históricas do Partido dos Trabalhadores (PT) em política externa influenciaram os oito anos de governo Lula. Por fim, elabora-se uma síntese dos principais objetivos da PEB dos governos Lula e seus principais métodos de implantação.

O segundo capítulo objetiva apresentar os principais conceitos do marco teórico do Role Theory, utilizados ao longo da dissertação: concepção do papel 
nacional, percepção do papel nacional e desempenho do papel nacional ${ }^{4}$. Argumentase em momento posterior que o Brasil se utilizou de quatro papéis secundários ${ }^{5}$, além de seu papel primário, para projetar sua política externa no Oriente Médio, ao longo do governo Lula e atingir um de seus objetivos principais que fazem parte do "substrato normativo da PEB": a reforma da governança global e, em especial, do Conselho de Segurança das Nações Unidas. Evidências práticas e numéricas são empregadas para sustentar esse argumento.

Por fim, no terceiro capítulo, apresenta-se a conceituação e a análise do principal papel desenvolvido pela PEB no Oriente Médio, durante o governo Lula: o de mediador de conflitos e construtor de consensos. Ensaia-se, dessa maneira, a exposição do posicionamento brasileiro em dois casos nos quais as habilidades de negociação e de mediação da diplomacia brasileira foram mais repercutidas internacionalmente, mais complexas e mais emblemáticas: a mediação na questão palestina e a mediação na questão nuclear iraniana.

\footnotetext{
${ }^{4}$ Os títulos originais dos conceitos contidos no artigo intitulado National Role Conceptions in the Study of Foreign Policy, publicado por Kalevi Holsti em 1970, são: national role conception, national role perception e national role performance (HOLSTI, 1970).

${ }^{5}$ São eles: ponte entre os povos e as nações, defensor da paz e dos direitos humanos, agente promotor de assistência humanitária internacional e agente criador de novos arranjos políticos, diplomáticos e econômicos alternativos ao status quo.
} 


\section{CAPÍTULO 1: A Política Externa Brasileira durante o governo Lula}

O presente capítulo tem por objetivo apresentar as linhas gerais da política externa brasileira durante os dois governos de Luiz Inácio Lula da Silva (2003-2010). Por meio de análise de seu modus operandi, busca-se, primeiramente, identificar as continuidades e as rupturas da política externa dos anos Lula em relação à implantada nos anos de governo FHC (1995-2002). Realiza-se, em seguida, resgate histórico acerca da influência das ideias do Partido dos Trabalhadores (PT) e de seus principais foreign policy makers sobre a política externa exercida de 2003 a 2010, no Brasil.

O modus operandi da política externa do governo Lula é analisado, dessa maneira, por meio da identificação, na literatura acadêmica, dos principais objetivos e dos respectivos métodos adotados por essa política. Observa-se que um dos objetivos principais da PEB de Lula, a expansão da presença soberana do Brasil no mundo por meio de ampla projeção da imagem do país, de maior participação nos fóruns multilaterais e de maior representatividade diplomática, foi largamente conquistado ao longo dos oito anos de governo Lula.

\subsection{Continuidades e rupturas}

Ao longo do governo Lula, tanto nos meios acadêmicos como nos círculos políticos e diplomáticos, uma série de debates foi levantada acerca das continuidades e das rupturas da Política Externa do governo Lula, em relação aos oito anos de governo de Fernando Henrique Cardoso. As interpretações quanto à prevalência de linhas de ruptura ou de continuidade em relação aos dois governos divergem tanto entre pesquisadores quanto entre formuladores e executores da política externa brasileira. A tendência, no entanto, é as análises que ressaltam as rupturas tomarem mais espaço na literatura nacional e as análises que destacam as continuidades terem força na literatura estrangeira, particularmente a norte-americana.

Segundo Paulo Roberto de Almeida (2003), as linhas de ruptura, apesar de maior dificuldade na implantação, tenderam a prevalecer em relação aos elementos de continuidade. De acordo com sua apreciação, a diplomacia do governo Cardoso foi abordada tradicionalmente, tendo o Itamaraty como ator principal e privilegiando-se 
temas e questões econômicas. O governo Lula, na visão de Almeida (2003), teve a intenção de implantar política externa mais pragmática - menos presidencialista buscando exercer liderança regional e internacional por meio de atitude assertiva em torno da afirmação da soberania e dos interesses nacionais. Dialogando com Almeida (2003), Amorim (2010) avalia que a PEB dos anos Lula foi um dos principais motivos para a renovação da autoestima do país entre 2003 e 2010, classificando-a como criativa e imaginativa.

De forma paralela, acadêmicos e pesquisadores brasileiros tendem a enfatizar as linhas de ruptura da política externa brasileira do governo Lula em relação ao governo predecessor. Segundo Miriam Gomes Saraiva (2004) e Luiz Souto Maior (2003), a PEB do governo Lula rompeu com a de FHC no momento em que a “diplomacia dos interesses nacionais" do governo Lula substituiu a "diplomacia de prestígio pessoal" de FHC. Lula acreditou, segundo os referidos autores, na possibilidade de consolidação da multipolaridade diante da unipolaridade do período após a Guerra Fria, adotando política externa mais nacionalista - privilegiando os interesses locais e regionais - e mais afirmativa em relação às dos governos que o antecederam desde 1990.

Enfatizando as divergências entre as duas políticas externas, Bernal Meza (2010) classifica a diplomacia do governo FHC como personalista e presidencial bastante diversa da por ele denominada "diplomacia da Nação" do governo Lula, durante a qual, segundo o pesquisador argentino, tentou-se implantar o tipo ideal de Estado logístico. Segundo Meza (2010), durante a administração Lula, o Brasil projetou-se internacionalmente, de maneira mais ativa e multilateral, no que diz respeito tanto às questões econômicas internacionais quanto às questões de segurança. Uma das principais tendências da PEB de Lula, nesse sentido, foi a recuperação da importância da construção de coalizões e de alianças entre países similares.

Com o foco da análise nas mudanças partidárias internas no sistema político brasileiro a partir de 2003, Berringer e Boito (2013) ressaltam as linhas de ruptura da PEB do governo Lula com base na mudança política no interior do bloco político no poder. Segundo essa análise, "a grande burguesia interna brasileira - fração da classe capitalista que mantém base própria nacional de acumulação de capital - ascendeu politicamente em prejuízo do capital financeiro internacional e de seus aliados internos" (BERRINGER \& BOITO, 2013: 31). Essas mudanças, consequentemente, repercutiram na política externa, econômica e social do novo governo. Conforme os 
autores (2013), a nova política externa iniciada durante o governo Lula pode ser explicada por meio das mudanças na política interna brasileira uma vez que a política externa de Lula passou a articular-se com a nova política econômica, de modo a priorizar seus interesses.

No que diz respeito às linhas de continuidade, singular contribuição nacional foi dada por Cervo (2004; 2010; 2012), que elaborou os conceitos de "acumulado histórico da diplomacia brasileira" e de "Estado Logístico", para ressaltar as linhas de continuidade da PEB de Lula em relação à PEB de Cardoso. Segundo o historiador, apesar das diferenças entre as duas diplomacias, o modo de fazer política externa, a partir do início do governo Lula, preservou o acumulado histórico da diplomacia brasileira, ou seja, os princípios tradicionais da política exterior brasileira de autodeterminação dos povos, de não intervenção, de pacifismo, de cordialidade oficial com os vizinhos e de respeito ao direito internacional. Corroborando esse argumento, Lessa (2010) observa linhas de continuidade entre a PEB do governo Lula e a política externa implantada na década de 1990. Na visão dos autores, a diplomacia do governo Lula utilizou-se de tendências surgidas anteriormente, como a ascensão de novos mercados, a emergência de novos temas na política internacional e a valorização de foros multilaterais para consolidar-se de forma autônoma.

Outra importante linha de continuidade observada por Cervo (2012) é a introdução do paradigma do Estado Logístico durante a administração FHC e sua consolidação durante o governo Lula. Segundo Cervo (2012:529):

Logístico é aquele Estado que não se reduz a prestar serviço, como fazia à época do desenvolvimentismo, nem a assistir passivamente às forças do mercado e do poder hegemônico, como se portava à época do neoliberalismo. Logístico, porque recupera o planejamento estratégico do desenvolvimento e exerce a função de apoio e de legitimação das iniciativas dos outros atores econômicos e sociais, aos quais repassa responsabilidades e poder.

Na visão de Cervo (2004; 2010; 2012), o Estado logístico desenvolvido na era Lula colocou-se a serviço do desenvolvimento nacional, recuperando a autonomia decisória na esfera da política perdida, durante os anos de inspiração da política neoliberal dos governos de Cardoso. A linha de ruptura é observada por Cervo apenas no momento em que Lula abandona os mecanismos de inserção dependente baseados no neoliberalismo e no conceito de globalização assimétrica e passa a priorizar a autonomia do país. Em termo de política externa, essa ruptura significou uma 
priorização da cooperação sul-sul e da aproximação a parceiros não tradicionais, como os países do Oriente Médio, por exemplo.

Utilizando as categorias propostas por Hermann (1990) para análise de mudança em política externa, Miriam Saraiva (2013) argumenta que a ação internacional do governo Lula se diferenciou da de seu predecessor no que diz respeito tanto à dinâmica do processo decisório quanto à forma de inserção do Brasil no sistema internacional. Segundo a autora, a crise do paradigma global no interior do Ministério das Relações Exteriores nos anos 1990 levou ao estabelecimento de duas correntes de pensamento no Itamaraty: a institucionalista pragmática (ligada ao governo FHC) e a autonomista (ligada ao governo Lula).

Enquanto a corrente institucionalista pragmática, que vigorou durante $o$ governo FHC, atuava por meio do conceito de soberania compartilhada e de autonomia pela integração, a autonomista defendia projeção autossuficiente e proativa do Brasil no sistema internacional, por meio da defesa da reforma das instituições internacionais e da aproximação com países emergentes. De acordo com Miriam Saraiva (2013), com a ascensão da corrente autonomista no Itamaraty, novos atores foram incorporados ao processo de formulação e de execução da política externa brasileira, como, por exemplo, acadêmicos ligados ao Partido dos Trabalhadores (PT), o Foro de São Paulo e outras agências governamentais para além do Ministério das Relações Exteriores.

De acordo com Pinheiro (2010), a pluralização dos atores no processo de formulação e execução da PEB fez que novas redes de conexão interministerial fossem criadas a partir do governo Lula. Maria Regina Soares Lima (2005) destaca que, apesar de o Itamaraty ter conseguido manter relativa autonomia durante o governo Lula, a mudança na política externa brasileira ocorrida a partir de $2003 \mathrm{em}$ função de sua maior politização induziu à maior modernização dos arranjos existentes, de modo a levarem-se em conta novos atores e interesses domésticos, diversificando, assim, a pauta da PEB.

Miriam Saraiva (2013) faz diferenciação entre as nuanças de continuidade e de ruptura durante o primeiro e o segundo mandato da administração Lula. Segundo a autora, no primeiro mandato, as rupturas foram menos visíveis, as forças da tradição e da continuidade no Itamaraty evitaram forte clivagem em relação ao governo anterior, e ocorreram ajustes, ou seja, as mudanças foram restritas às prioridades e às intensidades das ações. No segundo mandato, entretanto, a ideia de mudança de 
programa aparece mais claramente, e a posição de apoio aos regimes internacionais clássicos adotada durante o governo de FHC cede lugar a um papel de promotor da reforma da governança global, fazendo que o Brasil se projetasse, internacionalmente, como player global.

Pesquisadores estrangeiros, como Sean Burges (2009), Riordan Roett (2011), Larry Rohter (2012) e Arlene Tickner (2012), diferentemente da maior parte dos acadêmicos brasileiros, ressaltam as continuidades entre as duas políticas externas e o legado da estabilidade política e econômica do governo FHC para o estabelecimento da política externa do governo Lula. Segundo Larry Rother (2012: 254), a herança mais positiva e emblemática de FHC para Lula foi a estabilidade política e econômica ${ }^{6}$. Dessa forma, o fato de o governo FHC ter trazido os militares para o controle civil e ter dado início ao processo de estabilização da economia por meio do controle inflacionário e orçamentário construiu as bases para que o Brasil se projetasse de maneira mais assertiva, internacionalmente, a partir de 2003.

De modo análogo, Riordan Roett (2011) argumenta que o Brasil emergiu, durante o governo Lula, como um player diplomático regional e global em função do legado de continuidade dos anos de governo de FHC. Segundo a análise de Roett (2011), foi na diplomacia de FHC que se iniciou o processo de intensificação dos esforços brasileiros de integração econômica e de presença do Brasil em grandes fóruns internacionais. Roett (2011:149-152) afirma que os oito anos do governo Lula promoveram mais continuidades do que rupturas em relação ao governo Cardoso e que, em sua opinião, Lula contou com a conjuntura externa bastante favorável; no entanto, segundo o autor, deve-se levar em conta que as realizações em termos de política externa dos oito anos de administração Lula só foram possíveis em razão da continuidade das políticas fundamentais de estabilização econômica iniciadas por seu antecessor, Fernando Henrique Cardoso.

A professora colombiana Arlene Tickner (2012) enfatiza a antiga tradição diplomática brasileira, ao argumentar que a estratégia para atingir papel mais ativo e proeminente no sistema internacional durante o governo Lula veio de forma pouco espetacular. Segundo Tickner (2012: 367-382), as principais características da PEB de Lula, como a lealdade às instituições internacionais, a resolução pacífica de conflitos, a busca do desenvolvimento, a defesa da soberania e da não intervenção, a busca por

\footnotetext{
${ }^{6}$ Tradução livre.
} 
autonomia e a obtenção de assento permanente no CSNU, são predicados históricos da diplomacia brasileira. Tickner (2012), ademais, destaca a importância do fim da hiperinflação e da consolidação da democracia durante os anos da gestão FHC para que a projeção internacional brasileira no governo Lula fosse possível.

De forma bastante objetiva, Sean Burges (2009), ao discorrer acerca das continuidades e das mudanças em política externa durante o primeiro mandato do governo Lula, defende o tema das continuidades e tenta indicar, ao menos provisoriamente, como a trajetória estabelecida por FHC persistiu. Segundo Burges (2009), apesar das diferentes prioridades políticas apresentadas no momento da mudança partidária no Brasil, em 2003ㄱ, a vitória de Lula trouxe poucas mudanças à política externa brasileira em razão, principalmente, da forte pressão dos mercados internacionais sobre o novo presidente eleito.

Por outro lado, Sean Burges (2009) ressalta algumas mudanças de tom e de estilo político implantadas no Ministério das Relações Exteriores do Brasil, a partir do início do governo Lula. As progressões e as nomeações da carreira diplomática, por exemplo, passaram a demonstrar maior ligação política; além disso, membros alheios ao corpo do serviço exterior brasileiro passaram a ocupar postos-chave no governo Lula, como Marco Aurélio Garcia, professor de História na UNICAMP, ex-secretário de relações internacionais do PT e um dos fundadores do Foro de São Paulo, nomeado, a partir de 2003, assessor especial de política externa da Presidência e denominado, pela opinião pública, chanceler não oficial do governo para assuntos de América do Sul.

De acordo com Pinheiro (2010), a presença de uma assessoria especial em relações internacionais junto à Presidência da República diminuiu a hegemonia das funções de formulação e concepção de política externa, antes exclusivas à corporação diplomática. Juntamente com a posse de Marco Aurélio Garcia, a nomeação do novo secretário-geral do Itamaraty, embaixador Samuel Pinheiro Guimarães, também identificado com a história da política externa da esquerda no Brasil, fez que prioridade fosse dada aos princípios de solidariedade sul-americana e de cooperação entre os países em desenvolvimento.

\footnotetext{
${ }^{7}$ Segundo Burges (2009), a prioridade política do governo Cardoso baseava-se na reforma estrutural da política econômica e da sociedade. O governo Lula, por outro lado, tinha objetivo prático e imediato, $\mathrm{o}$ de garantir a cada criança, ao menos, três refeições diárias.
} 
Sean Burges (2009) defende em sua análise que, com a ascensão de Lula, representante da esquerda e da classe operária brasileira, ocorreu intensa mudança de estilo na forma de governar no Brasil. Segundo o autor, implantou-se, a partir de então, o que ele denominou de "politização da PEB", que passou do imperativo fundado em bases econômicas de FHC para o baseado em temas políticos de Lula. Novos objetivos, consequentemente, foram planejados, como a liderança do denominado "sul global" (em comparação à atitude mais reservada de FHC em relação às ambições brasileiras por poder). Burges (2009), no entanto, é bastante crítico em relação à capacidade de liderança brasileira; segundo o autor, o Brasil da era Lula não conseguiu, em termos tanto políticos como econômicos, sustentar o desenvolvimento dos países vizinhos, não sendo capaz de assumir os custos de liderança a que se predispôs inicialmente.

A tabela 1, abaixo, é um ensaio de diferenciação entre os anos de governo FHC e os de Lula no que tange temas centrais à política externa brasileira ${ }^{8}$.

Tabela 1: Temáticas e abordagens - PEB Cardoso e PEB Lula

\begin{tabular}{|c|c|c|}
\hline & PEB Cardoso & PEB Lula \\
\hline $\begin{array}{l}\text { 1. Conselho de } \\
\text { Segurança da ONU }\end{array}$ & $\begin{array}{l}\text { Manteve o Brasil em condição } \\
\text { de candidato não insistente a } \\
\text { uma cadeira permanente no } \\
\text { CSNU. }\end{array}$ & $\begin{array}{l}\text { Estratégia de alianças com outras } \\
\text { potências médias e economias } \\
\text { emergentes. Prioridade à } \\
\text { conquista de cadeira permanente } \\
\text { no CSNU. }\end{array}$ \\
\hline $\begin{array}{l}\text { 2. FMI e } \\
\text { condicionalidades }\end{array}$ & $\begin{array}{l}\text { Abordagem não ideológica das } \\
\text { relações com o FMI. }\end{array}$ & $\begin{array}{l}\mathrm{O} \text { Brasil encaminhou } \mathrm{o} \\
\text { pagamento integral e passou a } \\
\text { ser credor. }\end{array}$ \\
\hline $\begin{array}{l}\text { 3. Liderança } \\
\text { brasileira }\end{array}$ & $\begin{array}{l}\text { O papel de líder do Brasil era } \\
\text { discreto, considerado por FHC } \\
\text { como resultado da preeminência } \\
\text { econômica do país e deveria ser } \\
\text { limitado à região sul-americana } \\
\text { em vista da limitação de } \\
\text { recursos disponíveis. }\end{array}$ & $\begin{array}{l}\text { Um dos principais objetivos } \\
\text { políticos do Brasil. O Presidente } \\
\text { Lula tornou a busca por poder } \\
\text { global o objetivo explícito de sua } \\
\text { política externa }{ }^{9} \text {. }\end{array}$ \\
\hline
\end{tabular}

${ }^{8}$ Elaboração baseada em Almeida (2003), Cardoso (2012) e Tickner (2012).

${ }^{9}$ TICKNER, 2012. 


\begin{tabular}{|c|c|c|}
\hline 4. América do Sul & $\begin{array}{l}\text { Algumas iniciativas com relação } \\
\text { à América do Sul merecem } \\
\text { destaque, como a IIRSA e a } \\
\text { assinatura do Protocolo de Ouro } \\
\text { Preto no MERCOSUL. Além } \\
\text { disso, o Brasil mediou o conflito } \\
\text { Peru-Equador, enfatizando que } \\
\text { as disputas na região deveriam } \\
\text { ser resolvidas sem a intervenção } \\
\text { de atores externos. Ademais, } \\
\text { após crise interna no Paraguai, } \\
\text { articulou-se a assinatura do } \\
\text { Protocolo de Ushuaia no âmbito } \\
\text { do MERCOSUL. }\end{array}$ & $\begin{array}{l}\text { Lula não apenas confirmou que } \\
\text { essas relações eram estratégicas } \\
\text { como também tomou diversas } \\
\text { iniciativas políticas para traduzir } \\
\text { a retórica em realidade. A } \\
\text { América do Sul foi vista como } \\
\text { plataforma para a inserção } \\
\text { internacional do Brasil. }\end{array}$ \\
\hline 5. MERCOSUL & $\begin{array}{l}\text { O MERCOSUL era visto por } \\
\text { FHC como base possível para a } \\
\text { integração da região da América } \\
\text { do Sul com o mundo. Os temas } \\
\text { econômicos e comerciais } \\
\text { tiveram prioridade na agenda do } \\
\text { MERCOSUL. }\end{array}$ & $\begin{array}{l}\text { O MERCOSUL constituiu } \\
\text { prioridade da diplomacia do } \\
\text { governo Lula. Os temas sociais e } \\
\text { políticos assumiram precedência } \\
\text { aos temas econômicos e } \\
\text { comerciais. Passou-se a dar } \\
\text { maior importância aos aspectos } \\
\text { não diretamente comerciais da } \\
\text { integração. }\end{array}$ \\
\hline 6. Argentina & $\begin{array}{l}\text { O país platino sempre foi um } \\
\text { parceiro estratégico para FHC. }\end{array}$ & $\begin{array}{l}\text { O Brasil de Lula buscou } \\
\text { posições comuns com o país } \\
\text { platino. }\end{array}$ \\
\hline 7. Europa & $\begin{array}{l}\text { FHC via a Europa como o } \\
\text { principal parceiro do Brasil. }\end{array}$ & $\begin{array}{l}\text { Lula acredita em papel político } \\
\text { compensatório a ser } \\
\text { desempenhado pela Europa, em } \\
\text { alianças estratégicas contra o } \\
\text { unilateralismo dos EUA. }\end{array}$ \\
\hline 8. Estados Unidos & Reciprocidade moderada. & $\begin{array}{l}\text { Lula passou a tratar os EUA na } \\
\text { base da estrita reciprocidade. }\end{array}$ \\
\hline 9. Oriente Médio & $\begin{array}{l}\text { Posição de FHC: "É cedo } \\
\text { demais para um país com tantos } \\
\text { problemas internos de pobreza e } \\
\text { de desenvolvimento } \\
\text { insuficiente, como o Brasil, } \\
\text { aventurar-se por esses mares } \\
\text { bravios". (CARDOSO, } \\
\text { 2012:628) }\end{array}$ & $\begin{array}{l}\text { "Incorporar às discussões acerca } \\
\text { da situação no Oriente Médio os } \\
\text { países em desenvolvimento, } \\
\text { como o Brasil, daria mais } \\
\text { legitimidade e traria novas ideias } \\
\text { às conversações de paz" } \\
\text { (AMORIM, 2009) }\end{array}$ \\
\hline
\end{tabular}

\footnotetext{
${ }^{10}$ Discurso proferido pelo Ministro Celso Amorim durante a Conferência Internacional em apoio à economia palestina para a reconstrução de Gaza. Sharm el-Sheik, 2 de março de 2009.
} 


\subsection{Posições históricas do Partido dos Trabalhadores em política externa}

Analistas de política externa, como Paulo Roberto de Almeida (2003; 2004), Miriam Gomes Saraiva (2010), Tatiana Berringer (2013) e KjeldJakobsen (2013), identificam pontos de convergência da plataforma programática do Partido dos Trabalhadores (PT) com as principais linhas da política externa do governo Lula. Paulo Roberto de Almeida (2004) é assertivo, ao afirmar que a PEB do governo Lula é a vertente da atividade governamental que mais reflete as proposições históricas e tradicionais do PT e que, na arena internacional, o governo do Presidente Lula mais se assemelhou ao discurso do Partido dos Trabalhadores.

Desde sua primeira disputa presidencial, em 1989, uma das principais características do candidato Luiz Inácio Lula da Silva foi sua identificação com os povos da América Latina. À época, constituiu-se no país a denominada Frente Brasil Popular, formada por vários partidos de esquerda que apoiavam o candidato do PT e que prometia adotar atitude anti-imperialista, prestando solidariedade às lutas em defesa da autodeterminação, da soberania nacional e de movimentos em favor da luta dos trabalhadores pela democracia, pelo progresso social e pelo socialismo (ALMEIDA, 2003). Coadunam-se com a política externa do governo Lula, dessa maneira, os pontos iniciais da plataforma de política externa do PT, entre os quais se destacam a independência nacional, a atitude contrária à dominação imperialista, a política externa independente, o respeito à autodeterminação dos povos e a solidariedade aos povos da América Latina, diferenciando-se, dessa forma, em larga maneira, da política externa de seu predecessor, o presidente FHC.

Por iniciativa de Lula, então candidato presidencial, estabeleceu-se em São Paulo um foro de partidos de esquerda na América Latina ${ }^{11}$ - o Foro de São Paulo ${ }^{12}$ que se consolidou como reunião periódica de formações progressistas da região, contrárias às políticas neoliberais conservadoras de estabilização econômica. Em sua primeira declaração pública, em 1991, o Foro de São Paulo explicitou a vontade do PT e de outras formações políticas de esquerda da América Latina de opor-se à "Iniciativa das Américas", do então Presidente Bush, classificada pelo Foro como

\footnotetext{
${ }^{11}$ Fazem parte do Foro de São Paulo 26 países da América Latina e 106 partidos de esquerda.

${ }^{12}$ O Foro de São Paulo constituiu-se em 1990, quando partidos da América Latina e do Caribe se reuniram a convite do Partido dos Trabalhadores (PT, Brasil), com o objetivo de debater a nova conjuntura internacional após a queda do Muro de Berlim e as consequências das políticas neoliberais pela maioria dos governos da região. A proposta principal foi discutir uma alternativa popular e democrática ao neoliberalismo.
} 
modelo de integração imperialista (ALMEIDA, 2003). A tabela 2 apresenta os países e os partidos políticos de esquerda que compõem o Foro de São Paulo ${ }^{13}$.

Tabela 2: Países e partidos políticos componentes do Foro de São Paulo

\begin{tabular}{|l|l|}
\hline País & Partido Político \\
\hline Argentina & $\begin{array}{l}\text { Frente Grande } \\
\text { Frente Transversal Nacional y Popular } \\
\text { Movimento Evita } \\
\text { Movimento Libres delSur } \\
\text { Partido Comunista } \\
\text { Partido Comunista - Congreso Extraordinário } \\
\text { Partido Humanista } \\
\text { Partido Intransigente } \\
\text { Partido Obrero Revolucionário Posadista } \\
\text { Partido Socialista } \\
\text { Partido Solidario } \\
\text { Union de Militantes por el Socialismo }\end{array}$ \\
\hline Aruba & $\begin{array}{l}\text { Partido Rede Democratica } \\
\text { Barbados }\end{array}$ \\
\hline Bolívia & $\begin{array}{l}\text { Partido del Empoderamiento del Pueblo } \\
\text { Movimiento al Socialismo } \\
\text { Partido Comunista de Bolivia }\end{array}$ \\
\hline Brasil & $\begin{array}{l}\text { Partido Democrático Trabalhista } \\
\text { Partido Comunista do Brasil } \\
\text { Partido Comunista Brasileiro } \\
\text { Partido Pátria Livre } \\
\text { Partido Popular Socialista } \\
\text { Partido Socialista Brasileiro } \\
\text { Partido dos Trabalhadores }\end{array}$ \\
\hline Chile & $\begin{array}{l}\text { Izquierda Cristiana } \\
\text { Movimiento Amplio Social } \\
\text { Movimiento de Izquierda Revolucionária } \\
\text { Partido Comunista } \\
\text { Partido Humanista } \\
\text { Partido Socialista } \\
\text { Partido del Socialismo Allendista } \\
\text { Presentes porat el Socialismo }\end{array}$ \\
\hline
\end{tabular}

${ }^{13}$ Elaboração baseada no site oficial do Foro de São Paulo <http://forodesaopaulo.org > 


\begin{tabular}{|c|c|}
\hline Costa Rica & $\begin{array}{l}\text { Partido Frente Amplio } \\
\text { Partido Vanguardia Popular }\end{array}$ \\
\hline Cuba & Partido Comunista de Cuba \\
\hline Curazao & Partido Pueblo Soberano \\
\hline Ecuador & $\begin{array}{l}\text { Movimiento de Unidad Plurinacional Pachakutik } \\
\text { Movimiento Alianza PAIS } \\
\text { Movimiento Popular Democrático } \\
\text { Partido Comunista del Ecuador } \\
\text { Partido Comunista Marxista - Leninista del Ecuador } \\
\text { Partido Socialista - Frente Amplia }\end{array}$ \\
\hline El Salvador & Frente Farabundo Martí para la Liberación Nacional \\
\hline Guatemala & $\begin{array}{l}\text { Alianza Nueva Nación } \\
\text { Movimiento Político Winaq } \\
\text { Unidad Revolucionaria Nacional Guatemalteca }\end{array}$ \\
\hline Haiti & Organización del Pueblo en Lucha \\
\hline Honduras & $\begin{array}{l}\text { Frente Nacional de Resistencia Popular } \\
\text { Partido Libertad y Refundación }\end{array}$ \\
\hline Martinica & $\begin{array}{l}\text { Partido Comunista por la Independência y el Socialismo } \\
\text { Consejo Nacional de Comités Populares }\end{array}$ \\
\hline México & $\begin{array}{l}\text { Partido de los Comunistas Mexicanos } \\
\text { Partido Comunista de Mexico } \\
\text { Partido de la Revolución Democratica } \\
\text { Partido del Trabajo }\end{array}$ \\
\hline Nicarágua & Frente Sandinista de Liberación Nacional \\
\hline Panamá & $\begin{array}{l}\text { Partido del Pueblo } \\
\text { Partido Revolucionário Democrático }\end{array}$ \\
\hline Paraguay & $\begin{array}{l}\text { Frente Guasú } \\
\text { Partido Comunista Paraguayo } \\
\text { Partido Convergencia Popular Socialista } \\
\text { Partido del Movimiento Patriótico Popular } \\
\text { Partido del Movimiento al Socialismo } \\
\text { Partido País Solidário } \\
\text { Partido de la Participación Ciudadana } \\
\text { Partido Popular Tekojoja }\end{array}$ \\
\hline Peru & $\begin{array}{l}\text { Partido Comunista del Peru } \\
\text { Partido Comunista Peruano } \\
\text { Partido Nacionalista del Peru } \\
\text { Partido del Pueblo } \\
\text { Partido Socialista del Perú }\end{array}$ \\
\hline Puerto Rico & $\begin{array}{l}\text { Frente Socialista } \\
\text { Movimento Independentista Nacional Hortosiano } \\
\text { Partido Nacionalista de Puerto Rico }\end{array}$ \\
\hline
\end{tabular}




\begin{tabular}{|l|l|}
\hline República Dominicana & $\begin{array}{l}\text { Alianza por la Democracia } \\
\text { Fuerza por la Revolución } \\
\text { Movimiento Izquierda Unida } \\
\text { Partido Alternativa Revolucionária } \\
\text { Partido Comunista del Trabajo } \\
\text { Partido de la Liberación Dominicana } \\
\text { Partido de los Trabajadores Dominicanos } \\
\text { Partido Revolucionário Dominicano }\end{array}$ \\
\hline Trinidad y Tobago & Movimiento por la Justicia Social \\
\hline Uruguay & $\begin{array}{l}\text { Asamblea Uruguay } \\
\text { Compromiso Frenteamplista } \\
\text { Frente Amplio } \\
\text { Movimiento 26 de março } \\
\text { Movimiento de Liberación Nacional Tupamaros } \\
\text { Movimiento de Participación Popular } \\
\text { Movimiento Popular Frenteamplista } \\
\text { Partido Comunista del Uruguay } \\
\text { Partido Obrero Revolucionário Troskista - Posadista } \\
\text { Partido por la Victoria del Pueblo } \\
\text { Partido Socialista de los Trabajadores } \\
\text { Partido Socialista del Uruguay } \\
\text { Vertiente Artiguista }\end{array}$ \\
\hline Venezuela & $\begin{array}{l}\text { Liga Socialista } \\
\text { Movimiento Electoral del Pueblo } \\
\text { Partido Comunista de Venezuela } \\
\text { Partido Socialista Unificado de Venezuela } \\
\text { Patria para todos }\end{array}$ \\
\hline
\end{tabular}

Os programas da plataforma presidencial do PT em 1994 e em 2002 destacaram o MERCOSUL e o fortalecimento das relações com o Sul global como temas principais da nova PEB. Propôs-se, ademais, a substituição do conceito de América Latina pelo de América do Sul, tendo em vista que a América Central e o Caribe, assim como o México, eram identificados como áreas de influência direta dos Estados Unidos. Destaca-se, entre as diretrizes da plataforma programática do PT, o $12^{\circ}$ ponto de acordo com o qual se evoca a presença soberana do Brasil no mundo. A intenção do Partido dos Trabalhadores, nesse sentido, foi a de pautar a atuação internacional do Brasil com o objetivo de reformar as relações desiguais e injustas entre os países no sistema internacional (ALMEIDA, 2003).

Segundo Jakobsen (2013), uma das principais críticas dos opositores da PEB do governo Lula é a afirmação de que, entre 2003 e 2010, impôs-se a visão particular do PT sobre as decisões acerca da atuação internacional do Brasil, rompendo com o consenso construído ao longo dos anos. Assim, a ideologização e a partidarização da 
política externa brasileira teriam sido prejudiciais à política exterior do Estado brasileiro, tradicionalmente operacionalizada de forma previsível pelos quadros do Itamaraty, rompendo o consenso construído historicamente, segundo o qual a política internacional do Brasil é uma política de Estado e não de governo. Ricupero (2010) chega a afirmar, nesse sentido, que a nomeação de assessor para assuntos de política externa para a Presidência da República pelo governo Lula fez que surgisse, no Brasil, caso sui generis de diplomacia paralela do PT, prejudicial, ao seu entender, à tradicional política de Estado brasileira.

Percebe-se, no entanto, que, apesar de diversos pontos da plataforma programática do PT terem sido efetivamente transformados em grandes linhas da política externa do governo Lula, como, por exemplo, o direcionamento da PEB para a cooperação sul-sul, a diplomacia brasileira preservou, em questões essenciais, seu insulamento burocrático e o controle principal da gestão da política externa brasileira, mantendo-se o que Cervo $(2010 ; 2012)$ conceituou como "acumulado histórico da diplomacia brasileira". A herança de estabilização política e econômica dos oito anos de administração FHC, ademais, serviu como base de continuidade para que novos objetivos de política externa fossem praticados a partir do governo Lula.

\subsection{Política Externa durante o governo Lula: características gerais}

Historiadores e analistas de política externa convergem opiniões acerca da permanência, durante os dois mandatos do Presidente Lula, de cinco características fundamentais na condução da política externa brasileira: nacionalismo; multilateralismo estratégico; universalismo; formação de alianças e cooperação sulsul; busca de liderança regional ${ }^{14}$.

No que diz respeito à atitude nacionalista da política externa brasileira, percebeu-se a intenção dos formuladores e dos executores da PEB em colocar a ação diplomática como instrumento para a promoção do desenvolvimento social e econômico do país (SOUTO MAIOR; 2003; AMORIM, 2010; PINHEIRO, 2010). Alguns autores, como Pinheiro (2010), afirmam que a inclusão social e a formação de mercado de massas expressivo se constituíram em um dos principais pilares da PEB. Consequentemente, a diplomacia do governo Lula apresentou estilo assertivo em

\footnotetext{
${ }^{14}$ SOUTO MAIOR, 2003; DE ALMEIDA; 2004; AMADO CERVO, 2004; SARAIVA, 2004; LESSA, 2010; MEZA, 2010; AMORIM, 2010; PINHEIRO, 2010; LIMA, 2005.
} 
torno da defesa da soberania nacional e dos interesses do país, com o objetivo duplo de posicionar o Brasil no círculo das potências emergentes e de melhorar as condições sociais e econômicas da população pobre (MEZA, 2010; DE ALMEIDA, 2004). Pode-se afirmar que o governo Lula foi bem-sucedido em sua empreitada de implantar ambiciosa reforma social no país, o que conferiu aprovação internacional ao país e projetou o Brasil internacionalmente (ROETT, 2011).

A defesa do multilateralismo estratégico como característica da PEB sempre fez parte do que Cervo (2004) denomina de "acumulado histórico da diplomacia brasileira". Segundo o historiador, durante o governo Lula, o Brasil utilizou-se do conceito de "multilateralismo da reciprocidade", cujos pressupostos incluem a existência de regras que governam a ordem internacional, a formulação conjunta de normas (de modo que não favoreçam os interesses de uns em detrimento de outros) e, por fim, a defesa da ordem ideal como sendo a ordem multilateral. Percebe-se nos discursos dos principais policymakers do governo Lula que o multilateralismo brasileiro veio acrescido de visão estratégica, cujo objetivo foi dar maior projeção à imagem brasileira de global player a fim de que o Brasil se legitimasse como ator protagonista da reforma da governança global (AMORIM, 2010).

Segundo Raúl Bernal-Meza (2010), Lula utilizou-se do multilateralismo em política externa para frear o poder dos Estados Unidos e reconhecer novos centros de poder emergentes. A defesa ativa do multilateralismo durante a PEB de Lula explicase, portanto, pelo projeto político maior de reforçar a capacidade de intervenção do Brasil no mundo e na vontade explicitamente declarada de ocupar cadeira permanente no Conselho de Segurança das Nações Unidas (ALMEIDA, 2004). Lessa (2010) corrobora esse argumento, ao afirmar que, durante a PEB de Lula, o Brasil teve chances de atuar como protagonista no debate em relação à legitimidade da política internacional contemporânea e à necessidade de reformar as instituições multilaterais.

O universalismo pode ser considerado a principal fundação da política externa do governo Lula e sua principal diferenciação em relação ao governo anterior. Cervo (2004; 2010) e Saraiva (2004) destacam a firme intenção de Lula em recuperar os espaços perdidos na África, na Ásia e no Oriente Médio. O objetivo do universalismo da PEB foi ambicioso: intencionou-se produzir contrapeso à histórica dependência diante dos Estados Unidos e orientar o Brasil a ter relações com todos os países do globo. Em termos materiais, o universalismo foi implantado pela expansão dos quadros diplomáticos do Ministério das Relações Exteriores e pelo aumento em mais 
de $30 \%$ do número de países com os quais o Brasil possuía representação diplomática (CERVO, 2010; 2012).

Antonio Carlos Lessa (2010) pondera, no entanto, que, para além das alianças com países considerados como novos eixos dinâmicos mundiais, a PEB do governo Lula empenhou-se em estreitar o relacionamento com tradicionais parceiros, como a União Europeia, os Estados Unidos e o Japão. Para tanto, a diplomacia brasileira utilizou-se de três modos de atuação principais: firme ação em contextos multilaterais, reconstrução do universalismo geográfico e revalorização de contatos bilaterais. $\mathrm{O}$ conceito de parcerias estratégicas, instrumento de diplomacias comprometidas com o fundamento universalista, no entanto, tendeu a ser exageradamente vulgarizado durante o governo Lula, o que gerou "espetacularização" da diplomacia brasileira e excesso de utilização do termo parcerias estratégicas (LESSA, 2010).

Entre os novos projetos da PEB a partir do governo Lula, reveste-se de grande importância a construção de coalizões entre países similares e a cooperação denominada "sul-sul". Segundo Cervo (2010; 2012), a PEB utilizou-se de estratégia integracionista para estabelecer e consolidar rede de alianças direcionada para o sul global, cujos objetivos foram democratizar a ordem internacional e criar contrapoder. Miriam Gomes Saraiva (2013) observa que essa tendência de construção de novas coalizões de países emergentes se iniciou no primeiro mandato do governo Lula e consolidou-se, efetivamente, apenas no segundo mandato. Iniciativas, como a Cúpula América do Sul - Países Árabes (ASPA), a Cúpula América do Sul - África (ASA), o Fórum Índia, Brasil e África do Sul (IBAS), o grupo de coordenação de questões ambientais, formado por Brasil, África do Sul, Índia e China (BASIC), e o mecanismo de concertação político-diplomático formado por Brasil, Rússia, Índia, China e África do Sul (BRICS), são exemplos da profusão de coalizões sul-sul surgidas, em sua maioria, durante o primeiro mandato do governo Lula e consolidadas no segundo período de governo.

A questão da liderança do Brasil no contexto regional do MERCOSUL, da América do Sul e, posteriormente, da América Latina pode ser considerada um dos eixos primários de atuação da política externa brasileira durante o governo Lula e um dos temas mais polêmicos de atuação da PEB nesse período. O discurso de posse do Presidente Lula em sessão inaugural no Congresso Nacional demonstra a primazia da PEB para as questões regionais: "A grande prioridade da política externa durante meu Governo será a construção de uma América do Sul politicamente estável, próspera e 
unida com base em ideais democráticos e de justiça social”. Como ressaltado anteriormente, o projeto de PEB direcionado para a América do Sul é parte do programa maior de governo do PT e, durante os dois mandatos do governo Lula, foi implantado de forma gradual, dando-se prioridade, respectivamente, à integração do MERCOSUL, da América do Sul e da América Latina.

Inicialmente, a PEB de Lula voltou-se, insistentemente, ao MERCOSUL, pois considerava o bloco regional como ponto de partida para a conformação de um bloco sul-americano e instrumento para reforçar o poder de barganha do Brasil internacionalmente (CERVO, 2004; 2010). Passou-se, a partir de então, a dar maior importância a aspectos não comerciais do MERCOSUL e, de forma menos reservada do que na gestão FHC, a PEB de Lula passou a adotar discurso político de potência regional, propondo-se liderar a integração sul-americana de maneira não autoritária e tratar das assimetrias econômicas e sociais na região (SOUTO MAIOR, 2003; MEZA, 2010; SARAIVA, 2010). A intensificação das trocas de visitas presidenciais, logo nos primeiros anos de governo, reflete a prioridade regional de forma pragmática: em apenas oito meses, o Presidente Lula recebeu a visita de todos os presidentes da América do Sul e, em dois anos, visitou todos os países da região (AMORIM, 2010).

De modo pouco reservado, atores centrais da formulação e da execução da política externa brasileira, como Marco Aurélio Garcia e Samuel Pinheiro Guimarães, não se constrangeram em posicionar o Brasil, claramente, como líder na América do Sul (BURGES, 2009). De acordo com o discurso oficial, a intenção brasileira não foi buscar a liderança no contexto regional por imposição, mas instigar a configuração de uma ordem internacional mutuamente benéfica. Segundo Amorim (2010) e Roett (2011), as iniciativas brasileiras de liderança não podem ser analisadas como antiEUA, mas como um processo pró-América Latina e Caribe. Opiniões divergem nesse sentido. Cervo (2010), por exemplo, acredita que a diplomacia brasileira considera o contexto sul-americano como instrumento para reforçar seu poder de barganha internacional.

Apreciações também dissentem entre analistas brasileiros e estrangeiros de política externa brasileira acerca da disposição do governo Lula em arcar com os custos da liderança do processo de integração sul-americano. Segundo Saraiva (2010) e Amorim (2010), durante o governo Lula, observou-se disposição e capacidade da administração pública brasileira em arcar com custos do processo de integração sulamericano. Essa opinião é divergente da de Burges (2009), segundo a qual o Brasil da 
era Lula não foi politicamente capaz de sustentar o desenvolvimento dos países vizinhos, sugerindo, assim, que o país não estava disposto a arcar com os custos de uma liderança potencial na América do Sul.

\subsection{Objetivos da Política Externa Brasileira durante os anos Lula}

Ao examinar os discursos dos principais formuladores e executores da política externa do governo Lula, percebe-se que o ativismo tinha objetivos bem determinados: garantir a presença soberana do Brasil no mundo; reformar a governança global; conquistar assento permanente no Conselho de Segurança das Nações Unidas; liberalizar os mercados agrícolas mundiais; expandir o comércio internacional do Brasil.

No que diz respeito à incorporação assertiva do Brasil na cena internacional, pode-se afirmar que a meta de reforçar a capacidade de intervenção do Brasil no mundo foi implantada por meio da corrente mais nacionalista e autonomista no Itamaraty, a qual buscou a promoção autônoma do Brasil na ordem internacional (SARAIVA, 2013; LESSA, 2010). A garantia da presença soberana do Brasil no mundo pode ser considerada o objetivo geral da política externa. Pôde-se perceber que, ao longo dos oito anos de mandato do Presidente Lula, o Brasil, gradualmente, ganhou voz em grandes fóruns e regimes internacionais, expandindo suas parcerias estratégicas e projetando-se, de forma mais assertiva, em temas até então não priorizados pela PEB, como a reforma da governança global, a promoção de assistência humanitária internacional, projetos de cooperação sul-sul e a mediação de conflitos internacionais no Oriente Médio.

A reforma da governança global é considerada por grande parte dos analistas de política externa como o principal objetivo político da diplomacia brasileira durante o governo Lula, o que gerou desdobramentos de posições enfáticas do Brasil, como a busca por um assento permanente no CSNU e a criação de coalizões de países com propostas de reforma desse Conselho. Durante os dois mandatos do governo Lula, o Brasil buscou maior democratização das relações internacionais em fóruns internacionais, tentando reforçar seu poder para influir no ordenamento global e reivindicando atuação como ator importante no debate acerca do grau de legitimidade da política internacional contemporânea (LESSA, 2010; CERVO, 2012). 
Por diversas vezes, o chanceler Celso Amorim teceu diagnóstico acerca da situação de instituições políticas globais que, segundo ele, encontram-se obsoletas. De acordo com Amorim (2010), por exemplo, as Nações Unidas precisam de reforma para que sua legitimidade e eficiência sejam preservadas. A estratégia de construção de coalizões entre países em desenvolvimento é, consequentemente, método planejado pela política externa brasileira para que o país se engaje na reforma da governança global, com o objetivo de fazer que as instituições internacionais se tornem mais justas e democráticas. A reforma da governança global visa, dessa maneira, ampliar os espaços para a atuação internacional do país (SARAIVA, 2013).

A busca por assento permanente para o Brasil no Conselho de Segurança das Nações Unidas é o objetivo específico mais importante da PEB e, também, o mais antigo. Em entrevista coletiva concedida no Palácio do Planalto, em 29 de abril de 2005, em seu primeiro mandato, o Presidente Lula afirmou:

O Brasil já era para estar no Conselho de Segurança desde 1945, quando foi criada a ONU. O Brasil não entrou, o Brasil defende a democratização das Nações Unidas, defende, sobretudo, a democratização do Conselho de Segurança, defende a participação de representações por continente, pela África, que pode ter dois, pela América do Sul, pela Ásia, e o Brasil reivindica para si essa vaga, por ser o maior país da América do Sul e da América Latina, por ser um país de maior número de habitantes, o país de maior extensão territorial, então, temos o direito de reivindicar. Estamos reivindicando.

Diferentemente de Fernando Henrique Cardoso, que possuía estilo mais reservado e contido acerca das ambições brasileiras a um assento permanente no Conselho de Segurança das Nações Unidas (CSNU), o Presidente Lula atribuiu, de forma bastante direta, grande prioridade à obtenção de assento permanente em um Conselho de Segurança reformado (CERVO, 2004; ALMEIDA, 2004). Acadêmicos e diplomatas divergem quanto às ações implantadas pela diplomacia brasileira para atingir essa meta. Enquanto, para Lessa (2010), o objetivo de parte expressiva das mudanças na PEB da era Lula foi a conquista de um assento permanente no CSNU, para Amorim (2010), as ações tomadas pela diplomacia brasileira não foram condicionadas pelo objetivo central de tornar-se membro do CSNU, pois, segundo o chanceler do período Lula, o Brasil intencionou, antes, contribuir para a paz e para a segurança mundial do que servir a seus próprios interesses. 
As figuras $1^{15}$ e $2^{16}$, abaixo, têm por intenção fazer breve análise comparativa acerca dos objetivos, das estratégias e dos métodos de implantação da PEB do governo Lula, conforme a interpretação de dois dos principais analistas de política externa do Brasil, Antonio Carlos Lessa e Amado Luiz Cervo, que dialogam entre si:

Figura 1: PEB Lula - objetivos, estratégias e métodos de implantação (LESSA, 2010)

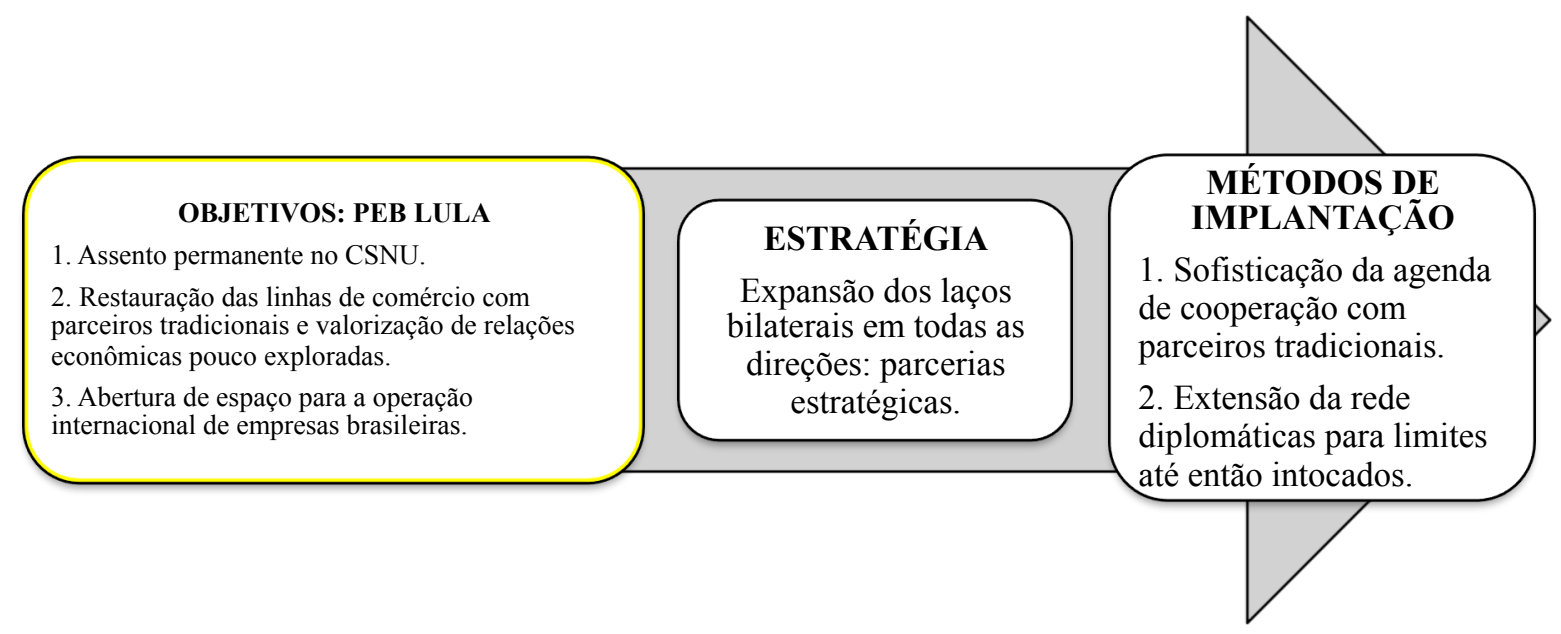

Figura 2: PEB Lula - objetivos, estratégias e métodos de implantação (CERVO, 2012)

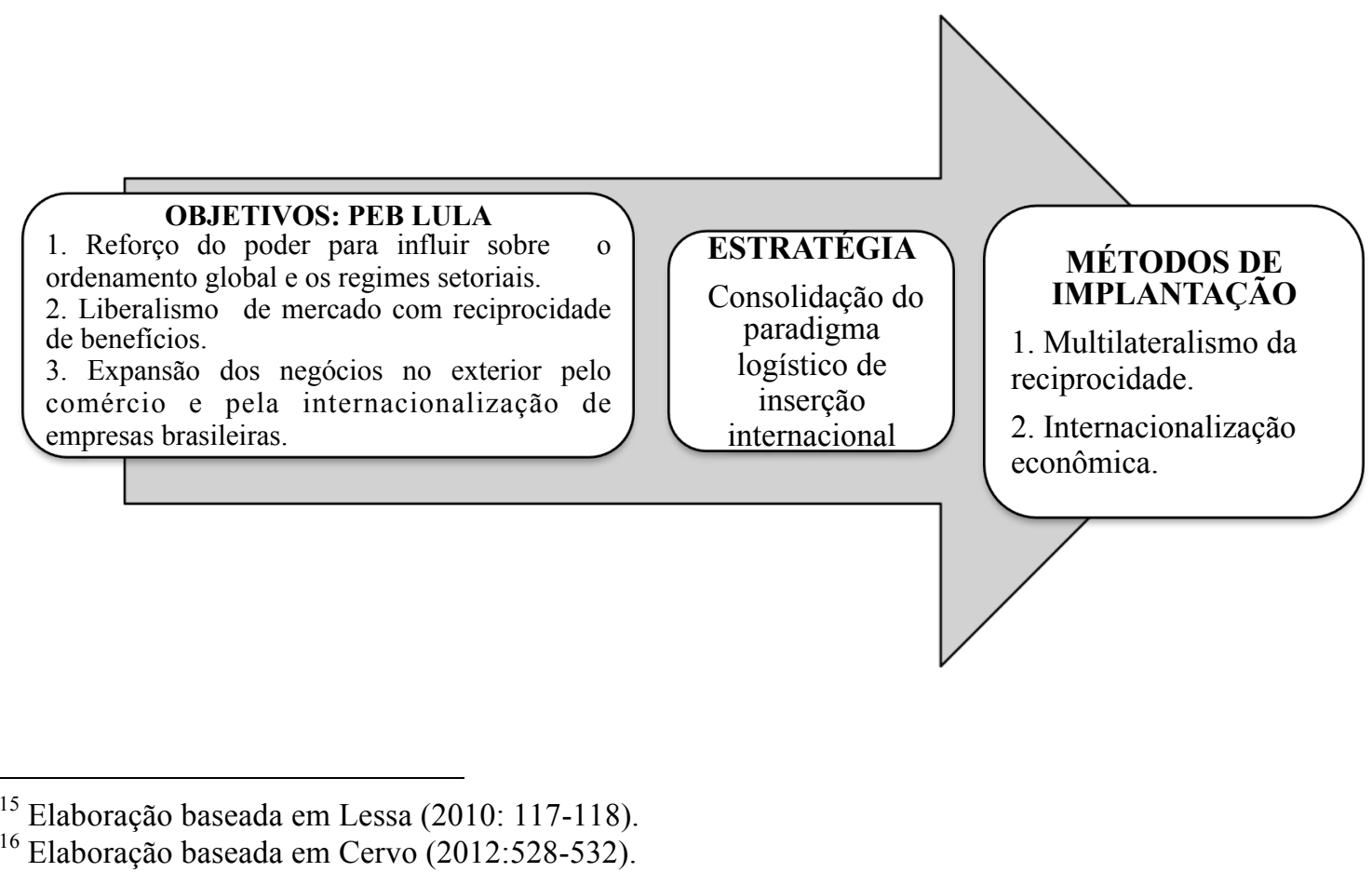

\footnotetext{
${ }^{15}$ Elaboração baseada em Lessa (2010: 117-118).

${ }^{16}$ Elaboração baseada em Cervo (2012:528-532).
} 
Quanto aos objetivos econômicos e comerciais da PEB, o Brasil deslocou-se no contexto internacional, durante o governo Lula, em busca de duas principais metas: liberalização dos mercados agrícolas com o fim dos subsídios e busca de novas rotas comerciais para nova geografia econômica para o país. Segundo Cervo (2010; 2012), o Brasil moveu-se na esfera econômica multilateral, com o objetivo de tornar as regras do comércio internacional mais justas, tentando garantir a reciprocidade de benefícios entre ricos e emergentes. A criação do G-20 Comercial no âmbito da Organização Mundial do Comércio (OMC), em 2003, em Cancun reflete o objetivo de levar a dimensão do desenvolvimento e da justiça às negociações comerciais. Ressalta-se, por fim, a dimensão econômica da PEB, que buscou novas rotas comerciais para construir o que Celso Amorim (2010) denominou de nova geografia econômica, ou seja, oportunidades de comércio sul-sul, visando ao aumento dos saldos positivos da balança comercial brasileira.

\subsection{Métodos de implantação dos objetivos da PEB de Lula}

Os métodos de implantação da nova política externa empregados pela diplomacia brasileira, para atingir os objetivos propostos, variaram de acordo com as diferentes análises existentes na literatura, mas podem ser resumidos em quatro principais: impulso da cooperação sul-sul e da formação de novas coalizões e parcerias; busca de agenda de cooperação com parceiros tradicionais; multilateralismo da reciprocidade; internacionalização da economia brasileira. A figura 3 sintetiza, de acordo com a literatura analisada, as principais características, objetivos e métodos de implantação da Política Externa do governo Lula ${ }^{17}$ :

\footnotetext{
${ }^{17}$ Elaboração própria.
} 
Figura 3: Características, objetivos e métodos de implantação da Política Externa de Lula

\section{CARACTERÍSTICAS \\ 1.Nacionalismo. \\ 2. Multilateralismo estratégico. \\ 3. Universalismo. \\ 4. Formação de alianças. \\ 5. Liderança regional}

\section{OBJETIVOS}

1. Garantir a presença soberana do Brasil.

2. Reforma da governança global.

3.Conquista de assento permanente no CSNU.

4. Liberalização de mercados.

5. Expansão do comércio internacional.

\section{METODOLOGIA DE IMPLANTAÇÃ̃O}

1. Agenda de cooperação com parceiros tradicionais.

2. Impulso da cooperação sul-sul.

3. Multilateralismo da reciprocidade.

4. Internacionalização da economia brasileira.

O impulso da cooperação sul-sul e a formação de novas coalizões e parcerias podem ser considerados os métodos de implantação da PEB de Lula mais emblemáticos, extensamente propagados pelos formuladores da política externa e pelas contrapartes brasileiras. Parceiros não tradicionais da PEB, como Índia, África do Sul, Rússia, China e países do Oriente Médio (Líbano, Egito, Palestina, Israel, Síria, Arábia Saudita, Irã e Iraque) passaram, com o início do governo Lula, a receber atenção especial por parte de setores governamentais, reativando-se relações bilaterais adormecidas e formando-se novas coalizões.

Assistiu-se, nesse sentido, durante os oito anos da administração Lula, ao estabelecimento de novos arranjos político-diplomáticos e coalizões entre países emergentes, como, por exemplo: o mecanismo de coordenação IBAS $^{18}$, o agrupamento BRICS ${ }^{19}$, a Cúpula América do Sul - África (ASA), a Cúpula América do Sul - Países Árabes (ASPA), o Mecanismo BASIC e o G-20 Comercial. Segundo Cervo (2010; 2012), essas coalizões tiveram como meta principal a criação de contrapoder; percebe-se ademais que as novas coalizões serviram para o objetivo geral da política externa brasileira: o de projetar, internacionalmente, o Brasil no contexto internacional e fazê-lo ser visto como global player por seus pares. Para

\footnotetext{
${ }^{18}$ Mecanismo de coordenação político-diplomática formado por Índia, Brasil e África do Sul, fundado em junho de 2003, em Brasília.

${ }^{19}$ Agrupamento formado por Brasil, Rússia, Índia, China e África do Sul, fundado em maio de 2008, cujo objetivo é transformar-se em mecanismo de interação no âmbito dos principais temas da política e da economia global.
} 
além da projeção do país, as novas coalizões serviram ao objetivo brasileiro de promover a reforma da governança global consoante ressalta nota à imprensa divulgada pelo Itamaraty por ocasião da Reunião dos BRICS, em Ecaterimburgo, em maio de 2008:

Os BRICS defendem um cenário internacional baseado no multilateralismo e no direito internacional, com maior participação dos países em desenvolvimento nas instâncias decisórias. Por suas características políticas, econômicas e sociais, os BRICS podem servir como ponte entre o mundo desenvolvido e o mundo em desenvolvimento na promoção do desenvolvimento sustentável e de uma agenda internacional mais equilibrada.

Em paralelo à busca por novas coalizões e formas de cooperação sul-sul, a diplomacia brasileira, durante os anos Lula, empenhou-se em reforçar a agenda de cooperação com parceiros tradicionais, como os Estados Unidos, a União Europeia e o Japão, restaurando canais de comércio tradicionais. A cooperação sul-sul, dessa maneira, não substituiu o relacionamento com os EUA e a União Europeia, mas representou oportunidade de ampliar o comércio e as relações bilaterais brasileiras. Com relação à UE, por exemplo, em Declaração à Imprensa, após a Cúpula BrasilUnião Europeia, em dezembro de 2008, o Presidente Lula destacou:

Queremos um diálogo condizente com uma parceria que já nasceu madura (...). Desde que lançamos a Parceria, na Cúpula de Lisboa, em 2007, confirmaram-se as expectativas quanto ao potencial dessa aliança. Neste ano, nosso intercâmbio comercial cresceu $26 \%$ e superou os US\$ 77 bilhões, ou seja, $22 \%$ do comércio global do Brasil. Os investimentos diretos dos países membros da União Europeia no Brasil, em 2007, somaram US\$ 18 bilhões. Isso equivale a 54\% do que recebemos naquele ano.

A disseminação do conceito de multilateralismo da reciprocidade (CERVO, 2010; 2012) é outro método de execução dos objetivos da política externa brasileira que possui diversas formas de expressão. Segundo Cervo (2010), autor do conceito de multilateralismo da reciprocidade, a partir de 2003, a PEB encontrou mais força para demandar reciprocidade em suas relações internacionais. A diplomacia brasileira, em consequência, passou a adotar diretriz segundo a qual a reciprocidade apenas será garantida em todas as áreas da ordem internacional quando as regras da ordem multilateral beneficiarem todas as nações.

A defesa do multilateralismo como ordem ideal do sistema internacional passou a ser principal bandeira brasileira nas diversas áreas da política internacional 
contemporânea: economia, comércio, finanças, segurança, mudanças climáticas, saúde e direitos humanos. Duas premissas defendidas pela PEB de Lula foram fundamentais para a implantação desse conceito: a existência de regras compartilhadas para o ordenamento internacional e a elaboração conjunta dessas regras, de modo a garantir reciprocidade de efeitos (CERVO, 2010; 2012).

Em aula inaugural do curso de Relações Internacionais da Universidade Federal do Rio de Janeiro (UFRJ), em 13 de abril de 2009, o ministro Celso Amorim destacou a ênfase ao multilateralismo como método de implantação da PEB:

O multilateralismo é a expressão normativa da multipolaridade. O Brasil comunga de visão multilateral das relações internacionais. O multilateralismo interessa ao Brasil, porque nossa ação internacional é pautada pelo pacifismo e por um comprometimento com o direito internacional. A via multilateral, com todas as limitações que tem, contribui para a construção de uma ordem internacional mais justa.

A internacionalização da economia brasileira, por fim, também deve ser levada em consideração como método para se implantar os objetivos da PEB. Segundo Cervo (2012), a partir do governo Lula, a internacionalização de empresas brasileiras foi adotada como uma das principais estratégias da ação externa do país. O objetivo de integrar-se à globalização financeira passou a ser exercido pelo Brasil por meio da busca de acesso a novos mercados e da expansão internacional dos empreendimentos brasileiros. Segundo Cervo (2010; 2012), diferentemente da perspectiva dos anos 1990, um dos objetivos principais do Estado brasileiro a partir do governo Lula passou a ser a formação de empresas nacionais fortes (apoiadas logisticamente e financeiramente pelo Estado) e capazes de competir em escala global. Pode-se perceber que a internacionalização da economia brasileira entrou em ritmo acelerado, a partir de 2005, acompanhando a tendência de outros países emergentes $^{20}$ (CERVO, 2010; 2012).

\footnotetext{
${ }^{20}$ A corrente de comércio do Brasil durante os dois governos Lula cresceu muito em um período em que a corrente de comércio de todos os países, principalmente os em desenvolvimento, também teve crescimento vertiginoso.
} 


\subsection{Conclusão}

O presente capítulo teve por objetivo identificar as principais características, objetivos e metodologias de implantação da Política Externa Brasileira (PEB) durante os dois mandatos do governo de Luiz Inácio Lula da Silva (2003-2010). Por meio de breve análise acerca das principais linhas de continuidade e de ruptura da PEB do governo Lula em relação à PEB do governo FHC, argumenta-se que diversas ações diplomáticas do período Lula deram continuidade a políticas brasileiras iniciadas na década de 1990 - e mesmo a linhas de ação mais antigas, consideradas tradicionais da política exterior brasileira. Por meio de métodos diversos de implantação, durante o governo Lula, os princípios tradicionais da PEB, como autodeterminação dos povos, não intervenção, pacifismo, cordialidade oficial com os vizinhos e respeito ao direito internacional, foram mantidos.

Os ajustes em relação às prioridades e à intensidade das ações de governo sobressaíram no primeiro mandato enquanto a ideia de mudança de programa começou a ter mais força no segundo período do governo Lula, quando a posição de apoio aos regimes internacionais tradicionais durante o governo de FHC cedeu lugar a um papel de promotor da reforma da governança global, fazendo que o Brasil se projetasse internacionalmente como player global. O resgate histórico dos principais eixos da plataforma programática do Partido dos Trabalhadores (PT) no Brasil, ademais, mostrou-se instrumento importante para a compreensão da PEB iniciada, em janeiro de 2003, com a posse do Presidente Lula.

Argumenta-se que a política externa do governo Lula foi caracterizada pelos princípios do nacionalismo, do multilateralismo estratégico, do universalismo, da formação de alianças com parceiros não tradicionais e da liderança regional sulamericana. Posteriormente, verifica-se que os principais objetivos da PEB de Lula, como a presença soberana do Brasil no contexto internacional, a reforma da governança global, a conquista de assento permanente no CSNU, a expansão do comércio internacional e a liberalização de mercados foram implantados por meio de construção e de aplicação de metodologia própria do governo Lula, formulada não apenas pelos tradicionais quadros do Itamaraty, como também por intelectuais vinculados ao Partido dos Trabalhadores, como Marco Aurélio Garcia. 
O novo impulso para a cooperação sul-sul, a busca pelo multilateralismo da reciprocidade, o relacionamento com parceiros não tradicionais e a internacionalização da economia brasileira foram, de 2003 em diante, as principais metodologias de execução da PEB de Lula. Os balanços dessa política externa são recentes em termos de eficiência de resultado, mas observou-se que o objetivo mais geral de expansão da presença soberana do Brasil no mundo, ou seja, de projeção da imagem internacional do Brasil, foi largamente conquistado durante os dois mandatos presidenciais de Lula. Ao longo desse período, por exemplo, foram abertos 67 novos postos diplomáticos, sendo 19 novas embaixadas no continente africano e 6 novos postos no Oriente Médio $^{21}$ (BREDA DOS SANTOS, 2014).

O próximo capítulo tem por objetivo examinar, por meio dos diversos papéis projetados pelo Brasil, de que forma a busca por aproximação com parceiros não tradicionais durante a PEB de Lula se deu em relação aos países do Oriente Médio. Argumenta-se que a reaproximação e a intensificação das relações do Brasil com a região do Oriente Médio foram parte da estratégia metodológica do governo Lula de cooperação com parceiros não tradicionais (cooperação sul-sul), para atingir o objetivo da PEB de Lula de reforma da governança global e, mais especificamente, de conquista do assento permanente no CSNU. De forma complementar, pretende-se analisar como - em relação à região do Oriente Médio - a característica da PEB de formação de novos arranjos político-diplomáticos alternativos ao status quo vigente no sistema internacional foi arquitetada ao longo dos dois períodos do governo Lula.

\footnotetext{
${ }^{21}$ No período entre 2003-2010, três novas embaixadas foram abertas no Oriente Médio - Mascate (Omã), Nicósia (Chipre) e Doha (Catar) - além de três novos consulados - Istambul (Turquia), Ramalá (Palestina) e Beirute (Líbano) (BREDA DOS SANTOS, 2014).
} 


\section{CAPÍTULO 2: Os papéis secundários projetados pela Política Externa Brasileira para o Oriente Médio durante os governos Lula (2003-2010)}

O presente capítulo tem por objetivo apresentar e discutir os quatro papéis secundários concebidos pelos formuladores de Política Externa Brasileira para a região do Oriente Médio durante os dois mandatos do Presidente Lula (2003-2010). Utilizando-se da Role Theory, defende-se a ideia de que a PEB concebeu o papel do Brasil para aquela região como: ponte entre os povos, países e regiões; defensor da paz e dos direitos humanos; agente promotor de assistência humanitária internacional; criador de novos arranjos políticos, diplomáticos e econômicos alternativos ao status $q u o$; mediador de conflitos ou construtor de consensos, considerado o principal.

Esses papéis foram implantados por meio de três principais estratégias metodológicas: intensificação de visitas de alto nível, aumento do fluxo de trocas comerciais entre as duas regiões, além de criação de dotação orçamentária especial para a promoção de assistência humanitária internacional. Defende-se neste capítulo que houve hierarquização desses papéis. O de ponte foi classificado como pré-papel, ou seja, como porta de entrada para a consecução dos três outros secundários (defensor da paz e dos direitos humanos, promotor de assistência humanitária internacional e criador de novos arranjos políticos, diplomáticos e econômicos) e do principal, o de mediador de conflitos. Nesse sentido, argumenta-se que todos os papéis estrategicamente formulados tiveram como objetivo principal o alcance de uma das fundamentais metas da diplomacia brasileira: a reforma da governança global e, em particular, a reforma da principal instância multilateral de segurança internacional, o Conselho de Segurança das Nações Unidas.

\subsection{Role Theory: breve apresentação}

Os estudos da Role Theory, aplicados às Relações Internacionais e, em particular, à análise de política externa, surgiram na década de 1970, com a publicação de artigo na revista International Studies Quarterly, intitulado National Role Conceptions in the Study of Foreign Policy, do professor canadense Kalevi 
Holsti. Seus fundamentos encontram-se especialmente naquelas disciplinas que pesquisam o conceito de identidade, como a Sociologia, a Psicologia e a Antropologia. A aplicação da Role Theory às Relações Internacionais durante a Guerra Fria não foi por acaso: à época, os pesquisadores tinham como meta averiguar padrões regulares de comportamento entre os Estados, durante a estrutura bipolar mundial. As pesquisas no marco do Role Theory surgiram, consequentemente, de forma a entender quais padrões de comportamento caracterizavam países denominados não alinhados, aliados e satélites (HOLSTI, 1970; HARNISCH, 2012).

O conceito de papel possui a vantagem de fazer interface com os três níveis de análise em política externa: o indivíduo, a sociedade e o sistema (LE PRESTE, 1997). De acordo com Holsti (1970:238), o papel diz respeito à posição ocupada por um indivíduo, uma sociedade ou um Estado no sistema internacional e ao conjunto de normas e de expectativas de comportamento a ser aplicadas a todos que ocupam a mesma posição. O conceito postula que os atores conhecem as normas que constituem seu papel e, conscientes, tendem a adaptar seu comportamento aos papéis que ocupam (HOLSTI, 1970), cujas fontes podem ser encontradas tanto em variáveis internas como em fatores externos. Sua classificação é binária: há os impostos pela sociedade (ascribed) e os escolhidos pelos atores (achieved) (LE PRESTE, 1997).

De acordo com Harnisch (2012), o conceito de role pode ser definido como posições sociais constituídas pelas expectativas do ego e do alter. Aggestam (1998), em paralelo, ao focalizar o nível de análise estatal, acrescenta que o conceito de papel pode ser considerado como ferramenta metodológica por meio da qual é possível apreender a relação entre identidade e política externa e prevê relação analítica entre a construção da identidade de um Estado e o seu comportamento em política externa.

A Role Theory, apresentada por Kalevi Holsti em 1970, enfatiza a interação de três conceitos essenciais: a concepção do papel nacional, a percepção do papel nacional e o desempenho desse papel. Dessa forma, a national role performance, ou seja, a atuação em política externa de um Estado é diretamente influenciada por dois conceitos basilares: a concepção dos formuladores de política externa acerca do papel de seu país no sistema internacional e a percepção e a legitimação de outros atores, do alter, acerca do papel autoconcebido pelo país. A figura 4, abaixo, esquematiza a Role Theory e as fontes do comportamento humano e estatal ${ }^{22}$.

\footnotetext{
${ }^{22}$ Elaboração com base em Holsti (1970).
} 
Figura 4: A Role Theory e as fontes do comportamento humano e estatal ${ }^{23}$

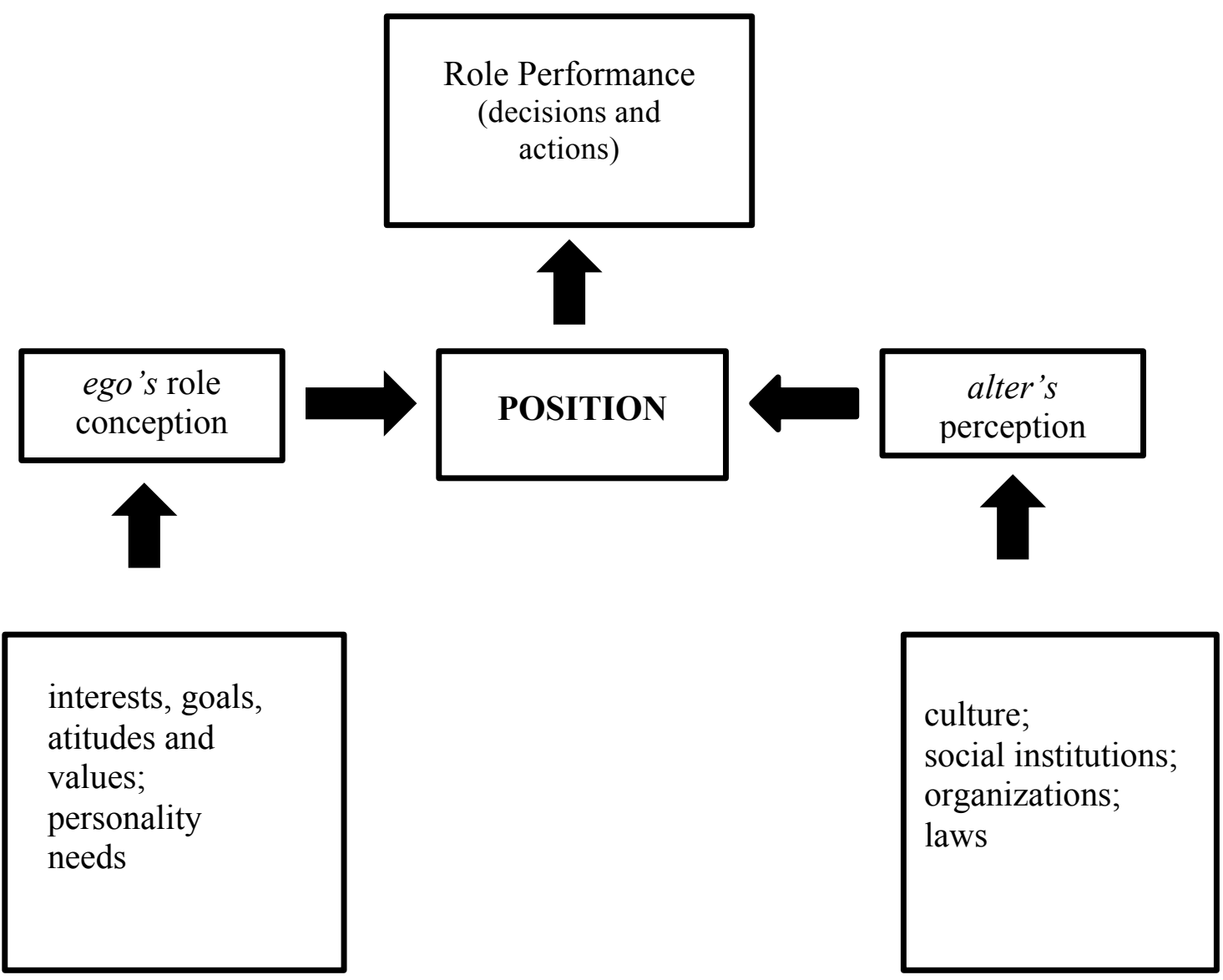

A concepção do papel nacional, segundo Holsti (1970), inclui as definições dos policymakers acerca das decisões gerais, das regras e das ações adequadas aos seus Estados e às funções que seu governo deve possuir em um sistema internacional. É a sua imagem de orientações apropriadas ou funções de seu Estado no ambiente internacional. De forma análoga, Aggestam (1998) explica que a concepção do papel nacional é a definição dos policymakers com respeito às decisões, aos comprometimentos, às regras e às ações que se adaptam a cada Estado. Harnisch (2012) interpreta Holsti (1970), ao elucidar que a concepção do papel nacional diz respeito às percepções de um ator internacional acerca de sua posição vis-à-vis aos outros atores (a parte ego dentro de um role).

\footnotetext{
${ }^{23}$ International Studies Quarterly.
} 
Grande parte das contribuições da literatura da Role Theory em política externa prioriza a decodificação de discursos de indivíduos-chave para a construção e a identificação de concepções do papel nacional. Observa-se, por exemplo, quando um formulador de política externa fala acerca de comprometimentos, de deveres, de funções e de responsabilidades, o que indica expectativa de comportamento do Estado em política externa. Segundo Le Preste (1997), aquilo que homens de Estado ${ }^{24}$ e diplomatas dizem é, normalmente, tão vital quanto aquilo o que fazem. Dessa forma, sendo a fala uma forma incisiva de ação, as concepção dos papéis nacionais serviriam para moldá-las (THIES, 2009; LE PRESTE, 1997; AGGESTAM, 1998).

De acordo com Holsti (1970), quanto mais um Estado está envolvido no ambiente internacional, melhor estruturados e bem concebidos os seus papéis nacionais estarão. Ou seja, quanto mais ativo ou envolvido um Estado está nos assuntos internacionais ou regionais, mais concepções do seu papel nacional serão percebidas e projetadas por seus líderes. Na literatura original da Role Theory, formulada por Kalevi Holsti, o autor identificou, inicialmente, dezessete principais papéis nacionais ${ }^{25}$. Sabe-se, atualmente, que os formuladores de política externa tendem a conceber, paralelamente, diferentes papéis para seus Estados, fazendo que existam dezenas de outras concepções de papéis nacionais não mutuamente excludentes, mas sobrepostas (HOLSTI, 1970; AGGESTAM, 1998).

Segundo argumento defendido por Holsti (1970), apesar de não haver ligação perfeita entre as concepções do papel nacional e as decisões de política externa, quantidade expressiva de atitudes de política externa tendem a ser compatíveis com as concepções do papel nacional formuladas por seus policymakers. Holsti (1970) vai além, em sua análise, ao afirmar que o sistema internacional pode ser concebido, de forma analítica, não apenas como padrões de interação, mas também como uma distribuição particular de várias concepções de papéis nacionais.

Apesar de os estudos em política externa tenderem a enfatizar a concepção do papel nacional, ou seja, a dos formuladores de política externa acerca do papel de seu país no mundo como determinantes do comportamento e dos interesses nacionais,

\footnotetext{
${ }^{24}$ Segundo Le Preste (1997), os principais atores e formuladores do National Role Conception são os chefes de Estado, os chefes de Governo, os ministros das Relações Exteriores e seus assessores.

${ }^{25}$ Kalevi Holsti (1970:260-272), em seu artigo National Role Conceptions in the Study of Foreign Policy, identificou dezessete principais national role conceptions, quais sejam: bastião da revolução (libertador), líder regional, protetor regional, independente, apoio à libertação, agente anti-imperialista, defensor da fé, mediador, colaborador do subsistema regional, desenvolvimentista, ponte, aliado fiel, independente, exemplo, desenvolvimentista interno, isolacionista e protetor.
} 
outro conceito essencial, porém normalmente negligenciado é o de percepção do papel nacional: a audiência (HOLSTI, 1970). Esse conceito emana de acordo com várias circunstâncias do ambiente externo e diz respeito a expectativas que culturas, sociedades, instituições ou grupos conferem a determinadas posições ocupadas pelos Estados (THIES, 2009; HOLSTI, 1970).

O desempenho do papel nacional é um conceito que diz respeito à ação e ao comportamento geral de política externa dos governos; são padrões de atitudes, ações, decisões, respostas, funções e compromissos com outros Estados que os governos implantam. Esse conceito pode ser explicado, primeiramente, em referência às próprias concepções dos policymakers acerca do papel de sua nação na região ou no sistema internacional $\mathrm{e}$, de forma secundária, conforme as expectativas $\mathrm{e}$ as percepções dos outros atores relevantes no sistema internacional (HOLSTI, 1970; AGGESTAM 1998).

As categorias sociais de papel e identidade estão estreitamente entrelaçadas no trabalho da maioria dos pesquisadores que utilizam o Role Theory como instrumental metodológico. Como o conceito de identidade é relacional, ou seja, depende da existência do outro - o alter - para conformar-se e consolidar-se, a noção de audiência e de coletividade é necessária para a autoconcepção do Estado acerca de seu papel no sistema internacional, sua condição de Estado e sua soberania. Dessa forma, a análise de discursos de política externa, uma das principais ferramentas metodológicas empregadas por pesquisadores do Role Theory, tende a revelar sentimentos subjetivos de pertencimento do grupo no poder do Estado em questão, relacionados a costumes, instituições, territórios, mitos e questões culturais. Mudanças na forma de conceber o papel da Nação no sistema internacional, por exemplo, são propensas a ter grandes implicações nas ações de política externa e na ideia de identidade nacional (AGGESTAM, 1998; HARNISCH, 2012).

As mudanças em política externa implicam redefinição do papel do Estado no sistema internacional. Dessa forma, modificações na maneira como os principais formuladores de política externa concebem o Estado a que pertencem e como dirigem a sua concepção de papel nacional ou, por outro lado, mudanças na forma como os outros Estados ou atores importantes do sistema internacional (significant others ${ }^{26}$ )

\footnotetext{
${ }^{26}$ De acordo com Harnisch (2012), o conceito de significant others é central no estudo do interacionismo, e, no caso da Role Theory, a maior parte dos roles não pode ser concebida sem a
} 
concebem o papel do Estado são determinantes tanto para o engajamento do Estado em novo papel quanto, em sentido amplo, para a redefinição de nova identidade para o Estado (LE PRESTE, 1997; HARNISCH, 2012).

As denominadas mudanças nos papéis ocorrem quando os Estados enfrentam conflitos entre papéis diferentes ou no mesmo papel, ou seja, quando os agentes estatais redefinem sua concepção de papel nacional ou quando a audiência externa e os significant others redefinem as expectativas e a forma como consideram o outro Estado (national role prescriptions). As fontes de mudanças nos papéis exercidos pelos Estados, consequentemente, podem ser internas, externas, bottom-up, top-down, inside-out e outside-in (LE PRESTE, 1997; HARNISCH, 2012).

De acordo com Le Preste (1997), o conflito entre Estados no sistema internacional contemporâneo ocorre por três principais causas. A primeira é quando há discrepância entre a concepção do papel nacional do próprio Estado e a expectativa do papel nacional da audiência e dos significant others. Esse conflito de percepções pode impedir a cooperação entre os países ou ocasionar rompimentos e grandes malentendidos. A segunda fonte de conflito são elaborações de concepção de papéis nacionais contraditórias. Isso ocorre, segundo Le Preste (1997), quando os formuladores de política externa possuem noções discrepantes acerca do papel do Estado que representam no sistema internacional. A terceira causa está na inércia de alguns países que insistem na retenção de papéis tradicionais em um contexto internacional de grandes mudanças (LE PRESTE, 1997; HARNISCH, 2012).

A Role Theory tem grande valor para a análise de política externa, principalmente, em razão de sua habilidade em cruzar diferentes níveis de análise e pelo fato de que os papéis desempenhados, concebidos, legitimados ou deslegitimados por um Estado ajudam a definir os interesses nacionais (HOLSTI, 1970; LE PRESTE, 1997; THIES, 2009). Para Le Preste (1997), por exemplo, definir um papel e tê-lo aceito por outros atores do sistema internacional continua sendo o objetivo principal dos Estados. O papel, dessa forma, refletiria um pedido de reconhecimento aos Estados que compõem o sistema internacional e, antes de tudo, uma concepção própria de identidade nacional. 


\subsection{Ponte: o pré-papel e a "porta de entrada" para papéis posteriores}

De acordo com Holsti (1970: 266-267), a concepção do papel nacional de ponte, normalmente, aparece de forma vaga, e as políticas dela derivadas não são aparentes. Desse modo, enquanto o papel de mediador implica várias formas de interposição diplomática em áreas ou temas de conflito, o conceito de ponte é efêmero. Para Holsti (1970: 266-267), esse papel tem a função de comunicador, ou seja, o país atua, internacionalmente, como tradutor ou conversor de mensagens e informações entre povos de diferentes culturas. $\mathrm{O}$ autor cita o exemplo da posição geográfica estratégica da ilha de Chipre, para elucidar que as fontes do papel de ponte se encontram, principalmente, na localização geográfica e na composição multiétnica do Estado que exerce essa função (HOLSTI, 1970: 297).

O papel de ponte entre povos, países e regiões foi reiteradamente utilizado pelos formuladores e pelos executores da PEB durante o governo Lula como um dos principais papéis a ser desempenhados pelo Brasil em relação à região do Oriente Médio. Empregado de forma profusa e pouco definida conceitualmente, o papel de ponte esteve presente a, praticamente, todos os discursos, palestras, entrevistas, notas à imprensa e artigos formulados pelo governo brasileiro em relação aos países árabes, ao Irã e à Israel. Nesse universo de documentos, 53 deles fazem referência - explícita ou implícita - ao papel do Brasil como ponte entre as duas regiões e entre os dois povos.

Por diversas vezes, o Presidente Lula e o chanceler Celso Amorim declararam, em seus discursos e artigos para a mídia nacional e internacional, o papel do Brasil como ponte em relação aos países do Oriente Médio: "ponte de integração entre os povos" (MRE, 2005a); "ponte de amizade e de cooperação (...) que liga povos e culturas" (MRE, 2003b); "ponte de sólida cooperação entre a América do Sul e o mundo árabe" (MRE, 2005a); "ponte entre os dois continentes" (MRE, 2010a); “construímos pontes e políticas entre regiões que vivem distantes umas das outras" (MRE, 2010b).

As duas edições da Cúpula América do Sul-Países Árabes (ASPA), ocorridas em Brasília e em Doha, respectivamente, foram um dos principais eventos nos quais o Estado brasileiro se colocou como ponte entre os povos árabes e o mundo ocidental (a América do Sul em especial). A Cúpula ASPA, nas palavras do Presidente Lula, durante a sessão de abertura, em maio de 2005, em Brasília, foi uma "oportunidade 
histórica de lançar os fundamentos de uma ponte de sólida cooperação entre a América do Sul e o mundo árabe" (MRE, 2005a). Em termos práticos, o Presidente Lula destacou, em seminário empresarial Brasil-Catar, no último ano de seu mandato, em maio de 2010, o quanto o comércio entre os dois continentes aumentou exponencialmente: “Com a Cúpula ASPA, estamos consolidando uma ponte ${ }^{27}$ entre dois continentes. Nosso comércio alcança US\$ 20 bilhões - aumento de $150 \%$ desde a I Cúpula ASPA, em Brasília, em maio de 2005” (MRE, 2010a).

Argumenta-se que a concepção do papel nacional de ponte foi empregada pelos formuladores e pelos executores da PEB como estratégia preliminar para alcançar empatia com seus variados interlocutores. A PEB, dessa forma, valeu-se, reiteradamente, de recursos argumentativos, como o histórico da identidade étnica comum e a imigração árabe e judaica para o Brasil nos séculos XIX e XX, a fim de conseguir, primeiramente, atingir a legitimidade de seus interlocutores no plano internacional e, posteriormente, projetar novos papéis do Brasil para o Oriente Médio, tais como: mediador de conflitos, promotor de assistência humanitária internacional, criador de contrapoder, defensor da paz e dos direitos humanos. Por outro lado e de forma destacada, a utilização do papel de ponte serviu para a projeção de um dos principais e mais tradicionais objetivos da PEB: a reforma da governança global e, em especial, do Conselho de Segurança das Nações Unidas. A figura 5 ilustra, sinteticamente, os papéis formulados pela PEB para a região do Oriente Médio durante o Governo Lula ${ }^{28}$.

\footnotetext{
${ }^{27}$ Grifo nosso.

${ }^{28}$ Elaboração da autora.
} 
Figura 5: Papéis formulados pela PEB para a região do Oriente Médio durante o Governo Lula (2003-2010)

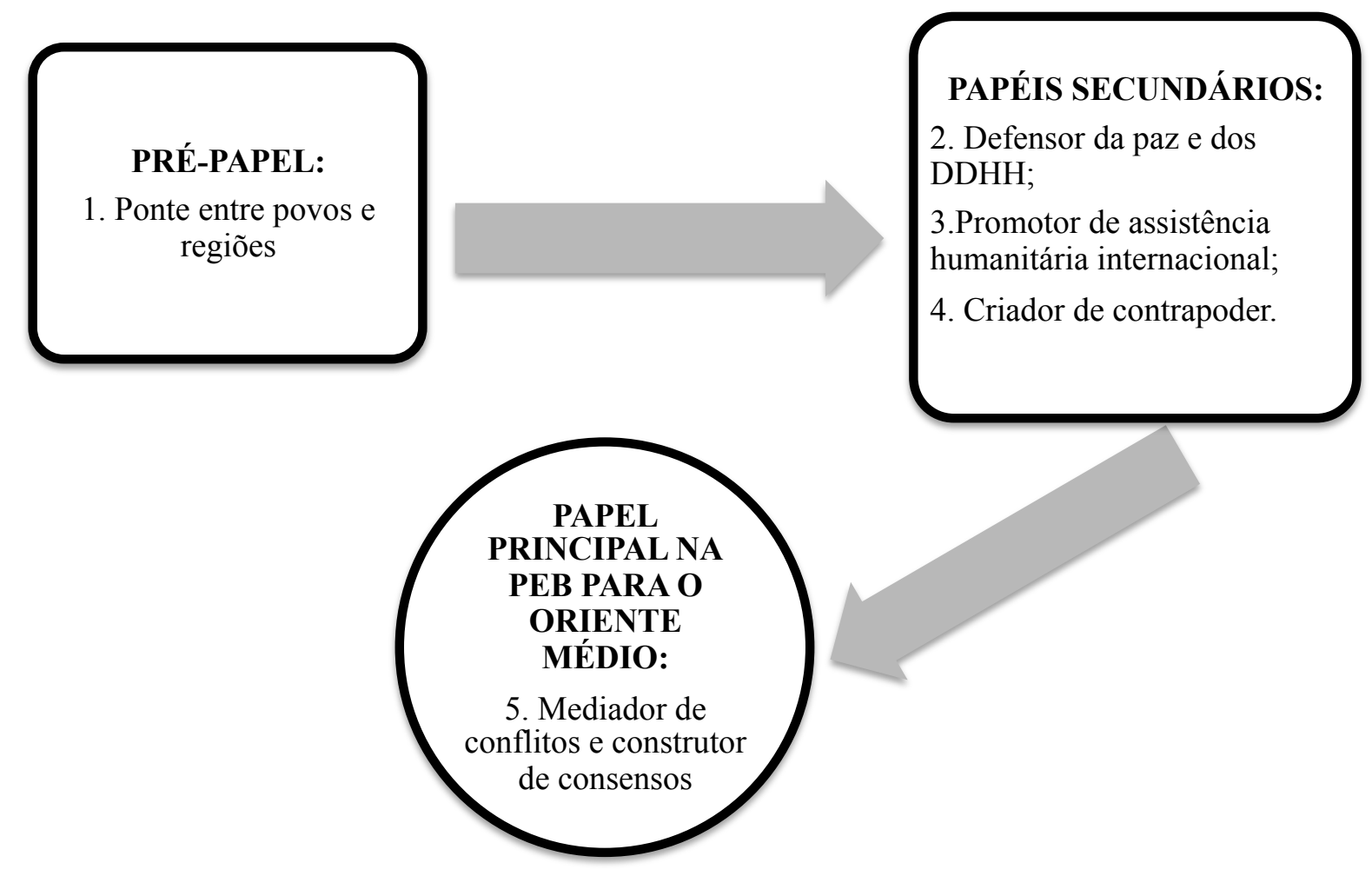

Objetivo dos papéis:

Influenciar a reforma da governança global

O papel autoconcebido pelo Brasil como ponte entre os povos do Ocidente e do Oriente e entre as duas regiões geográficas foi sustentado nos discursos brasileiros em relação à região do Oriente Médio, por meio de quatro argumentos principais: influência árabe sobre a Península Ibérica; histórico da imigração árabe e judaica para o Brasil; expressivo número de descendentes de árabes e judeus na população brasileira; intensa contribuição valorativa de herança árabe para a formação da identidade brasileira. Percebe-se, no entanto, preponderância de referências à contribuição árabe na formação da sociedade brasileira, em relação à influência judaica, principalmente no que diz respeito à contribuição cultural e à importância da 
comunidade de imigrantes e de seus descendentes residentes no Brasil (MRE, 2003a; 2003b; 2004a; 2005a; 2006b; 2007a; 2008a; 2008b; 2009a; 2009b; 2010a).

A herança colonial portuguesa no Brasil, que trouxe consigo a indissociável influência árabe e a islâmica sobre a Península Ibérica, foi levantada em discursos da política externa brasileira, acerca dos vínculos tradicionais entre o Brasil e o mundo árabe. De forma bem mais intensa que a herança ibérica, o histórico da imigração árabe e judaica para o Brasil e o papel desses imigrantes para a formação da identidade nacional foram repetidamente lembrados logo nos primeiros momentos dos discursos de acolhida, durante as visitas de autoridades da região ao Brasil e de chegada de representantes oficiais brasileiros aos países da região do Oriente Médio (MRE 2003a; 2003b; 2005a; 2009a; 2010a).

$\mathrm{O}$ argumento numérico e estatístico também foi utilizado diversas vezes pelos formuladores da PEB para demonstrar a expressiva presença árabe no Brasil e para legitimar o papel brasileiro de ponte entre as duas regiões e povos. A influência da imigração judaica no Brasil, por outro lado, foi destacada por meio de adjetivos, como “expressiva", "importante”, mas não de forma numérica como a presença árabe. O chanceler Celso Amorim e o Presidente Lula, dessa forma, valeram-se de números, como, por exemplo, os 10 milhões de brasileiros descendentes de árabes, os 7 milhões de descendentes de libaneses no Brasil (maior comunidade de libaneses e de seus descendentes no mundo), os 2,5 milhões de descendentes de sírios, e o fato de $20 \%$ dos membros do Congresso Nacional no Brasil fazerem parte da Associação dos Descendentes de Árabes, para embasar a suposta legitimidade do Brasil de exercer o papel de ponte entre as duas regiões e entre os povos árabes, judeus e ocidentais (MRE, 2003b; 2004a; 2005a; 2006b; 2007a; 2008a; 2008b; 2009b; 2010a).

De maneira paralela, os formuladores de política externa brasileira ressaltaram a intensa contribuição valorativa de herança árabe para a identidade brasileira. Como enunciado por diversas vezes nos discursos elaborados pela diplomacia brasileira e pela Presidência da República, a identidade do povo brasileiro recebeu forte herança de aspectos advindos dos imigrantes árabes que desembarcaram no Brasil, em fins do século XIX. Características, como cordialidade, respeito, grande capacidade adaptativa, força de trabalho, vontade de vencer, determinação e luta por sociedade justa, foram destacadas pelos formuladores de política externa brasileira. Nas fontes primárias pesquisadas, nada foi dito ou escrito em relação à contribuição valorativa judaica para a sociedade brasileira. Os discursos da PEB do governo Lula, nesse 
sentido, tiveram como objetivo demonstrar a decisiva contribuição árabe para a formação da identidade social e da cultura brasileira e para o desenvolvimento econômico do país (MRE, 2003b; 2009b; 2010a). A tabela 3, a seguir, identifica as justificativas da PEB para legitimar-se como ponte entre povos e regiões ${ }^{29}$.

Tabela 3: Justificativas da PEB para legitimar-se como ponte entre povos e regiões

\begin{tabular}{|c|c|}
\hline $\begin{array}{l}\text { Argumentos para } \\
\text { justificar o papel da } \\
\text { PEB como PONTE }\end{array}$ & Extratos de discursos \\
\hline $\begin{array}{l}\text { Influência árabe sobre a } \\
\text { Península Ibérica; } \\
\text { colonização portuguesa }\end{array}$ & $\begin{array}{l}\text { "O rico patrimônio da civilização árabe-islâmica esteve } \\
\text { presente nos primórdios do Brasil, por sua forte influência } \\
\text { sobre a Península Ibérica, de onde vieram os } \\
\text { colonizadores portugueses } 30 \text { " (MRE, 2003b). } \\
\text { "Ligam-nos aos países árabes as raizes ibéricas do Brasil, } \\
\text { fortemente influenciadas pela presença islâmica" } 31 \text { " (MRE, } \\
\text { 2003b). }\end{array}$ \\
\hline $\begin{array}{l}\text { Histórico de imigração } \\
\text { árabe e judaica no } \\
\text { Brasil }\end{array}$ & $\begin{array}{l}\text { "Há muito tempo, milhares de irmãos libaneses } \\
\text { escolheram o Brasil como sua segunda pátria. Alguns até } \\
\text { já transformaram o Brasil na primeira pátria 32," (LULA, } \\
\text { 2003). } \\
\text { "O Líbano é uma terra cara ao Brasil pela importância } \\
\text { da comunidade de origem libanesa em nosso país e pela } \\
\text { notável contribuição que o imigrante libanês deu ao nosso } \\
\text { desenvolvimento como Nação } 33 \text { " (MRE, 2003a). } \\
\text { "Milhares de imigrantes árabes desembarcaram em terras } \\
\text { brasileiras, buscando nova vida } 34 \text { " (MRE, 2003b). } \\
\text { "Liga-nos aos países árabes (...) a importante imigração } \\
\text { proveniente do Libano e da Síria } 35 \text { ", (MRE, 2003b). }\end{array}$ \\
\hline
\end{tabular}

${ }^{29}$ Elaboração com base em MRE, 2003a; 2003b; 2004a; 2005a; 2006b; 2007a; 2008a; 2008b; 2009a; 2009b; 2010 a; AMORIM, 2011.

${ }^{30}$ Discurso do Presidente Lula por ocasião da visita à sede da Liga dos Estados Árabes. Cairo, 9 de dezembro de 2003.

${ }^{31}$ Nota à imprensa. Visita do Presidente Luiz Inácio Lula da Silva a Países Árabes. Brasília, 2 de dezembro de 2003.

${ }^{32}$ Discurso do Presidente Lula por ocasião do encerramento do seminário empresarial Brasil-Líbano, em Beirute, 5 de dezembro de 2003.

${ }^{33}$ Declaração do Presidente Luiz Inácio Lula da Silva à imprensa por ocasião da visita de trabalho do Presidente do Conselho de Ministros do Líbano - Rafik Hariri. Brasília, 10 de junho de 2003.

${ }^{34}$ Discurso do Presidente Lula por ocasião da visita à sede da Liga dos Estados Árabes. Cairo, 9 de dezembro de 2003.

${ }^{35}$ Nota à imprensa. Visita do Presidente Luiz Inácio Lula da Silva a Países Árabes. Brasília, 2 de dezembro de 2003 . 


\begin{tabular}{|c|}
\hline 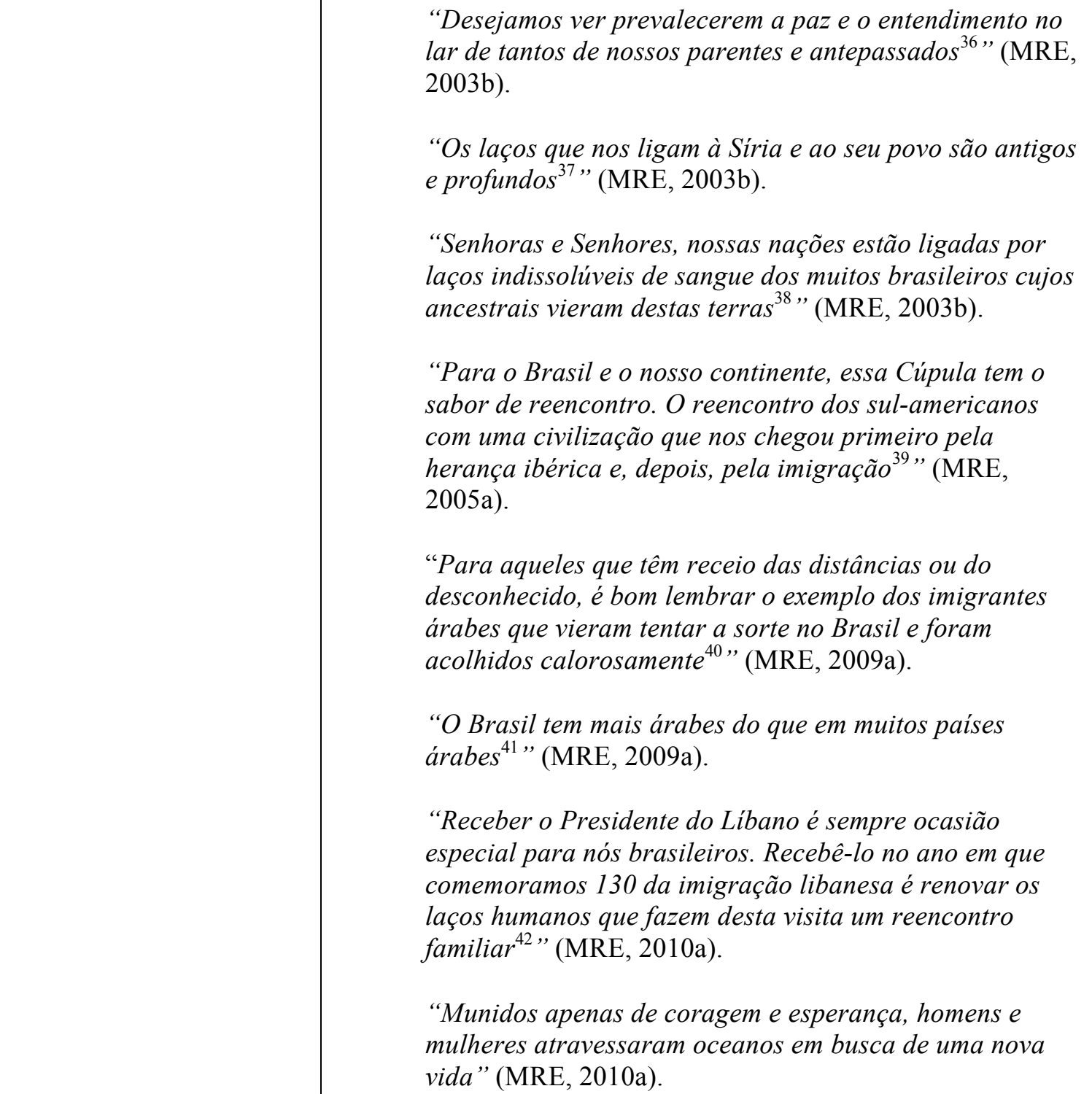 \\
\hline
\end{tabular}

${ }^{36}$ Discurso do Presidente Lula durante jantar oferecido pelo Presidente da Síria, Bashar Al-Assad. Damasco, 3 de dezembro de 2003.

${ }^{37}$ Discurso do Presidente Lula por ocasião do encerramento do seminário sobre Negócios e investimentos. Damasco, 3 de dezembro de 2003.

${ }^{38}$ Discurso do Presidente Lula no plenário da Assembleia Nacional Libanesa, em Beirute, em 5 de dezembro de 2003.

${ }^{39}$ Discurso do Presidente Lula na sessão de abertura da Cúpula América do Sul - Países Árabes (ASPA) - em Brasília, 10 de maio de 2005.

${ }^{40}$ Discurso do Presidente Lula por ocasião de almoço na Câmara de Comércio na Arábia Saudita. Riade, 17 de maio de 2009.

${ }^{41}$ Visita do Presidente Lula à Arábia Saudita. Discurso do Presidente Lula por ocasião do almoço na Câmara de Comércio na Arábia Saudita. Riad, 17 de maio de 2009.

${ }^{42}$ Discurso do Presidente Lula durante almoço oferecido ao Presidente do Líbano - Michel Sleiman. Brasília, 22 de abril de 2010. 


\section{Expressivo número de descendentes árabes $\mathrm{e}$ judeus}

"Os mais de 10 milhões de brasileiros descendentes desses imigrantes, que hoje vivem em meu pais, mantiveram elos com sua civilização materna ${ }^{43}$ ", (MRE, 2003b).

"Nossas relações têm uma dimensão humana única, que se expressa na comunidade de mais de 2 milhões de descendentes de sirios que vivem no Brasil ${ }^{44}$ ", (MRE, 2003b).

"Possivelmente, os empresários sírios terão de reaprender com os quase 3 milhões de sírios que, um dia, não mediram esforços para ir ao Brasil, não viram oceanos e nem viram deserto e estão vivendo, no Brasil, em paz e harmonia, ajudando o nosso país e a Síria crescerem $^{45}$ ", (MRE, 2003b).

"São, hoje, entre 6 e 7 milhões de homens e mulheres descendentes dos imigrantes libaneses que começaram a chegar ao Brasil, na segunda metade do século XIX ${ }^{46,}$ (MRE, 2003b).

"Temos fortes elos anos unir. Basta recordar o contingente de dezenas de milhares de brasileiros de origem árabe que atuam nas mais diversas cadeias

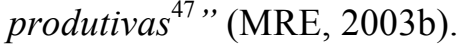

"Mais tarde, milhares de imigrantes árabes desembarcaram em terras brasileiras, buscando nova vida. Os mais de 10 milhões de brasileiros descendentes desses imigrantes que, hoje, vivem em meu pais mantiveram elos com sua civilização materna" (MRE, 2003b)

"A Síria é um país com o qual o Brasil mantém, historicamente, estreitos laços em virtude da numerosa e importante comunidade de origem siria no Brasil, com mais de 2 milhões de pessoas" (MRE, 2003b).

\footnotetext{
${ }^{43}$ Discurso do Presidente Lula por ocasião da visita à sede da Liga dos Estados Árabes. Cairo, 9 de dezembro de 2003

${ }^{44}$ Discurso do Presidente Lula durante jantar oferecido pelo Presidente da Síria, Bashar Al-Assad. Damasco, 3 de dezembro de 2003.

${ }^{45}$ Discurso do Presidente Lula por ocasião do encerramento do seminário sobre Negócios e investimentos. Damasco, 3 de dezembro de 2003.

${ }^{46}$ Discurso do Presidente Lula no plenário da Assembleia Nacional Libanesa. Beirute, 5 de dezembro de 2003.

${ }^{47}$ Discurso do Presidente Lula no Seminário Empresarial Brasil-Egito, no Cairo, em 8 de dezembro de 2003.
} 


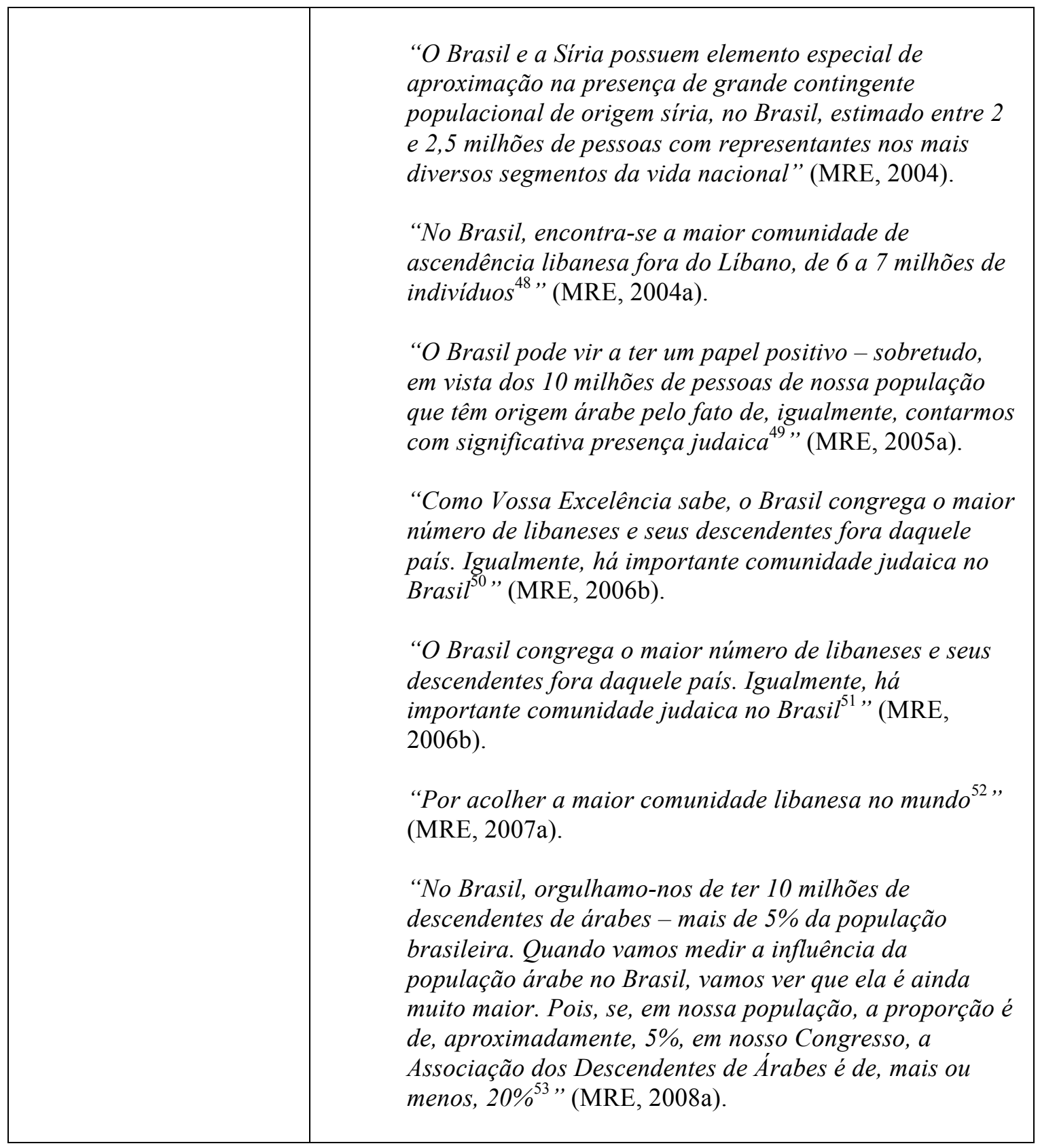

\footnotetext{
${ }^{48}$ Nota à imprensa. Visita do Presidente da República Libanesa, Émile Lahoud. Brasília, 20 de fevereiro de 2004.

${ }^{49}$ Entrevista do ministro das Relações Exteriores, Celso Amorim, publicada no jornal Al Rayah, do Catar, e reproduzida pelo jornal árabe Al Ahram em suas edições do Cairo, de Beirute, de Damasco e de Londres, em 23 de fevereiro de 2005.

${ }^{50}$ Carta do Presidente Lula ao secretário-geral da ONU, Kofi Annan, sobre a situação no Líbano. Brasília, 3 de agosto de 2006.

${ }^{51}$ Carta do Presidente da República Federativa do Brasil, Luiz Inácio Lula da Silva, ao secretário-geral da ONU sobre a situação no Líbano. Brasília, 3 de agosto de 2006.

${ }^{52}$ Palestra do ministro Celso Amorim na Conferência Internacional de Apoio ao Líbano. Paris, 25 de janeiro de 2007.

${ }_{53}$ Discurso do ministro das Relações Exteriores, Celso Amorim, por ocasião da Reunião de Ministros das Relações Exteriores da Cúpula América do Sul - Países Árabes. Buenos Aires, 20 de fevereiro de 2008 .
} 


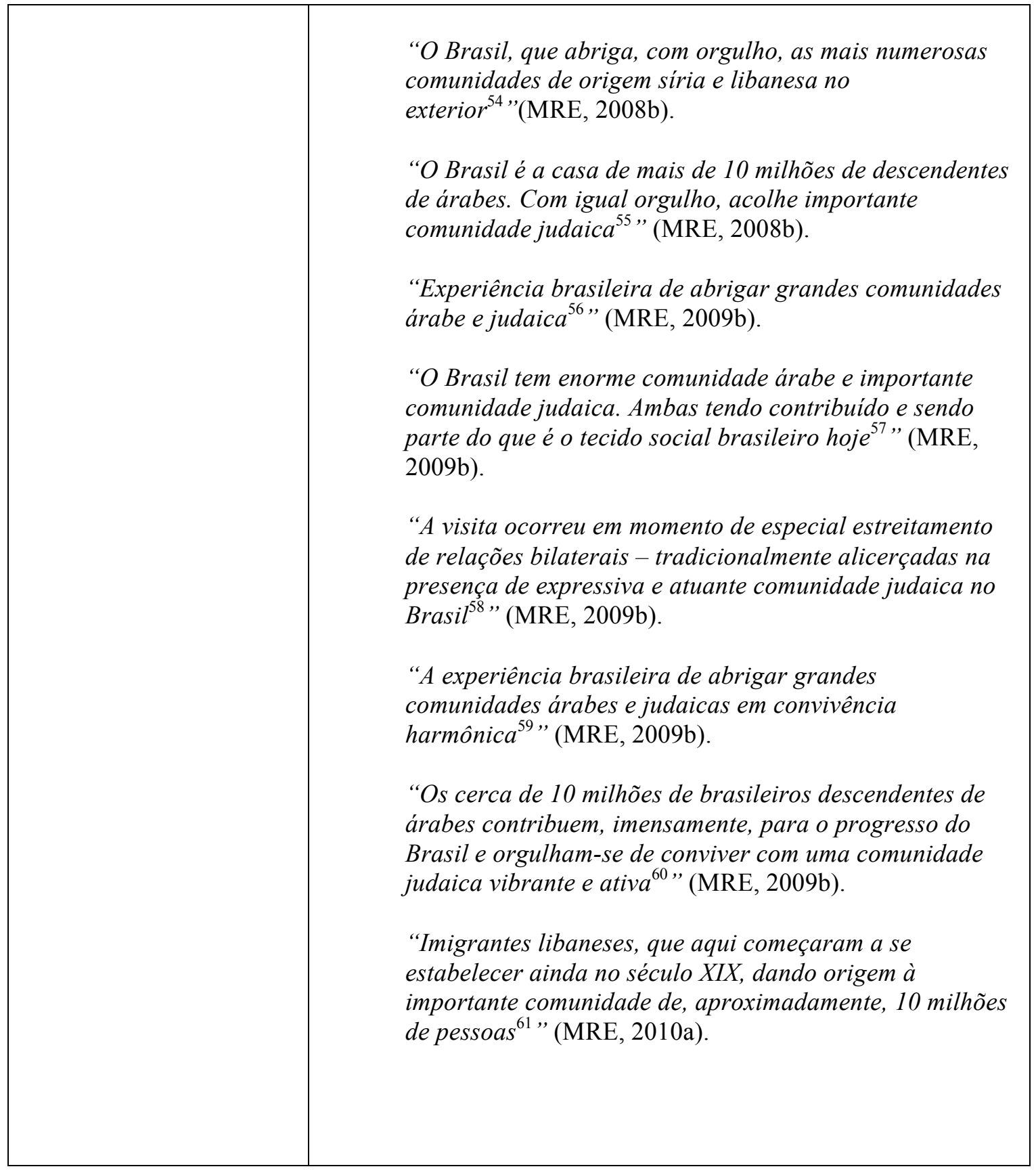

${ }^{54}$ Nota à imprensa. Estabelecimento de relações diplomáticas plenas entre a Síria e o Líbano. Brasília, 25 de agosto de 2008.

${ }^{55}$ Discurso do Presidente Luiz Inácio Lula da Silva por ocasião do almoço em homenagem à Sua Majestade o Rei Abdullah II, da Jordânia. Brasília, 23 de outubro de 2008.

${ }^{56}$ Declaração do Presidente Lula à imprensa após a assinatura de atos, por ocasião da visita do Presidente do Irã, Mahmoud Ahmadinejad. Brasília, 23 de novembro de 2009.

${ }^{57}$ Apresentação do ministro das Relações Exteriores, Celso Amorim, no Seminário Internacional de mídia sobre a paz no Oriente Médio, organizado pela ONU. Rio de Janeiro, 27 de julho de 2009.

${ }^{58}$ Nota à imprensa. Visita do Presidente de Israel, Shimon Peres, ao Brasil, de 10 a 15 de novembro de 2009.

${ }^{59}$ Declaração do Presidente Luiz Inácio Lula da Silva à imprensa após a assinatura de atos, por ocasião da visita do Presidente do Irã, Mahmoud Ahmadinejad. Brasília, 23 de novembro de 2009.

${ }^{60}$ Declaração do Presidente Luiz Inácio Lula da Silva à imprensa por ocasião da visita do Presidente da Autoridade Nacional Palestina, Mahmoud Abbas, a Salvador-BA, em 20 de novembro de 2009.

${ }^{61}$ Nota à imprensa. Visita do Presidente da República Libanesa, General Michel Sleiman, ao Brasil. Brasília, São Paulo e Rio de Janeiro, de 21 a 26 de abril de 2010. 


\begin{tabular}{|c|c|}
\hline & $\begin{array}{l}\text { "Recebê-lo, quando comemoramos } 130 \text { anos da imigração } \\
\text { árabe, renova os laços de confiança e esperança que } \\
\text { fizeram homens e mulheres atravessarem oceanos em } \\
\text { busca de uma nova vida. São, hoje, mais de } 2 \text { milhões e } \\
\text { meio de homens e mulheres } 62 \text { " (MRE, 2010a). } \\
\text { “Temos algo como } 10 \text { milhões de descendentes de } \\
\text { libaneses no Brasil; temos também importante } \\
\text { comunidade judaica” (AMORIM, 2011:70). } \\
\text { "Temos uma vasta comunidade de origem libanesa no } \\
\text { Brasil” (AMORIM, 2011:188). } \\
\text { "Com aproximadamente 10 milhões de descendentes de } \\
\text { árabes no Brasil, nunca um governante brasileiro, no } \\
\text { exercicio do cargo, havia feito uma visita oficial ao } \\
\text { Oriente Médio”. (AMORIM, 2011: 416). }\end{array}$ \\
\hline $\begin{array}{l}\text { Contribuição valorativa } \\
\text { de herança árabe e } \\
\text { judaica para a formação } \\
\text { da identidade brasileira; } \\
\text { valores comuns }\end{array}$ & $\begin{array}{l}\text { "Países árabes e Brasil têm profundos vínculos históricos } \\
\text { e culturais (...). Eles explicam a cordialidade e o respeito } \\
\text { com que nos relacionamos } 63 \text { " (MRE, 2003b). } \\
\text { "A adaptação dos imigrantes às condições da terra que os } \\
\text { acolheu equivale à capacidade da população brasileira de } \\
\text { impregnar-se com seus valores e costumes } 64 \text { " (MRE, } \\
2003 b) . \\
\text { "No Brasil, somos orgulhosos de nosso patrimônio } \\
\text { cultural árabe, que é, hoje, parte de nossa identidade } \\
\text { nacional" (MRE, 2003b). } \\
\text { "Gente empreendedora, laboriosa e valente, que se lançou } \\
\text { em busca de novos horizontes e realizações. Os primeiros } \\
\text { libaneses que chegaram ao Brasil trouxeram não apenas } \\
\text { sua força de trabalho e vontade de vencer, trouxeram sua } \\
\text { determinação em lutar por uma sociedade justa, onde } \\
\text { todos tivessem o direito de progredir por conta do próprio } \\
\text { esforço. Ao longo de todos esses anos, os libaneses } \\
\text { ajudaram a moldar a nossa cultura, integrando-se a todas } \\
\text { as esferas da sociedade brasileira } 66 \text { " (MRE, 2003b). }\end{array}$ \\
\hline
\end{tabular}

${ }^{62}$ Discurso do Presidente Luiz Inácio Lula da Silva por ocasião da visita do Presidente da Síria, Bashar Al-Assad. Brasília, 30 de junho de 2010.

${ }^{63}$ Discurso do Presidente Lula por ocasião da visita à sede da Liga dos Estados Árabes. Cairo, 9 de dezembro de 2003.

${ }^{64}$ Nota à imprensa. Visita do Presidente Luiz Inácio Lula da Silva a Países Árabes. Brasília, 2 de dezembro de 2003.

${ }^{65}$ Discurso do Presidente Lula durante jantar oferecido pelo Presidente da Síria, Bashar Al-Assad. Damasco, 3 de dezembro de 2003.

${ }^{66}$ Discurso do Presidente Lula no plenário da Assembleia Nacional Libanesa, em Beirute, 5 de dezembro de 2003. 


\begin{tabular}{|c|c|}
\hline & 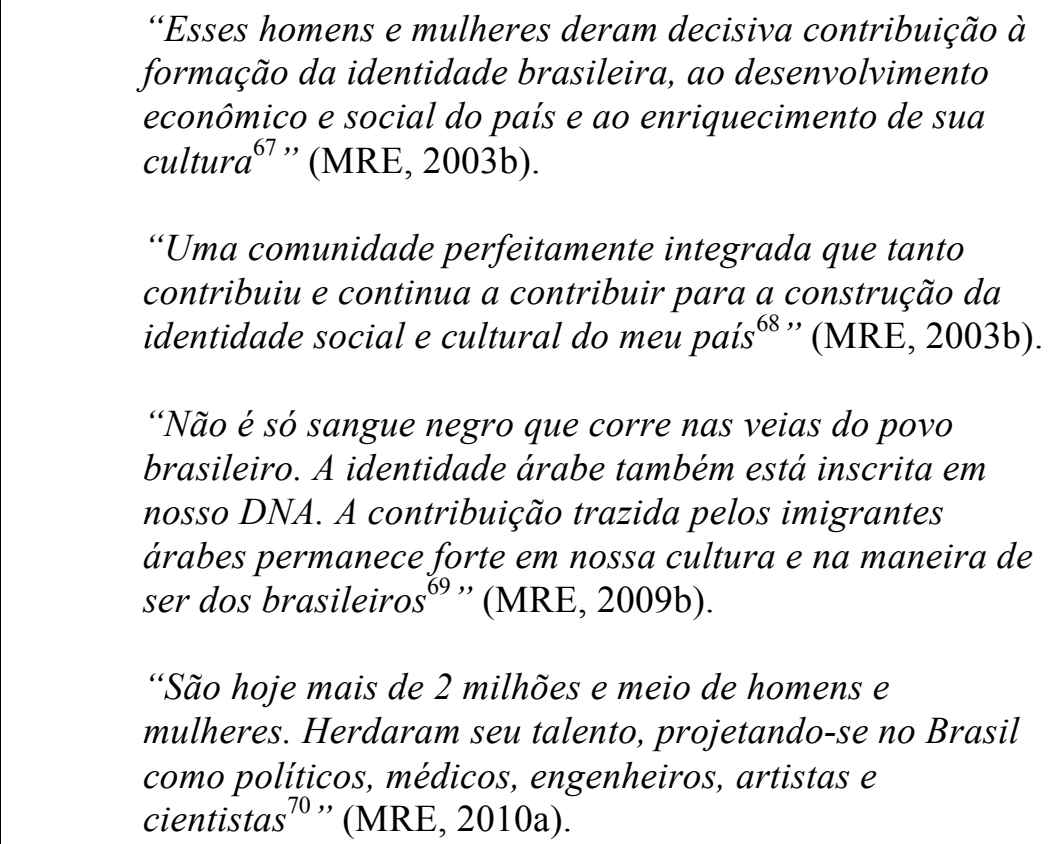 \\
\hline
\end{tabular}

\subsection{O Brasil como defensor da paz e dos direitos humanos}

Um dos principais papéis autopromovidos pelo governo brasileiro ao Oriente Médio durante o governo Lula foi o de defensor da paz e dos direitos humanos. Em discurso de improviso feito a empresários de Israel, em março de 2010, o Presidente Lula, ao lado do Presidente Shimon Peres, exibiu credenciais como especialista em diálogo e afirmou que o Brasil possuía, em seu DNA, o "vírus da paz "71".

De forma análoga, o chanceler Celso Amorim, logo no primeiro discurso por ocasião de sua posse como ministro das Relações Exteriores, no Palácio do Itamaraty, em $1^{\circ}$ de janeiro de 2003, ressaltou o papel da PEB como defensora da paz: “Coerentemente com os anseios manifestados nas urnas, o Brasil terá uma política externa voltada para o desenvolvimento e para a paz". Temas polêmicos, como a

\footnotetext{
${ }^{67}$ Discurso do Presidente Lula por ocasião da visita à sede da Liga dos Estados Árabes, no Cairo, em 9 de dezembro de 2003.

${ }^{68}$ Discurso do Presidente Lula durante jantar oferecido pelo Presidente da Síria, Bashar Al-Assad. Damasco, 3 de dezembro de 2003.

${ }^{69}$ Declaração do Presidente Luiz Inácio Lula da Silva à imprensa por ocasião da visita do Presidente da Autoridade Nacional Palestina, Mahmoud Abbas, a Salvador, BA, em 20 de novembro de 2009.

${ }^{70}$ Discurso do Presidente Luiz Inácio Lula da Silva por ocasião da visita do Presidente da Síria, Bashar Al Assad. Brasília, em 30 de junho de 2010.

${ }^{71} \mathrm{http}: / / w w w . b b c . c o . u k / p o r t u g u e s e /$ noticias/2010/03/100315_lula_virus_paz_ss_vdm.shtml, acessado em 12 de agosto de 2014.
} 
invasão do Iraque pelos Estados Unidos em 2003 e a Questão Israel-Palestina, foram tratados pelo governo brasileiro sob a ótica da paz e dos direitos humanos para a região do Oriente Médio.

No primeiro ano da gestão de Lula, por exemplo, a situação no Iraque foi um dos principais temas da política internacional contemporânea, e o Brasil, consequentemente, posicionou-se de forma oficial sobre a questão, defendendo a manutenção da paz na região e a solução pacífica para a crise, além de lamentar o início da ação militar sem a autorização expressa do CSNU (MRE, 2003a). O papel do Brasil como agente promotor da paz foi bem expresso em discurso do representante permanente alterno do Brasil junto às Nações Unidas, embaixador Luiz Tupy Caldas de Moura, no CSNU, em Nova Iorque, em 11 de março de 2003:

\footnotetext{
"Senhor Presidente, a posição do povo e do Governo brasileiro é bem conhecida. O Iraque deve ser desarmado por meios pacíficos. O Brasil mantém-se pronto para cooperar com qualquer iniciativa voltada para encontrar uma solução pacífica para a crise" (MRE, 2003a, grifo nosso).
}

Ao posicionar-se com relação à paz e aos direitos humanos no que diz respeito à questão Israel-Palestina e à situação na Faixa de Gaza, o ministro Celso Amorim anunciou certa impaciência da PEB em relação à Israel e à divisão sectária entre os palestinos. Segundo Amorim (2011:204), "não haverá paz na região se não houver reconciliação entre os palestinos e um cessar-fogo de maneira efetiva". Em janeiro de 2009, ademais, o Brasil subscreveu pedido de realização de Sessão Especial do Conselho sobre a situação dos direitos humanos na Faixa de Gaza (MRE, 2009a).

Algumas questões pontuais em relação à situação dos direitos humanos no Oriente Médio foram tratadas pelo governo brasileiro durante a gestão de Lula e Celso Amorim. Em maio de 2010, por exemplo, o chanceler manifestou, oficialmente, sua satisfação por ocasião da libertação da estudante francesa Clotilde Reiss, presa no Irã, em julho de 2009, sob acusação de espionagem (AMORIM, 2011). Poucos meses depois, em agosto de 2010, o embaixador do Brasil em Teerã à época, Antonio Salgado, reuniu-se com o vice-ministro interino para as Américas do Ministério das Relações Exteriores do Irã, a fim de transmitir, oficialmente, o apelo referente à cidadã iraniana Sakineh Mohammadi Ashtiani, condenada à sentença de morte por apedrejamento, e a oferta do Brasil em recebê-la, feitos pelo Presidente Luiz Inácio Lula da Silva (MRE, 2010b). 
Algumas incoerências são percebidas, ao examinar o discurso diplomático brasileiro sobre os posicionamentos adotados com relação aos direitos humanos na região do Oriente Médio. O fato de o Brasil, por exemplo, ter-se abstido no Conselho de Direitos Humanos sobre a situação iraniana, durante o segundo mandato do governo Lula e os contrastes de posicionamento adotados entre a firme condenação com respeito à Líbia e a retórica politicamente correta com respeito à Síria fizeram que a PEB do governo Lula fosse alvo de fortes críticas internas e internacionais.

\subsection{A expressão prática da defesa da paz e dos direitos humanos: o Brasil como agente promotor de assistência humanitária internacional}

A projeção, pelo governo brasileiro, do papel de agente promotor de assistência humanitária na região do Oriente Médio pode ser considerada expressão prática do papel anteriormente mencionado do Brasil como defensor da paz e dos direitos humanos. O envolvimento ativo do Brasil na temática de prestação de assistência humanitária internacional iniciou-se no governo Lula, em 2004, com a criação de Coordenação-Geral de Ações Internacionais de Combate à Fome (CGFOME), na estrutura do Ministério das Relações Exteriores (MRE).

A instalação da referida Coordenação teve por missão dar execução a projetos e missões humanitárias internacionais realizadas pelo Brasil, além de coordenar a PEB na área de segurança alimentar e nutricional. Até 2004, as operações humanitárias do Brasil eram pontuais e não estavam organizadas de forma sistemática e continuada. A crise do Líbano, em 2006, por exemplo, foi considerada pelos executores da PEB como marco na prestação de assistência humanitária pelo governo brasileiro, dada a complexidade das operações envolvidas de envio de medicamentos, alimentos e, principalmente, de retirada de brasileiros das regiões do conflito armado.

De acordo com o ministro Milton Rondó Filho, chefe da CGFOME desde a sua criação, em entrevista acerca da política brasileira de cooperação humanitária internacional $^{72}$, concedida ao canal de televisão NBR em 17 de fevereiro de 2013, o início efetivo da projeção do papel do Brasil como promotor de assistência humanitária internacional localiza-se, temporalmente, com o início das operações brasileiras em face do conflito militar ocorrido no Líbano, em julho de 2006:

\footnotetext{
${ }^{72}$ Entrevista disponível em $<$ https://www.youtube.com/watch?v=OhquiTl6c0A $>$. Acesso em 18 de agosto de 2013.
} 
A cooperação humanitária, por parte do governo brasileiro, é bastante recente. Ela se inicia de forma efetiva e continuada em 2006 (...). Com a crise do Líbano, de 2006, nós nos demos conta de que precisávamos organizar essa cooperação; até porque foi uma crise de grandes dimensões e que atingiu grande número de brasileiros. Nós tivemos de retirá-los para a Síria, para a Turquia, depois, trazê-los de avião para cá. Uma operação bastante complexa. E aí percebemos que necessitávamos de recursos para isso também (RONDÓ, 2013).

As palavras do ministro Celso Amorim, por ocasião de encontro com representantes da comunidade libanesa no Clube Monte Líbano, em São Paulo, sustentam o argumento do ministro Rondó segundo o qual o conflito no Líbano foi essencial para o início da prestação de assistência humanitária sistematizada e continuada por parte do Brasil. De acordo com Amorim, a retirada dos 2.950 brasileiros do Líbano, em julho de 2006, foi a maior operação de resgate empreendida pelo governo do Brasil em zona de conflito. Dessas pessoas, 2.678 foram transportadas em 14 voos da Força Aérea Brasileira (FAB) e em 4 voos pelas companhias aéreas privadas TAM, GOL, BRA e VARIG (MRE, 2006b).

O chanceler Celso Amorim foi o segundo ministro das Relações Exteriores a visitar Beirute depois do cessar-fogo, em agosto de 2006, levando consigo medicamentos e doações feitas pelo governo brasileiro e pela comunidade libanesa no Brasil (MRE, 2007a). Em palestra a alunos do Instituto Rio Branco (IRBr), em 4 de agosto de 2010, intitulada "O novo papel do Brasil no mundo", o ministro Amorim relata sua experiência em participar da operação brasileira de entrega de assistência humanitária ao Líbano recém-bombardeado (AMORIM, 2011:330):

Cheguei 24 horas depois do cessar-fogo, em 15 de agosto daquele ano. Foi muito marcante para mim, logo depois da Copa do Mundo que perdemos. Ao chegar ao aeroporto, que só tinha meia pista - pude chegar lá, porque estávamos em um Hércules, um avião preparado para pousar em pistas pequenas -, vi fumaça em vários lugares da cidade. Fui imediatamente para o sul de Beirute, que tinha sido a área mais bombardeada. Curiosamente (e tragicamente), metade dos bombardeios em Beirute ocorreu entre a declaração e a efetivação do cessar-fogo, 48 horas depois (...). Cheguei lá na terça-feira. Havia ainda muitos destroços. Minha então chefe de gabinete, a embaixadora Maria Nazareh - hoje embaixadora em Genebra para a parte política - me chamou a atenção para as camisetas e as bandeiras do Brasil no meio dos escombros. Eram brasileiros (ou pelo menos "brasileiros de coração") que estavam lá. Isso mostra que o conflito, até emocionalmente, estava muito mais próximo de nós do que as pessoas às vezes supõem (...). Essas coisas tocam, fazem parte da nossa maneira de atuar e de ver o mundo. Às vezes, a política externa pode parecer uma coisa muito conceitual, muito fria e distante, mas não é assim" (AMORIM, 2011:330). 
Além da operação de resgate dos brasileiros que se encontravam na região conflituosa entre Líbano e Israel, o Governo brasileiro efetuou, em paralelo, entrega de doação de 4,2 toneladas de medicamentos fornecidos pelo Ministério da Saúde (MS) e 5,2 toneladas de alimentos doados pela Companhia Nacional de Abastecimento (CONAB) e pela colônia libanesa em São Paulo ${ }^{73}$ (CGFOME, 2011). Financeiramente, o Brasil contribuiu com o montante de US\$ 1.500.000,00 para a reconstrução do Líbano, em dois momentos distintos.

A primeira doação, de US\$ 500.000, ocorreu em agosto de 2006, durante participação do embaixador brasileiro para o Oriente Médio, Afonso de Ouro-Preto, na Conferência Internacional de Doadores para o Líbano, promovida pelo governo da Suécia. A segunda doação, de US\$ 1.000.000, foi em janeiro de 2007, por ocasião da participação do Brasil na Conferência Internacional de Paris de Apoio ao Líbano ("Paris III"). O Governo brasileiro vangloriou-se, por ter sido o único país latinoamericano convidado pelo governo francês a participar da referida Conferência ${ }^{74}$ (MRE, 2007a).

No período de junho de 2006 a julho de 2010, por exemplo, foram enviadas ao Líbano, além de quase 10 toneladas de medicamentos e mantimentos, doações financeiras no valor total estimado em US\$ 2.209.688. Muitas doações humanitárias para o Líbano foram realizadas por meio de conferências internacionais e pelas Nações Unidas, em especial, nesse domínio, pela Agência das Nações Unidas para Refugiados Palestinos. Essa iniciativa objetivou o apoio a ações emergenciais de reconstrução do país, o financiamento de projetos de cooperação entre o Brasil e o Líbano e o suporte para a reconstrução de campo de refugiados palestinos localizado no território libanês (CGFOME, 2011).

A maior parte da assistência humanitária prestada pelo governo brasileiro para o Oriente Médio, no entanto, concentrou-se na região geográfica da Palestina, dos Territórios Palestinos Ocupados e da Faixa de Gaza. As doações monetárias para fins de assistência humanitária e as doações de alimentos e de medicamentos para a região geográfica da Palestina corroboram uma das principais metas da PEB do governo Lula, mencionada no primeiro capítulo, que é a defesa da criação de um Estado

\footnotetext{
${ }^{73}$ Dados retirados do Balanço 2006-2010, da Coordenação-Geral de Ações Internacionais de Combate à Fome (CGFOME), do Ministério das Relações Exteriores. Relatório. Brasília, 2011.

${ }^{74}$ Nota à imprensa. "Participação do Ministro Celso Amorim na Conferência Internacional de Paris de Apoio ao Líbano" (24 de janeiro de 2007).
} 
palestino independente, democrático, coeso e economicamente viável, convivendo em paz e em segurança com Israel ${ }^{75}$ (MRE, 2010b).

De acordo com relatório da CGFOME sobre o balanço-geral da assistência humanitária prestada pelo Brasil, no período entre agosto de 2006 e abril de 2010, $58,82 \%$ de toda a ajuda humanitária efetuada pelo Brasil para o Oriente Médio foram direcionados à região geográfica da Palestina, dos Territórios Palestinos Ocupados e da Faixa de Gaza, o que significou 10 do total de 17 doações humanitárias realizadas nesse período. No total, o governo brasileiro doou US\$ 15.415.000,00 em contribuições financeiras à região da Palestina, em sua maioria, realizadas por meio de Conferências Internacionais de Doadores ou de Agências Especializadas das Nações Unidas, como, por exemplo, a Agência das Nações Unidas para Assistência a Refugiados Palestinos no Oriente Médio (UNRWA), a Estratégia Internacional das Nações Unidas para Redução de Desastres (UNISDR) ou a Instituição Global para Redução de Desastres e Resgate (GFDRR).

O restante da ajuda humanitária para o Oriente Médio prestada pelo governo brasileiro durante as duas gestões do Presidente Lula concentrou-se no Líbano $(29,41 \%)$, no Irã $(5,88 \%)$ e no Iraque $(5,88 \%)$. O Líbano, considerado pela diplomacia brasileira como o principal fator motivacional para a criação de mecanismo governamental de ajuda humanitária organizado, sistematizado e institucionalizado, foi responsável por 5 entre as 17 principais operações e doações humanitárias realizadas pelo Brasil durante o governo Lula (CGFOME, 2011). A ajuda prestada ao Irã ocorreu em julho de 2010 e foi bastante pontual: o Brasil doou US\$ 500.000, por meio do Alto Comissariado das Nações Unidas para Refugiados (ACNUR), à assistência humanitária a refugiados no Irã. Com relação ao Iraque, o Governo brasileiro ofertou, entre julho e agosto de 2010, US\$ 500.000, para fortalecer a alimentação escolar iraquiana e financiar ações de reparação e reconstrução de escolas, inclusive em campo de refugiados (CGFOME, 2011).

Outras ações, para além das doações humanitárias per se, ocorreram em prol da projeção do papel de agente promotor de assistência humanitária durante o governo Lula. A instalação da Comissão Nacional para Difusão e Implementação do Direito Humanitário no Brasil, em novembro de 2007, e a inauguração do Armazém Humanitário brasileiro no Aeroporto Internacional Antonio Carlos Jobim, no Rio de

\footnotetext{
${ }^{75}$ Nota à imprensa. "Retomada do diálogo direto entre israelenses e palestinos" (25 de agosto de 2010).
} 
Janeiro, em fevereiro de 2009, são alguns exemplos (MRE, 2007; 2010). A Comissão Nacional para Difusão e Implementação do Direito Humanitário no Brasil objetiva propor a autoridades competentes medidas necessárias à implantação e à difusão do direito humanitário no Brasil, notadamente, as Convenções de Genebra de 1949 e os Protocolos Adicionais I e II de $1947^{76}$. A instalação do Armazém Humanitário no aeroporto do Rio de Janeiro, por sua vez, teve como objetivo dar maior celeridade à assistência humanitária internacional prestada pelo Brasil, de forma a tornar disponível o estoque permanente de 14 toneladas de alimentos para pronta doação a populações atingidas por calamidades, guerras ou desastres naturais ${ }^{77}$.

O papel nacional de agente promotor de assistência humanitária internacional foi um dos principais nas concepções da política externa brasileira do governo Lula. Atualmente, conforme mencionou o chefe da CGFOME em entrevista recente, o Brasil é um dos principais países cooperantes humanitários internacionais, estando entre os 8 que mais contribuíram com doações para o Programa Mundial de Alimentos da ONU (PMA). É necessário levar em consideração, no entanto, que todas as doações humanitárias internacionais se revestem de interesses de poder. A decisão de doar ou não é baseada em critérios políticos. No caso das doações do Brasil para o Oriente Médio, percebe-se maior peso político às doações para a região da Palestina e para os Territórios Ocupados em relação a outras regiões do Oriente Médio.

Compreende-se, dessa maneira, que as principais mensagens políticas que o governo brasileiro transmitiu por ocasião de ajudas humanitárias internacionais para a região do Oriente Médio foram: posição da PEB em relação à questão palestina; favorecimento da inclusão de novos atores internacionais para a discussão de questões afetas ao Oriente Médio; fim de obstáculos ao fluxo de assistência humanitária para regiões em crise. Sobre a posição brasileira em relação à Questão palestina, por exemplo, o ministro Celso Amorim aproveitou a ocasião da Conferência Internacional em Apoio à Economia Palestina para a Reconstrução de Gaza, em 2 de março de 2009, no Egito, para posicionar-se em nome do Estado brasileiro:

\footnotetext{
${ }^{76}$ Nota à imprensa. "Instalação da Comissão Nacional para Difusão e Implementação do Direito Humanitário no Brasil”. Brasília, 11 de fevereiro de 2004.

${ }^{77}$ Nota à imprensa. "Inauguração de Armazém Humanitário do Governo brasileiro no Aeroporto Internacional Antonio Carlos Jobim”. Brasília, 25 de fevereiro de 2009.
} 
É fundamental trazer melhorias ao dia a dia dos cidadãos comuns na Palestina, e, para tanto, a dignidade moral é tão importante quanto as condições materiais (...). Devem ser imediatamente interrompidos os graves obstáculos à solução da coexistência dos dois Estados, de que são exemplos a expansão dos assentamentos por Israel e o frequente uso da força (MRE, 2009a).

Quanto à inclusão de novos atores para a discussão e a mediação de assuntos relativos ao Oriente Médio, o chanceler brasileiro, na mesma ocasião, destacou:

O Brasil acredita que todos os atores relevantes na região que estejam preparados para agir de forma construtiva devem ter uma chance de participar no processo. Incorporar às discussões países em desenvolvimento de fora da região também daria mais legitimidade e traria novas ideias às conversações de paz. O Brasil encoraja a convocação de uma conferência em seguimento à reunião de Annapolis (MRE, 2009a).

Os pronunciamentos que se seguem ao momento das doações, dessa forma, podem ser considerados como estratégia encontrada pelo governo brasileiro, para atingir objetivos políticos, como, por exemplo, conseguir o apoio de países ou blocos a candidaturas brasileiras a cargos em organismos internacionais multilaterais, como a FAO ou a OMC, ou a posições políticas, como a cadeira permanente no CSNU. A análise dos discursos de autoridades em política externa brasileira e do Presidente Lula, exposta na tabela 4, evidencia a característica da PEB de valer-se do momento das doações humanitárias para ganhar empatia de seus interlocutores, projetar novos papéis para o Brasil e, em especial, delimitar posicionamentos-chave da $\mathrm{PEB}^{78}$.

Tabela 4: Assistência humanitária prestada pelo Brasil a países do Oriente Médio por ordem cronológica

\begin{tabular}{|c|c|c|c|}
\hline País & Motivo & Doação & Data \\
\hline 1. Líbano & $\begin{array}{l}\text { Conflito armado. Retirada de } \\
\text { cerca de } 3 \text { mil brasileiros em voos } \\
\text { da FAB, a partir de Adana, na } \\
\text { Turquia, em colaboração com as } \\
\text { empresas de aviação civil TAM, } \\
\text { GOL e VARIG, que resgataram } \\
\text { brasileiros em Damasco, na Síria. } \\
\text { Organização de comboios de } \\
\text { ônibus para evacuação de } \\
\text { brasileiros por terra do Vale do } \\
\text { Bekaa até Adana ou Damasco. }\end{array}$ & $\begin{array}{l}\text { Doação de } 4,2 \mathrm{t} \text { de } \\
\text { medicamentos } \\
\text { fornecidos pelo } \\
\text { Ministério da Saúde. } \\
\text { Transporte de } 5,2 \mathrm{t} \\
\text { de mantimentos e } \\
\text { alimentos angariados } \\
\text { pela colônia libanesa } \\
\text { em São Paulo, no } \\
\text { último avião de } \\
\text { resgate enviado pela } \\
\text { VARIG }\end{array}$ & $\begin{array}{l}\text { Junho-agosto } \\
\text { de } 2006\end{array}$ \\
\hline
\end{tabular}

\footnotetext{
${ }^{78}$ Elaboração com base em relatório sobre a cooperação humanitária internacional prestada pelo Brasil entre os anos de 2006 e de 2010 da Coordenação-Geral de Ações Internacionais de Combate à Fome.

${ }^{79} \mathrm{O}$ ministro Celso Amorim fez, pessoalmente, a entrega dos medicamentos, que incluíam antirretrovirais, antibióticos e 16 kits de farmácia básica, suficientes para o atendimento das
} 


\begin{tabular}{|c|c|c|c|}
\hline 2. Líbano & $\begin{array}{l}\text { Conferência Internacional de } \\
\text { Doadores para o Líbano, } \\
\text { promovida pelo governo da } \\
\text { Suécia. }\end{array}$ & $\begin{array}{l}\text { O Governo } \\
\text { brasileiro, por meio } \\
\text { do embaixador } \\
\text { extraordinário para o } \\
\text { Oriente Médio, } \\
\text { Affonso Celso de } \\
\text { Ouro-Preto, anunciou } \\
\text { contribuição de US\$ } \\
500 \text { mil para ações } \\
\text { emergenciais de } \\
\text { reconstrução do } \\
\text { Líbano por meio do } \\
\text { PNUD. }\end{array}$ & $\begin{array}{l}\text { Agosto de } \\
2006\end{array}$ \\
\hline $\begin{array}{l}\text { 3. Territórios } \\
\text { Palestinos } \\
\text { Ocupados }\end{array}$ & $\begin{array}{l}\text { Conferência Internacional sobre a } \\
\text { Situação Humanitária nos } \\
\text { Territórios Palestinos Ocupados } \\
\text { (TPO), organizada em parceria } \\
\text { com os governos da Espanha e da } \\
\text { Noruega. }\end{array}$ & $\begin{array}{l}\text { A delegação do } \\
\text { Brasil, chefiada pelo } \\
\text { embaixador } \\
\text { extraordinário para o } \\
\text { Oriente Médio, } \\
\text { Affonso Celso de } \\
\text { Ouro-Preto, anunciou } \\
\text { contribuição de US\$ } \\
500 \text { mil para projetos } \\
\text { humanitários da } \\
\text { ONU aos Territórios } \\
\text { Palestinos Ocupados. }\end{array}$ & $\begin{array}{l}\text { Agosto de } \\
2006\end{array}$ \\
\hline 4. Líbano & $\begin{array}{l}\text { Conferência Internacional de } \\
\text { Paris de Apoio ao Líbano }{ }^{80} \\
\text { ("Paris III”). Financiamento de } \\
\text { projetos brasileiros de cooperação } \\
\text { com o Líbano. }\end{array}$ & US\$ 1 milhão & $\begin{array}{l}\text { Janeiro de } \\
2007\end{array}$ \\
\hline $\begin{array}{l}\text { 5. Conferência de } \\
\text { Doadores para os } \\
\text { Territórios } \\
\text { Palestinos (Paris) }\end{array}$ & $\begin{array}{l}\text { Apoio da comunidade } \\
\text { internacional à retomada do } \\
\text { processo de paz, ao crescimento } \\
\text { da atividade econômica nos } \\
\text { territórios palestinos e ao } \\
\text { fortalecimento institucional da } \\
\text { Autoridade Nacional Palestina } \\
\text { (ANP). }\end{array}$ & $\begin{array}{l}\text { O Brasil, juntamente } \\
\text { com seus parceiros } \\
\text { do Foro de Diálogo } \\
\text { IBAS, anunciou } \\
\text { contribuição no valor } \\
\text { de US\$ } 1 \text { milhão } \\
\text { para projetos } \\
\text { voltados à } \\
\text { capacitação } \\
\text { institucional e à } \\
\text { recuperação da } \\
\text { infraestrutura nos } \\
\text { territórios palestinos. }\end{array}$ & $\begin{array}{l}\text { Dezembro de } \\
2007\end{array}$ \\
\hline
\end{tabular}

necessidades emergenciais de 145 mil pessoas. Além disso, o chanceler manteve diálogo com autoridades locais e trocou impressões sobre as perspectivas de solução do conflito no Líbano.

${ }^{80} \mathrm{O}$ Brasil foi o único país latino-americano convidado pelo Governo francês a participar da Conferência de Paris. 


\begin{tabular}{|c|c|c|c|}
\hline 6. Palestina & $\begin{array}{l}\text { Conflito armado. Aprovação de } \\
\text { projetos de assistência } \\
\text { humanitária ao povo palestino nas } \\
\text { áreas de reconstrução e } \\
\text { reabilitação. }\end{array}$ & R\$ 17 milhões & $\begin{array}{l}\text { Dezembro de } \\
2007\end{array}$ \\
\hline 7. Líbano & $\begin{array}{l}\text { Contribuição voluntária à Agência } \\
\text { das Nações Unidas para } \\
\text { Refugiados Palestinos (UNRWA) } \\
\text { à reconstrução de campo de } \\
\text { refugiados palestinos no Líbano. }\end{array}$ & $\mathrm{R} \$ 471.800,00$ & $\begin{array}{l}\text { Junho de } \\
2008\end{array}$ \\
\hline 8. Palestina & $\begin{array}{l}\text { Contribuição à UNRWA para } \\
\text { reconstrução e recuperação do } \\
\text { campo de refugiados de Nahr- El } \\
\text { Bared. }\end{array}$ & US\$ 200.000 & $\begin{array}{l}\text { Dezembro de } \\
2008\end{array}$ \\
\hline $\begin{array}{l}\text { 9. Palestina } \\
\text { (Gaza) }\end{array}$ & $\begin{array}{l}\text { Conflitos armados. Envio de } \\
\text { aeronave com } 6 \mathrm{t} \text { de } \\
\text { medicamentos (cedidos pelo MS e } \\
\text { pelo Laboratório Farmacêutico da } \\
\text { Aeronáutica) e } 8 \mathrm{t} \text { de alimentos } \\
\text { (cedidos pela CONAB) }^{81} \text {. } \\
\text { Doação às pessoas afetadas pelo } \\
\text { conflito na Faixa de Gaza. }\end{array}$ & $\begin{array}{l}6 \mathrm{t} \text { de } \\
\text { medicamentos } \\
\text { de alimentos } \\
\text { 83 }\end{array}$ & $\begin{array}{l}\text { Janeiro de } \\
2009\end{array}$ \\
\hline $\begin{array}{l}\text { 10. Reconstrução } \\
\text { de Gaza }\end{array}$ & $\begin{array}{l}\text { Conferência Internacional em } \\
\text { apoio à economia palestina e para } \\
\text { a reconstrução de Gaza. Sharm } \\
\text { El-Sheik, Egito. }\end{array}$ & $\begin{array}{l}\text { US \$ } 10 \text { milhões para } \\
\text { a reconstrução de } \\
\text { Gaza }^{84}\end{array}$ & $\begin{array}{l}\text { Março de } \\
2009\end{array}$ \\
\hline $\begin{array}{l}\text { 11. Palestina/ } \\
\text { UNWRA }\end{array}$ & $\begin{array}{l}\text { Contribuição voluntária à Agência } \\
\text { das Nações Unidas para } \\
\text { Refugiados Palestinos no Oriente } \\
\text { Médio (UNRWA), para garantir a } \\
\text { segurança alimentar de escolares. }\end{array}$ & US\$ $200.000,00$ & $\begin{array}{l}\text { Fevereiro de } \\
2010\end{array}$ \\
\hline
\end{tabular}

\footnotetext{
${ }^{81}$ Os alimentos foram destinados a dois abrigos de emergência, ambos administrados pela ONU e ocupados por centenas de pessoas deslocadas. O carregamento de medicamentos, por sua vez, foi enviado aos hospitais Al-Ahli e Shifa, este o maior da Faixa de Gaza.

${ }^{82}$ A carga de 6 toneladas de medicamentos doados foi composta de hidroclorotiazida (antihipertensivo), sais de reidratação oral, fator 9 (hemoderivado), thiopental sódico (anestésico), glibenclamida (antidiabético), mebendazol (antiparasitário), iodo aquoso (antisséptico), cloridato de alfentanila (anestésico), sulfato de morfina (anestésico), diazepam (ansiolítico) e citrato de fentanila (analgésico).

${ }^{83} \mathrm{O}$ governo brasileiro doou 8 toneladas de alimentos de alto valor calórico e proteico em 350 caixas de produtos prontos para o consumo: sardinha em lata, fiambre bovino em lata, leite em pó, biscoito de água e sal, biscoito de maisena, macarrão instantâneo, farinha de milho em flocos e açúcar cristal.

${ }^{84} \mathrm{Com}$ esse propósito, o Presidente Lula pediu ao Congresso Nacional que autorizasse essa doação com urgência (MRE, 2009a).
} 


\begin{tabular}{|c|c|c|c|}
\hline 12. UN ISDR & $\begin{array}{l}\text { Contribuição voluntária à } \\
\text { Estratégia Internacional das } \\
\text { Nações Unidas para Redução de } \\
\text { Desastres a ações de minimização } \\
\text { de calamidades socioambientais, } \\
\text { relativas aos Territórios Palestinos } \\
\text { Ocupados, ao Sudão e a El } \\
\text { Salvador. }\end{array}$ & US\$ $600.000,00$ & $\begin{array}{l}\text { Abril de } \\
2010\end{array}$ \\
\hline $\begin{array}{l}13 . \\
\text { Global Facility } \\
\text { for Disaster } \\
\text { Reduction and } \\
\text { Recovery - } \\
\text { GFDRR }\end{array}$ & $\begin{array}{l}\text { Contribuição voluntária à Global } \\
\text { Facility for Disaster Reductionand } \\
\text { Recovery (GFDRR- Banco } \\
\text { Mundial) a ações de minimização } \\
\text { de calamidades socioambientais } \\
\text { no Sudão, nos Territórios } \\
\text { Palestinos Ocupados, na } \\
\text { Guatemala e em Moçambique. }\end{array}$ & US\$ $1.500 .000,00$ & $\begin{array}{l}\text { Abril de } \\
2010\end{array}$ \\
\hline $\begin{array}{l}\text { 14. Líbano/ } \\
\text { UNWRA }\end{array}$ & $\begin{array}{l}\text { Contribuição voluntária à } \\
\text { UNRWA (Agência da ONU para } \\
\text { Reconstrução e Obras para } \\
\text { Refugiados Palestinos no Oriente } \\
\text { Médio) para apoio à reconstrução } \\
\text { de campo de refugiados palestinos } \\
\text { no Líbano. }\end{array}$ & US\$ 500.000,00 & $\begin{array}{l}\text { Julho de } \\
2010\end{array}$ \\
\hline 15. Irã/ ACNUR & $\begin{array}{l}\text { Contribuição voluntária ao Alto- } \\
\text { Comissariado das Nações Unidas } \\
\text { para Refugiados (ACNUR) em } \\
\text { assistência humanitária a } \\
\text { refugiados no Irã. }\end{array}$ & US\$ 500.000,00 & $\begin{array}{l}\text { Julho de } \\
2010\end{array}$ \\
\hline $\begin{array}{l}\text { 16. Iraque/PMA/ } \\
\text { UNICEF/ACNUR } \\
\text { / OIM }\end{array}$ & $\begin{array}{l}\text { Contribuição voluntária ao "Plano } \\
\text { de Ação Humanitária para o } \\
\text { Iraque em } 2010 \text { 0", elaborado pelos } \\
\text { órgãos OCHA }{ }^{85}, \text { PMA }^{86} \text {, } \\
\text { UNICEF }^{87}, \text { ACNUR }^{88} \text { e OIM }{ }^{89} \\
\text { com o objetivo de fortalecer a } \\
\text { alimentação escolar iraquiana e } \\
\text { financiar ações de reparação e } \\
\text { reconstrução de escolas, inclusive, } \\
\text { em campos de refugiados. }\end{array}$ & $\begin{array}{l}\text { PMA (US\$ } 250.000) \\
\text { UNICEF (US\$ } \\
100.000) \\
\text { ACNUR (US\$ } \\
100.000) \\
\text { OIM (US\$ 50.000) } \\
\text { Total: US\$ } 500 \text { mil }\end{array}$ & $\begin{array}{l}\text { Julho e } \\
\text { agosto de } \\
2010\end{array}$ \\
\hline
\end{tabular}

\footnotetext{
${ }^{85}$ Escritório das Nações Unidas para a Coordenação de Assuntos Humanitários (OCHA).

${ }^{86}$ Programa Mundial de Alimentos das Nações Unidas (PMA).

${ }^{87}$ Fundo das Nações Unidas para a Infância (UNICEF).

${ }^{88}$ Alto Comissariado das Nações Unidas para Refugiados (ACNUR).

${ }^{89}$ Organização Internacional para as Migrações (OIM).
} 


\begin{tabular}{|c|c|c|c|}
\hline 17. Gaza & $\begin{array}{l}\text { Contribuição voluntária à Agência } \\
\text { das Nações Unidas para } \\
\text { Reconstrução e Obras para } \\
\text { Refugiados Palestinos no Oriente } \\
\text { Próximo (UNRWA), com vistas } \\
\text { ao financiamento de projetos de } \\
\text { reconstrução de Gaza a ser } \\
\text { selecionados pelo Brasil e } \\
\text { acordados com a Autoridade } \\
\text { Nacional Palestina, em } \\
\text { cumprimento ao compromisso } \\
\text { brasileiro assumido na } \\
\text { Conferência Internacional do } \\
\text { Cairo, em Apoio à Economia } \\
\text { Palestina para a Reconstrução de } \\
\text { Gaza, de } 2 / 3 / 2009, \text { conforme } \\
\text { autorizado pela Lei } 12.292 \text { de } \\
\text { 20/7/2010. }\end{array}$ & US\$ $1.000 .000,00$ & $\begin{array}{l}\text { Dezembro de } \\
2010\end{array}$ \\
\hline
\end{tabular}

\subsection{O Brasil como criador de novos arranjos políticos, diplomáticos e econômicos alternativos ao status quo}

O quarto papel projetado pelo governo brasileiro durante a gestão de Luiz Inácio Lula da Silva em relação aos países do Oriente Médio foi o de criador de novos arranjos políticos, diplomáticos e econômicos ou, conforme define Holsti (1970), o de agente antistatus quo. De acordo com Holsti, que formulou sua teoria à época da Guerra Fria, (1970:264), “quando o status quo imperialista é percebido como ameaça séria, muitos países - não necessariamente apenas aqueles comunistas - concebem a si próprios como agentes da luta contra esse demônio ${ }^{90 "}$. De acordo com a National Role Theory, as principais fontes da concepção nacional do papel de agente antistatus quo são alguns princípios de ideologia, percepção de ameaça externa e atitudes anticolonialistas (HOLSTI, 1970:296). Defende-se, nesta pesquisa, a hipótese de que o Brasil, ao lançar a ideia da Cúpula América do Sul-Países Árabes (ASPA) e ao incentivar uma série de acordos comerciais entre o MERCOSUL e diversos países do Oriente Médio, objetivou criar novos arranjos políticos, diplomáticos e comerciais que contrabalançassem o poder das tradicionais potências, ou seja, do status quo do sistema internacional contemporâneo de poder.

\footnotetext{
${ }^{90}$ Tradução nossa. "Where imperialism is perceived as a serious threat, many governments - by no means limited to communist party - see themselves as agents of 'struggle' against this evil" (HOLSTI, 1970:264).
} 


\subsubsection{A Cúpula América do Sul - Países Árabes (ASPA)}

A ideia de criação de um fórum de diálogo que reunisse países da América do Sul e do Oriente Médio com o objetivo de contrabalançar o peso das potências tradicionais surgiu no início do governo Lula, em 2003, quando o Presidente fez sua primeira visita oficial ao mundo árabe e expôs a intenção de realizar cúpula que congregasse ambos os continentes (MRE, 2005a; 2008a). Em palestra ministrada no Instituto Rio Branco (IRBr) acerca das relações entre Brasil-Oriente Médio, no dia 7 de outubro de 2010, o então chanceler Celso Amorim narrou o nascimento da ideia da Cúpula América do Sul-Países Árabes (ASPA) por parte do Presidente Lula:

\footnotetext{
Foi assim que nasceu a ideia da Cúpula América do Sul - Países Árabes, ASPA, em uma conversa com o Presidente Lula sobre a necessidade de diversificar as relações. Creio que o professor Marco Aurélio também estava presente na cabine do avião presidencial. O Presidente Lula sugeriu: "Vamos criar algum mecanismo" - encontros de chefes de Estado - "entre o Brasil e os países árabes". Como estávamos empenhados a fundo, no processo de integração sul-americana, ponderei: "Presidente, já que estamos nessa empreitada de integração sul-americana, por que não fazemos América do Sul - Países Árabes?". É claro que isso nos deu muito mais trabalho. Esse formato tem força de atração maior. E acho que para a América do Sul foi muito importante (...). Portanto, foi naquele momento, na visita do Presidente Lula ao Oriente Médio, que essa iniciativa foi pensada, ainda sem nome (AMORIM, 2011:416-417).
}

Por meio da expressão amplamente difundida de "trabalhar para uma nova geografia econômica do mundo" (AMORIM, 2011:416-417), o Presidente Lula e o chanceler Celso Amorim deixaram claro, à época, a intenção da PEB de buscar novos mercados para os produtos brasileiros, além de fortalecer a dimensão política da Cúpula América do Sul - Países Árabes (ASPA), para criar o contrapoder ao status quo vigente no sistema internacional contemporâneo. Segundo Farah (2008:190), Lula pediu a formação de um "bloco árabe latino-americano" com o intuito de permitir que os países em desenvolvimento pudessem ter mais voz em foros internacionais. Ressalta-se, nesse momento inicial, a repetição da estratégia retórica de remissão a laços afetivos e históricos com países e povos árabes, para justificar e legitimar a realização da referida Cúpula ao público interno e aos países árabes.

A Cúpula América do Sul-Países Árabes é definida pela diplomacia brasileira como mecanismo de cooperação inter-regional e fórum de coordenação políticodiplomática, cujo objetivo é aproximar líderes das duas regiões em busca de 
concertação política, econômica e cultural $^{91}$. Farah (2008:200), de forma análoga, interpreta que o principal objetivo da Cúpula ASPA foi a construção de conhecimento mútuo das sociedades envolvidas. De acordo com o relatório da Secretaria Permanente do Sistema Econômico Latino-Americano (2011), a Cúpula ASPA firmou-se como mecanismo de cooperação birregional e foro de coordenação política para o redescobrimento recíproco de duas regiões que possuem enorme potencial.

A criação do mecanismo, como citado anteriormente, foi proposta pelo Presidente Lula em 2003. Sua formalização, no entanto, ocorreu com a realização da I Cúpula de Chefes de Estado e de Governo da América do Sul e Países Árabes, que ocorreu em Brasília, entre os dias 10 e 11 de maio de 2005. De acordo com Pinto (2013:102), “em 2005, formou-se o bloco inter-regional ASPA, que formalizou, pela primeira vez, relações institucionais entre as duas regiões". Integram a Cúpula ASPA 34 países - 12 Estados sul-americanos ${ }^{92}$ e 22 árabes $^{93}$-, o Secretariado-Geral da Liga dos Estados Árabes (LEA) e o da União das Nações Sul Americanas (UNASUL) ${ }^{94}$.

O Brasil foi escolhido como o coordenador regional sul-americano da ASPA, por haver sediado a I Cúpula e, por decisão dos membros do mecanismo, até que a Secretaria-Geral da UNASUL seja constituída e plenamente operacionalizada, para assumir a representação regional ${ }^{95}$. Pela parte árabe, a coordenação é desempenhada pelo Secretariado-Geral da Liga dos Estados Árabes (LEA). Além das Cúpulas de chefes de Estado e de Governo, a estrutura da ASPA compreende um conselho de chanceleres e um conselho de altos funcionários.

As Cúpulas são realizadas de três em três anos, e as demais instâncias reúnemse a cada dois anos e a cada seis meses, respectivamente, inclusive à margem da Assembleia Geral das Nações Unidas, desde 2009. Ademais do propósito de concertação política, a ASPA visa à cooperação setorial, composta por cinco comitês que atuam nas áreas de ciência e tecnologia, meio ambiente (com subcomitê de

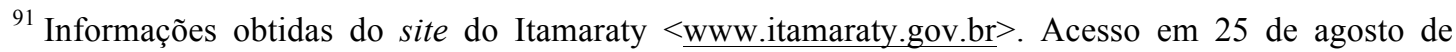
2014.

${ }^{92}$ Fazem parte da Cúpula ASPA os seguintes países sul-americanos: Argentina, Bolívia, Brasil, Chile, Colômbia, Equador, Guiana, Paraguai, Peru, Suriname, Uruguai e Venezuela.

${ }^{93}$ Pelo lado árabe, são membros da Cúpula Árabe: Arábia Saudita, Argélia, Bahrein, Catar, Comores, Djibuti, Egito, Emirados Árabes Unidos, Iêmen, Iraque, Jordânia, Kuait, Líbano, Líbia, Marrocos, Mauritânia, Omã, Palestina, Síria, Somália, Sudão e Tunísia.

${ }^{94}$ Informações obtidas do site do Itamaraty <www.itamaraty.gov.br $>$. Acesso em 25 de agosto de 2014.

${ }^{95}$ Nota à imprensa. "II Cúpula América do Sul - Países Árabes”. Brasília, 28 de março de 2009.
} 
combate à desertificação), cultura, economia e temas sociais ${ }^{96}$ (SELA, 2011; MRE, 2009a:217). A figura 6, a seguir, apresenta o organograma da $\mathrm{ASPA}^{97}$.

Figura 6: Organograma da Cúpula ASPA

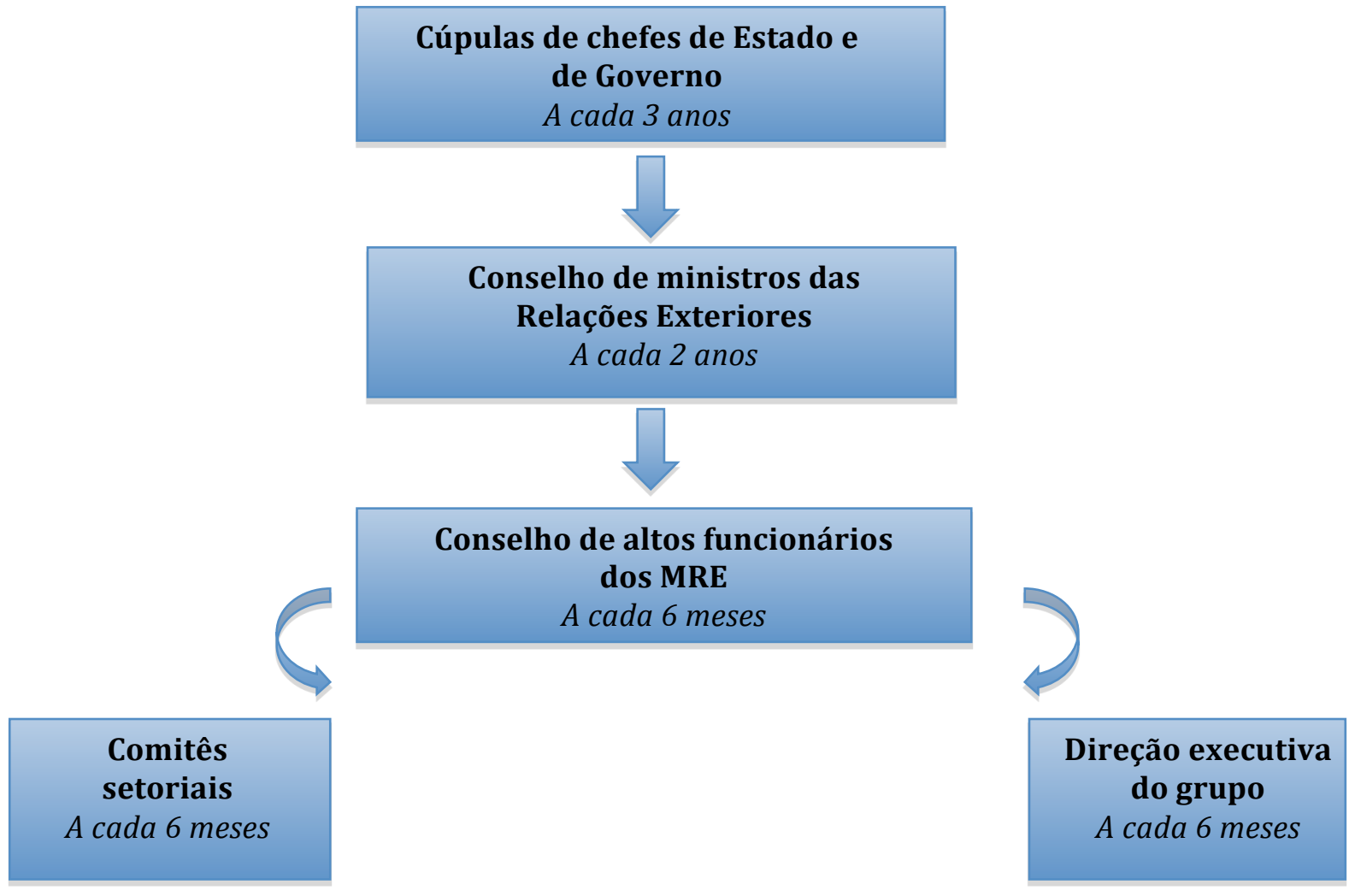

No que diz respeito às expectativas brasileiras em relação à Cúpula ASPA, percebem-se, nos discursos dos formuladores da PEB, sinais de inquietação, euforia e ingenuidade em relação ao alcance político e econômico do fórum multilateral em questão. Conforme Manzur (2011:28-29), alguns obstáculos para a concretização dos objetivos da Cúpula não foram levantados nos discursos oficiais, como, por exemplo, a dificuldade logística em relação aos transportes para comércio e a grande quantidade de temas tratados pela Cúpula, alguns polêmicos, como a conceituação de democracia e de terrorismo. De forma semelhante, o relatório do Sistema Econômico Latino-Americano e do Caribe (2011) alerta para que encontrar pontos de coincidência entre as duas regiões não seja tarefa fácil em razão especial do fato de o Oriente Médio apresentar diferenças políticas internas, baixa integração econômica,

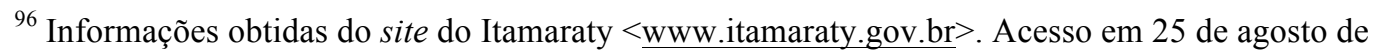
2014.

${ }^{97}$ Elaboração com base em informações obtidas no site do Ministério das Relações Exteriores.
} 
níveis de comércio intrarregional pequenos e incipiente desenvolvimento de instituições democráticas plurais.

Evidencia-se, como exemplifica o discurso do chanceler Celso Amorim acerca de conceitos e ações da política externa do governo do Presidente Lula, em 4 de agosto de 2006, elevado desejo da PEB de reformar as instâncias de governança global, instrumentalizando, dessa forma, a Cúpula ASPA:

\footnotetext{
Vejamos a Cúpula América do Sul - Países Árabes. Acho que esse mecanismo tem a capacidade de mudar, efetivamente, a percepção que as pessoas têm do mundo. Eu disse, à época da Primeira Cúpula, (...), que essa iniciativa era "um movimento de placas tectônicas na política internacional" (AMORIM, 2011:67).
}

O símbolo da ASPA, representado pela lua crescente e pelo cruzeiro do sul, indica, nas palavras do ministro Celso Amorim, o sentido da Cúpula: a reaproximação entre as duas regiões (MRE, 2005a). De acordo com Farah (2008:199), o logotipo criado para o evento reflete o objetivo de integração proposto pela reunião. Sobre um fundo verde, desenhou-se o globo terrestre, tendo, em um dos lados, uma lua crescente, que se refere aos países árabes e, do outro, a constelação do cruzeiro do sul, representando a América do Sul, conforme indica a figura 7.

Figura 7: Logotipo da Cúpula ASPA

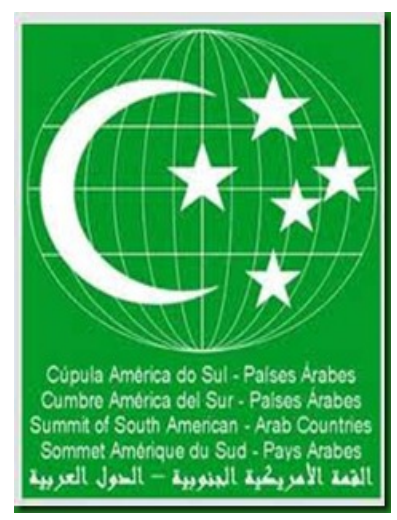

Fonte: $<$ http://www.tvcanall.com.br/tvcanal1/fotos/aspa_thumb.jpg $>$. Acesso em 23 de agosto de 2014. 
Para além do principal objetivo de criar contrapoder diante do status quo do sistema internacional contemporâneo, nota-se tentativa da diplomacia brasileira e da Presidência da República do Brasil de inculcar discurso em prol da reforma da governança global, durante todas as Cúpulas ASPA. Ensaiou-se, no entanto, diversificar os objetivos e o sentido do fórum multilateral, para obter maior ressonância de seus interlocutores. Entre os principais objetivos da Cúpula ASPA elencados pelos formuladores de política externa brasileira, destacam-se 9899100101 : cooperação técnica entre as duas regiões; diálogo político birregional; desenvolvimento de ligações aéreas e marítimas; aproximação de países distantes, culturas distintas e percepções diferentes do mundo; implantação de nova geografia econômica e comercial internacional; fortalecimento de espaço político que contribua para a construção de um mundo de paz, democracia e justiça social; aumento da capacidade dos povos e dos governantes de olhar-se diretamente.

O deslumbramento e a alta expectativa em relação aos resultados da Cúpula ASPA ficam claros no discurso de encerramento do Presidente Lula, durante a Cúpula América do Sul - Países Árabes, realizada em Brasília, no dia 11 de maio de 2005:

\begin{abstract}
Para mim, esta Cúpula tem o sabor da construção de um alicerce, um alicerce qualquer que dará sustentação a uma casa sólida, um alicerce muito forte para dar sustentação a um monumento de relações internacionais que acabamos de concluir com a aprovação da Declaração de Brasília (MRE, 2005b: 152).
\end{abstract}

De acordo com análise de Carvalho Pinto (2013:103), ficou explícito que a Declaração de Brasília consistiu, basicamente, de uma "reafirmação de intenções de cooperação em diversos campos, como o econômico, o cultural, e o tecnológico, conjugado com uma preponderância extraordinária de assuntos de política árabe”. Ele acrescenta que a Declaração de Doha, resultado da segunda edição da Cúpula ASPA, em 2009, "não divergiu muito do leque temático patente na Declaração de Brasília",

\footnotetext{
${ }^{98}$ Nota à imprensa. Preparação da Cúpula dos Países Árabes e da América do Sul. Brasília, 21 de marco de 2005.

${ }^{99}$ Discurso do ministro das Relações Exteriores, embaixador Celso Amorim, na abertura da Reunião de Chanceleres da América do Sul e dos Países Árabes em Brasília, no dia 9 de maio de 2005.

${ }^{100}$ Discurso do Presidente da República, Luiz Inácio Lula da Silva, na sessão de abertura da Cúpula ASPA, em Brasília, no dia 10 de maio de 2005.

${ }^{101}$ Discurso do Presidente da República, Luiz Inácio Lula da Silva, no encerramento da Cúpula América do Sul - Países Árabes, em Brasília, no dia 11 de maio de 2005.
} 
tornando evidente a "preponderância de assuntos culturais no relacionamento interregional" (CARVALHO PINTO, 2013:104).

Mais uma vez, conforme ressaltado na sessão anterior, o "pré-papel” de ponte entre os povos e as culturas diferentes foi utilizado pela PEB para ganhar legitimidade de seus interlocutores e iniciar projeção de novos papéis do Brasil ao Oriente Médio. Em discurso de abertura da Cúpula ASPA, no dia 10 de maio de 2005, em Brasília, o Presidente Lula enfatizou o papel de ponte da PEB como forma de iniciar o diálogo com seus interlocutores árabes: "Hoje, estamos diante da oportunidade histórica de lançar os fundamentos de uma ponte de sólida cooperação entre a América do Sul e o Mundo Árabe" (MRE, 2005a). Da mesma forma, o item 3.2 da Declaração final da Cúpula ASPA, a Declaração de Brasília, reafirmou "a crescente importância da cultura como ponte de integração entre os povos e como atividade econômica que impulsiona o desenvolvimento e a cooperação mútua" (MRE, 2005a).

Consequentemente, após a projeção do "pré-papel” de ponte entre os povos, tanto o Presidente Lula quanto o chanceler Celso Amorim aproveitaram a ocasião de seus discursos durante a Cúpula América do Sul-Países Árabes (ASPA), para expressar o posicionamento de mediação brasileira no que diz respeito à Questão palestina e, paralelamente, para abrir espaço ao projeto brasileiro de incitar a reforma da governança global e do Conselho de Segurança das Nações Unidas (MRE, 2005b; 2008a; 2009a). No que diz respeito à Questão palestina, a PEB expressou-se, durante diversas reuniões da Cúpula ASPA, por meio de três posicionamentos principais: defesa da criação do Estado palestino; necessidade de manutenção do Estado de Israel; plena implantação do Mapa do Caminho ${ }^{102} 103104$.

A Questão palestina, estimada pelo Partido dos Trabalhadores (PT) desde a sua fundação, em 1980, foi tratada pela PEB por meio da defesa, tanto pelo Presidente Lula quanto pelo seu chanceler, da criação de um Estado palestino independente, com base nas fronteiras de 1967, e da necessidade da realização dos direitos nacionais legítimos do povo palestino. Segundo os formuladores da PEB do governo Lula, a questão da Palestina é central para o Oriente Médio, pois, enquanto não se resolver isso, nenhum dos problemas será resolvido (MRE, 2008a: 29; 2005b; 2008a; 2009a).

\footnotetext{
${ }^{102}$ Declaração de Brasília, assinada em 11 de maio de 2005.

${ }^{103}$ Reunião do ministro das Relações Exteriores, embaixador Celso Amorim, por ocasião da Reunião de Ministros das Relações Exteriores da Cúpula América do Sul - Países Árabes. Buenos Aires, Argentina, 20 de fevereiro de 2008.

${ }^{104}$ Discurso do Presidente da República, Luiz Inácio Lula da Silva, na sessão de abertura da II Cúpula América do Sul - Países Árabes em Doha, no Catar, em 31 de março de 2009.
} 
Quanto a Israel, apesar de o governo do Presidente Lula defender sua coexistência pacífica ao lado do Estado palestino, a PEB, à época, também se manifestou pela retirada de Israel de todos os territórios árabes ocupados para as fronteiras de 4 de junho de 1967 e pelo desmantelamento dos assentamentos judaicos, inclusive os de Jerusalém Oriental. De acordo com Carvalho Pinto (2013:105), a fala do Presidente Lula durante a II Cúpula ASPA enfatizou a "politização temática mais precisa, ao frisar os deveres internacionais que se colocam a Israel em relação aos palestinos e a proposta de participação dos países em desenvolvimento nas negociações do conflito israelo- árabes".

Em discurso durante o encerramento da Cúpula América do Sul - Países Árabes (ASPA), em 11 de maio de 2005, o Presidente Lula relembrou a seus interlocutores - tanto internos quanto externos - o quanto a defesa da criação de um Estado palestino é tema importante para ele e para o Partido dos Trabalhadores:

Eu nasci na política brasileira defendendo o Estado palestino, mas também nunca neguei a necessidade do Estado de Israel, e penso que o ser humano é muito inteligente para aprender que a paz é a única coisa que pode permitir a construção de um mundo harmonioso, democrático e socialmente justo (MRE, 2005b: 151).

Conforme se defende na hipótese central desta pesquisa, o Governo brasileiro, por meio de seus principais formuladores de política externa, aproveitou os papéis secundários projetados para o Oriente Médio, como o de criação de contrapoder por meio de novos arranjos político-diplomáticos, como a Cúpula ASPA, para projetar sobre seus interlocutores (internos e externos) um dos principais objetivos da política externa brasileira, ou seja, a reforma da governança global e, em especial, do Conselho de Segurança das Nações Unidas. Por conseguinte, percebe-se que, em reiteradas ocasiões relacionadas à Cúpula $\mathrm{ASPA}^{105}$, os principais agentes da $\mathrm{PEB}$, como o Presidente Lula e o chanceler Celso Amorim, reivindicaram mudanças nas Nações Unidas e, em particular, a democratização do Conselho de Segurança das

\footnotetext{
${ }^{105}$ Durante quatro ocasiões principais relacionadas à Cúpula ASPA, o governo brasileiro posicionou-se explicitamente em relação à necessidade de reforma da governança global: 1) entrevista coletiva com o Presidente Lula após o encerramento da I Cúpula ASPA, em maio de 2005, em Brasília; 2) discurso do Presidente Lula na sessão de abertura da I Cúpula América do Sul - Países Árabes, em maio de 2005, em Brasília; 3) discurso do ministro das Relações Exteriores, embaixador Celso Amorim, por ocasião da Reunião de Ministros das Relações Exteriores da Cúpula América do Sul - Países Árabes, em fevereiro de 2008, em Buenos Aires; 4) discurso do Presidente da República, Luiz Inácio Lula da Silva, na sessão de abertura da II Cúpula América do Sul - Países Árabes, em março de 2009, em Doha.
} 
Nações Unidas (CSNU). A propósito, o Brasil, como coordenador da Cúpula ASPA, conseguiu incluir, no item 2 da Declaração de Brasília ${ }^{106}$, assinada em 11 de maio de 2005 por todos os membros, a necessidade da reforma das Nações Unidas:

"2.7 Lembram que, para cumprir seu papel, as Nações Unidas necessitam de uma reforma ampla e abrangente, particularmente no tocante à Assembleia Geral e ao Conselho de Segurança, que assegure maior eficiência, democracia, transparência e representatividade desses órgãos de acordo com suas respectivas naturezas e funções e com seus objetivos originais".

Quando se lançou pergunta acerca do posicionamento brasileiro em relação ao terrorismo e à reforma da governança global em entrevista coletiva logo após o encerramento da Cúpula ASPA, em Brasília, em 11 de maio de 2005, os jornalistas obtiveram a seguinte resposta do Presidente Luiz Inácio Lula da Silva:

\begin{abstract}
Muitas vezes, não se cumpre o que é aprovado nas Nações Unidas. Gostaria que fosse cumprido tudo o que se aprova nas Nações Unidas. Por isso é que queremos ampliar o CSNU, democratizá-lo, fazer que haja representação dos continentes: continente africano, continente latino-americano, países importantes do mundo que possam participar, o mundo árabe, para que tenhamos, dentro do CSNU, não a geografia política e territorial que tínhamos em 1945, mas que tenhamos a geografia política e territorial que temos em 2005. É isso que queremos.
\end{abstract}

Quanto às realizações da I e da II Cúpula América do Sul-Países Árabes realizadas, respectivamente, em Brasília (maio de 2005) e em Doha (março de 2009), destacam-se seis desdobramentos decorrentes da aproximação birregional: aumento em 170\% do comércio entre a América do Sul e os Países Árabes (que saltou de US\$ 11 milhões, em 2004, para US\$ 30 bilhões, em 2008); estabelecimento de novas câmaras de comércio entre as duas regiões; criação da Biblioteca ASPA ${ }^{107}$, em São Paulo e em Argel, e de iniciativas culturais subsequentes ${ }^{108}$; novas conexões aéreas

\footnotetext{
${ }^{106}$ Item 2 da Declaração de Brasília, relativo ao fortalecimento da cooperação birregional, das relações multilaterais, da paz e da segurança.

${ }^{107}$ Os ministros da Cultura árabes e sul-americanos, reunidos em Argel, em fevereiro de 2006, aprovaram a criação da Biblioteca ASPA, cuja primeira tarefa editorial foi concretizada em outubro de 2007 (MRE, 2007b).

${ }^{108}$ Em 24 de outubro de 2007, foi lançado o primeiro volume da Biblioteca América do Sul - Países Árabes (ASPA), intitulado Deleite do estrangeiro em tudo o que é espantoso e maravilhoso, do imã Adurrahmánal-Baghdádi. Trata-se do único registro conhecido da percepção árabe e mulçumana sobre a paisagem tropical e a sociedade multiétnica e multiconfessional que se formava no Brasil. Em outubro de 2006, foi lançada mostra do cinema sul-americano contemporâneo em Túnis e exposição intitulada "Uma história de dois rios: o Amazonas e o Nilo" no Museu Emílio Goeldi, em Belém (PA).
} 
entre a América do Sul e os países árabes; desenvolvimento de projetos de cooperação técnica no combate à desertificação em zonas áridas; criação do Instituto de Pesquisa sobre a América do Sul no Marrocos.

Percebe-se, dessa maneira, que a diplomacia brasileira utilizou-se da Cúpula América do Sul - Países Árabes não apenas para cumprir o objetivo de aproximação político e comercial entre as duas regiões, mas também para criar contrapoder econômico e político diante das potências tradicionais. A Cúpula ASPA segue as estratégias brasileiras de concertação política ampla em fóruns e organizações internacionais. Objetivou-se, dessa maneira, conforme os discursos do Presidente Lula e do chanceler Celso Amorim explicitam, buscar aliados e formar alianças para o projeto maior da PEB de reforma da governança global, em especial, do Conselho de Segurança das Nações Unidas, posicionando-se em sentido oposto ao status quo vigente, com relação ao sistema multilateral de segurança internacional.

\subsubsection{Os acordos comerciais do MERCOSUL com Países do Oriente Médio}

Os acordos de cooperação econômica e de livre comércio assinados entre o MERCOSUL e os países do Oriente Médio ao longo dos oito anos de mandato do governo Lula também podem ser analisados, sob o ponto de vista econômico, como tentativa por parte da PEB de criar alternativas ao status quo existente ou, pelo menos, de projetar-se internacionalmente como país que objetiva isso mediante os arranjos de livre comércio previamente estabelecidos no sistema internacional. Conforme posição oficial do Itamaraty, pode ser considerado como uma das estratégias da PEB do governo Lula o empenho do MERCOSUL em ampliar entendimentos com parceiros no Oriente Médio (MRE, 2007b). Consequentemente, entre 2005 e 2010, foram assinados acordos de cooperação econômica e iniciadas discussões acerca da criação de áreas de livre comércio com Israel, Palestina, Egito, Conselho de Cooperação do Golfo (CCG), Jordânia, Síria e Marrocos.

O Acordo de Livre Comércio entre o MERCOSUL e Israel, assinado em 18 de dezembro de 2007, em Montevidéu, foi o primeiro com um parceiro extrarregional, finalizando processo de negociação iniciado em 2005. De acordo com nota oficial emitida pelo Ministério das Relações Exteriores por ocasião da visita ao Brasil do da revista $F I K R$, de estudos árabes e sul-americanos. 
ministro dos Negócios Estrangeiros de Israel, Avigdor Lieberman, em 21 de julho de 2009, verificou-se, após a assinatura do acordo de livre comércio entre Israel e MERCOSUL, crescente intercâmbio entre os dois países, atingindo a cifra recorde de US\$ 1,6 bilhão em 2008, além da multiplicação de visitas de autoridades de ambos os lados (FUNAG, 2010; MRE, 2007b). Segundo Mailhold (2010), em artigo publicado pelo Real Instituto Elcano, a conclusão de acordo de livre comércio com Israel gerou inquietações da contraparte Palestina, criando iniciativas para futuro acordo de livre comércio entre o Brasil e a Autoridade Nacional Palestina:

El nuevo TLC fue criticado por Mahmud Abbas, quien enfatizó en sus conversaciones con Lula que el acuerdo no excluye los productos de colonizadores israelíes en Palestina. El ministro brasileño de Desarrollo, Industria y Comercio Exterior, Miguel Jorge, anunció la disposición y el compromiso de los Estados miembros del Mercosur por iniciar próximamente las negociaciones de un TLC con la Autoridad Nacional Palestina.

Com relação à Palestina, o Acordo-Quadro de Comércio e Cooperação Econômica entre o MERCOSUL e a Organização para a Libertação da Palestina (em nome da Autoridade Nacional Palestina) foi assinado em Foz do Iguaçu, no dia 16 de dezembro de 2010, por ocasião da XL Reunião do Conselho do Mercado Comum (CMC) do MERCOSUL (MRE, 2010b). O referido Acordo-Quadro tem como objetivo o fortalecimento das relações entre as partes contratantes, por meio da promoção e da expansão do comércio e do estabelecimento das condições e dos mecanismos necessários para a negociação de uma área de livre comércio (ALC).

Em dezembro de 2011, durante a gestão da Presidente Dilma Rousseff, foi assinado o Acordo de Livre-Comércio entre o MERCOSUL e a Autoridade Nacional Palestina. Em nota oficial ${ }^{109}$, o governo brasileiro, por meio do MERCOSUL, aproveitou a ocasião para expressar seu posicionamento em relação à causa palestina:

\footnotetext{
O Acordo é expressão do apoio dos Estados partes do MERCOSUL ao estabelecimento de um Estado palestino independente e democrático, geograficamente coeso e economicamente viável - que possa viver de forma pacífica e harmoniosa com seus vizinhos.
}

Como resultado da quinta rodada de negociações entre o MERCOSUL e o Egito, ocorreu, em San Juan, reunião que finalizou as negociações para o acordo de

\footnotetext{
${ }^{109}$ Nota n. 497 - Acordo de Livre Comércio MERCOSUL - Palestina.
} 
livre comércio. O instrumento firmado entre o MERCOSUL e o Egito, em agosto de 2010, na Argentina, é o segundo do MERCOSUL com parceiro extrarregional (depois de Israel). O referido acordo finaliza processo de negociação iniciado em julho de 2004, com a assinatura do Acordo-Quadro entre a República Árabe do Egito e o MERCOSUL, em Puerto Iguazú, Argentina, por ocasião das XXVI Reunião do Conselho do Mercado Comum (MRE, 2010b).

Conforme dados do Ministério do Desenvolvimento, Indústria e Comércio Exterior (MDIC), tal acordo destina-se à abertura ao mercado bilateral de bens, além de conter cláusula evolutiva sobre a possibilidade de entendimentos, no futuro, para acesso a serviços e investimentos. A conclusão do referido acordo ${ }^{110}$ passou a promover novas oportunidades comerciais para exportação de produtos brasileiros para o Egito, como, por exemplo, frango, café solúvel, papel e automóveis. Dos 25 principais produtos exportados pelo Brasil para o Egito, no ano passado, 22 terão tarifa zero no final do período de desgravação (MRE, 2010b).

As negociações para a criação de futura área de livre comércio entre o MERCOSUL ${ }^{111}$ e o Conselho de Cooperação do Golfo ${ }^{112}$ foram iniciadas com a assinatura de Acordo-Quadro de Cooperação Econômica (ACE), durante a I Cúpula dos Países da América do Sul e dos Países Árabes (ASPA), realizada em Brasília, em maio de 2005. O referido Acordo-Quadro teve como objetivos, para além da implantação de área de livre comércio: a criação de oportunidades concretas de negócios para os membros de ambos os blocos; o incremento das relações entre os países árabes e os sul-americanos, promovendo cooperação nas áreas econômica, comercial, técnica e de investimento; o aprofundamento da dimensão econômica de ambos os blocos. Percebeu-se o aumento dos fluxos comerciais e a expansão dos investimentos e das parcerias no setor privado, entre as duas regiões, desde a assinatura do ACE, em 2005 (FUNAG, 2007; FUNAG, 2010; MRE, 2005a; MRE, 2005b; MRE, 2007a; MRE, 2009a).

Até o fim do governo Lula, não havia ocorrido a conclusão do Acordo de Livre-Comércio entre o MERCOSUL e o CCG. Durante a II Cúpula ASPA, em Doha, em março de 2009, houve apenas emissão de Comunicado Conjunto MERCOSUL-

\footnotetext{
${ }^{110} \mathrm{O}$ acordo de livre comércio entre o MERCOSUL e o Egito é composto por cinco capítulos: I. Disposições gerais; II. Regras de origem; III. Salvaguardas preferenciais; IV. Solução de controvérsias; V. Disposições finais.

${ }^{111}$ Integram o MERCOSUL os seguintes países: Argentina, Brasil, Paraguai e Uruguai.

${ }^{112}$ O Conselho de Cooperação do Golfo (CGG) é integrado por Arábia Saudita, Barein, Catar, Emirados Árabes Unidos, Kuait e Omã.
} 
CCG e de Declaração MERCOSUL-CCG, reafirmando o compromisso assumido pelas partes com base no Acordo de Cooperação Econômica em criar Área de Livre Comércio entre o MERCOSUL e o CCG. Na ocasião, mantiveram encontro o chanceler paraguaio no exercício da Presidência pro tempore do MERCOSUL, Alejandro Hamed Franco, e o chanceler de Omã, Yousef bin Alawi bin Abdulla, no exercício da presidência do Conselho de Ministros do CCG (MRE, 2009a).

Entre os principais instrumentos previstos para o futuro acordo de livre comércio entre o MERCOSUL e o CCG destacam-se: preâmbulo e disposições gerais; capítulo acerca do comércio de bens (que estabelece parâmetros para profunda liberalização comercial em um período de 8 anos); capítulo sobre serviços (que prevê a liberalização de mercados de serviços além dos níveis já acordados pelas partes na OMC); capítulos sobre investimentos (que estabelecem marco para o tratamento nacional e a liberalização de acesso a mercados); disposições institucionais finais. Esse conjunto de instrumentos será complementado por anexos sobre solução de controvérsias e salvaguardas e pelos cronogramas de compromissos específicos sobre serviços e investimentos ${ }^{113}$ (MRE, 2007a).

Com relação à Jordânia, foi assinado, durante a última Cúpula do MERCOSUL, em Tucumán, em $1^{\circ}$ de julho de 2008, Acordo-Quadro de Livre Comércio entre o MERCOSUL e a Jordânia, que visa à criação de zona de livre comércio com o objetivo de fortalecer os laços econômico-comerciais bilaterais (FUNAG, 2010). Em comunicado conjunto emitido por ocasião da visita ao Brasil do Rei da Jordânia, Abdullah II, em 23 de outubro de 2008, os dirigentes brasileiro e jordaniano reafirmaram seu compromisso com a conclusão das negociações de um acordo de livre comércio entre o MERCOSUL e a Jordânia o mais rapidamente possível $^{114}$ (MRE, 2008b). Segundo relata Mailhold (2010), com a Jordânia, foram firmados 11 acordos na área científica, tecnológica e de turismo, elaborados para oferecer o marco adequado para lançar joint ventures no futuro, especialmente em matéria de energias renováveis.

\footnotetext{
${ }^{113}$ Declaração MERCOSUL - Conselho de Cooperação dos Estados Árabes do Golfo (CCG) - 18 de janeiro de 2007, emitida pelos ministros das Relações Exteriores dos Estados partes do MERCOSUL e pelo subsecretário-geral do Conselho de Cooperação dos Estados Árabes do Golfo, reunidos no Rio de Janeiro, por ocasião do encontro do Conselho do Mercado Comum do MERCOSUL.

${ }^{114} \mathrm{Na}$ mesma ocasião, os dirigentes do Brasil e da Jordânia saudaram a realização de Fórum Comercial Brasil-Jordânia em São Paulo e a assinatura de acordos entre a Câmara de Comércio Árabe-Brasileira e a Câmara de Comércio da Jordânia e entre esta e a Confederação Nacional da Indústria (CNI).
} 
Com relação à República Árabe da Síria, o Acordo-Quadro para o estabelecimento de área de livre comércio entre o MERCOSUL e a República Árabe da Síria foi assinado (da mesma forma que o acordo com a OLP) em Foz do Iguaçu, no dia 16 de dezembro de 2010, por ocasião da XL Reunião do Conselho do Mercado Comum (CMC) do MERCOSUL (MRE, 2010b). O estabelecimento de AcordoQuadro sobre comércio entre o MERCOSUL e o Reino do Marrocos, por sua vez, ocorreu em novembro de 2004, em Brasília. Ambos os acordos possuem como objetivo o fortalecimento das relações inter-regionais por meio da promoção e da expansão do comércio e da criação de condições e de mecanismos necessários à negociação de Área de Livre Comércio (ALC).

ABIS (2009:22) ressalta, em artigo publicado em revista científica francesa, a importância da I Cúpula ASPA para o início das negociações comerciais entre o MERCOSUL e alguns países do Oriente Médio:

\begin{abstract}
Le sommet de Brasilia avait marqué le début d'une coopération interrégionale et reflétait la tendance actuelle à la polarisation des échanges au sein des grands groupes régionaux. Aussi, la réaffirmation au sommet de Doha de la nécessité de promouvoir les initiatives ayant pour but la conclusion d'accords commerciaux entre les Etats d'Amérique latine et les pays arabes, semble confirmer cette tendance. En 2008, des négociations commerciales entre le Mercosul et l'Égypte, la Jordanie et le Maroc ont été engagées et récemment, la reprise des échanges entre le Mercosul et le Conseil de Coopération du Golfe (CCG) avaient pour but travailler à la création d'une zone de libre-échange (2009:22).
\end{abstract}

Defende-se nesta pesquisa que os acordos de comércio, cooperação econômica e livre comércio assinados pelo governo brasileiro com seis países árabes e Israel ao longo dos dois mandatos do governo Lula ${ }^{115}$ fazem parte da estratégia maior de cooperação sul-sul, portanto, da ideia promovida pela diplomacia brasileira por meio dos formuladores da PEB de criação de arranjos alternativos, diante do status quo prevalecente no sistema internacional. Dessa forma, argumenta-se que os sete acordos do MERCOSUL com a região do Oriente Médio são um dos desdobramentos do papel projetado pelo governo brasileiro de criador de novos arranjos econômicos ou,

\footnotetext{
${ }^{115}$ São esses os referidos acordos: 1) Acordo de Livre Comércio entre o MERCOSUL e o Estado de Israel; 2) Acordo de Livre Comércio entre o MERCOSUL e a República Árabe do Egito; 3) AcordoQuadro de Comércio e Cooperação econômica entre o MERCOSUL e a OLP, em nome da Autoridade Nacional Palestina; 4) Acordo-Quadro entre o MERCOSUL e o Reino Hashemita da Jordânia; 5) Acordo-Quadro para o Estabelecimento de uma Área de Livre Comércio entre o MERCOSUL e a República Árabe da Síria; 6) Acordo sobre Comércio entre o MERCOSUL e o Reino do Marrocos; 7) Acordo-Quadro de Cooperação econômica entre os Estados partes do MERCOSUL e os Estados membros do Conselho de Cooperação dos Estados Árabes do Golfo.
} 
de forma mais ousada, conforme conceitua Holsti (1970), de agente antistatus quo ao sistema imperialista vigente, no caso em questão, no que diz respeito às relações econômicas internacionais.

A tabela 5, abaixo, objetiva enumerar os principais acordos comerciais entre o bloco econômico do MERCOSUL e os países do Oriente Médio, assinados ao longo dos oito anos do governo Lula (2003-2010) ${ }^{116}$.

Tabela 5: Acordos comerciais entre o MERCOSUL e os Países do Oriente Médio, assinados ao longo do governo Lula (2003-2010)

\begin{tabular}{|c|c|c|c|}
\hline País & Título do Acordo & $\begin{array}{l}\text { Data da assinatura } \\
\text { ou da entrada em } \\
\text { vigor }\end{array}$ & Situação \\
\hline Israel & $\begin{array}{l}\text { Acordo-Quadro sobre comércio entre o } \\
\text { MERCOSUL e o Estado de Israel - Dec. n. 22/05. } \\
\text { Acordo de livre comércio entre o MERCOSUL e } \\
\text { o Estado de Israel - Dec. n. 50/07 (18.12.2007) }\end{array}$ & $\begin{array}{l}3 / 4 / 2010 \text { (entrada em } \\
\text { vigor) }\end{array}$ & Vigente \\
\hline Palestina & $\begin{array}{l}\text { Acordo-Quadro de Comércio e Cooperação } \\
\text { Econômica entre o MERCOSUL e a Organização } \\
\text { para a Libertação da Palestina, em nome da } \\
\text { Autoridade Nacional Palestina. } \\
\text { Acordo de Livre Comércio MERCOSUL- Estado } \\
\text { da Palestina. }\end{array}$ & $\begin{array}{l}\text { 20/12/2011 } \\
\text { (assinado em } \\
\text { Montevidéu) }\end{array}$ & $\begin{array}{l}\text { Em } \\
\text { tramitação, } \\
\text { sem vigência }\end{array}$ \\
\hline Egito & $\begin{array}{l}\text { Acordo-Quadro entre o MERCOSUL e a } \\
\text { República Árabe do Egito }\end{array}$ & - & $\begin{array}{l}\text { Em } \\
\text { tramitação }\end{array}$ \\
\hline Egito & $\begin{array}{l}\text { Acordo de Livre-Comércio entre o MERCOSUL e } \\
\text { a República Árabe do Egito }\end{array}$ & $\begin{array}{l}2 / 8 / 2014 \\
\text { (assinado em San } \\
\text { Juan, Argentina) } \\
\end{array}$ & Sem vigência \\
\hline $\begin{array}{l}\text { Conselho de } \\
\text { Cooperação do } \\
\text { Golfo (CCG) }\end{array}$ & $\begin{array}{l}\text { Acordo-Quadro de Cooperação Econômica entre } \\
\text { os Estados-partes do MERCOSUL e os membros } \\
\text { do Conselho de Cooperação dos Estados Árabes } \\
\text { do Golfo (CCG) }\end{array}$ & $\begin{array}{l}\text { 10/5/2005 (assinado } \\
\text { em Brasília) }\end{array}$ & Sem vigência \\
\hline Jordânia & $\begin{array}{l}\text { Acordo-Quadro entre o MERCOSUL e o Reino } \\
\text { Hashemita da Jordânia (Dec. n. 28/08) }\end{array}$ & $\begin{array}{l}\text { 30/6/2008 } \\
\text { (assinado em São } \\
\text { Miguel de Tucumán) }\end{array}$ & $\begin{array}{l}\text { Em } \\
\text { tramitação }\end{array}$ \\
\hline Síria & $\begin{array}{l}\text { Acordo-Quadro para o estabelecimento de área de } \\
\text { livre comércio entre o MERCOSUL e a República } \\
\text { Árabe da Síria }\end{array}$ & $\begin{array}{l}16 / 12 / 2010 \\
\text { (assinado em Foz do } \\
\text { Iguaçu) }\end{array}$ & $\begin{array}{l}\text { Em } \\
\text { tramitação }\end{array}$ \\
\hline Marrocos & $\begin{array}{l}\text { Acordo-Quadro sobre Comércio entre o } \\
\text { MERCOSUL e o Reino do Marrocos }\end{array}$ & $\begin{array}{l}\text { 26/11/2004 (assinado } \\
\text { em Brasília) }\end{array}$ & Sem vigência \\
\hline
\end{tabular}

${ }^{116}$ Elaboração com base em notas oficiais emitidas pelo Ministério das Relações Exteriores. 


\subsection{Conclusão}

O presente capítulo teve por objetivo apresentar, discutir e analisar, por meio da Role Theory, os papéis classificados como secundários e concebidos pelos formuladores e pelos executores da PEB para o Oriente Médio durante o Governo Lula (2003-2010). São eles: ponte entre povos e regiões, defensor da paz e dos direitos humanos, agente promotor de assistência humanitária internacional e criador de novos arranjos políticos, diplomáticos e econômicos alternativos ao status quo.

Optou-se por apresentar, de maneira breve, a Role Theory e seus principais desdobramentos conceituais sobre o papel nacional: concepção, percepção e desempenho. O foco nas projeções das concepções de papéis nacionais, feito pela PEB em relação ao Oriente Médio, foi analisado por metodologia de decodificação de discursos de indivíduos-chaves para a construção e a identificação das concepções dos papéis nacionais.

No terceiro capítulo, objetiva-se analisar o papel mais importante projetado pelo Brasil em relação ao Oriente Médio: o de mediador de conflitos (ou construtor de consensos). Os esforços da política externa brasileira em desempenhar esse papel serão apresentados por meio de dois estudos de caso principais: a questão palestina e a questão nuclear iraniana. Intenciona-se argumentar, da mesma maneira que foi feito ao longo do segundo capítulo, como o papel de mediador foi, durante o conflito Israel-Palestina e a questão nuclear iraniana, instrumentalizado pelos formuladores e pelos executores da PEB do governo Lula para a consecução de um dos principais objetivos da PEB: o de agente promotor da reforma da governança global, em especial, das instâncias de segurança multilaterais, como o CSNU. 


\section{CAPÍTULO 3: Os esforços de mediação da política externa brasileira nos casos} da questão palestina e da questão nuclear iraniana

O presente capítulo tem por objetivo demonstrar padrões de comportamento da PEB em suas duas principais tentativas de mediação no Oriente Médio, durante o governo Lula: na questão palestina e na questão nuclear iraniana. A apresentação do Brasil como mediador de conflitos e construtor de consensos foi o que mais chamou a atenção das contrapartes brasileiras e pode ser classificada como a concepção de papel nacional primário e mais importante da PEB para o Oriente Médio. Além disso, expõem-se evidências da principal hipótese da pesquisa, a de que todos os papéis projetados pela PEB do governo Lula em relação ao Oriente Médio objetivaram, na verdade, a consecução e a difusão da principal finalidade: a reforma da governança global e, em especial, do Conselho de Segurança das Nações Unidas.

\subsection{O Brasil como mediador de conflitos e construtor de consensos}

De acordo com Holsti (1970:233-309), o papel de mediador é exercido por aqueles países cujos governos percebem-se capazes, ou responsáveis, por preencher e tomar medidas especiais, para reconciliar conflitos entre outros Estados ou grupos de Estados. Os países que aderem a essa concepção atribuem a si uma tarefa contínua de ajudar os adversários a reconciliar suas diferenças conforme demonstra discurso do chanceler sueco Torsten Nilsson em 1966:

It is obvious that our foreign policy should support realistic attempts to obtain a continued détente. Our position as a neutral state makes this particularly natural while at the same time giving us special responsibilities ${ }^{117}$ for fruitful contacts with different groups of states.

As principais fontes do papel nacional de mediador, de acordo com a Role Theory proposta por Holsti (1970:233-309), encontram-se, dessa maneira, em quatro características principais dos países que se autoconcebem como mediadores

\footnotetext{
${ }^{117}$ Grifo nosso.
} 
internacionais: papel nacional tradicional; composição cultural e étnica diversificada do Estado em questão; tradição de não envolvimento em conflitos; localização geográfica estratégica do país.

\subsection{A mediação brasileira na questão palestina durante os governos Lula}

Os governos anteriores à gestão Lula não se autoproclamavam capazes de fornecer algum tipo de contribuição decisiva aos conflitos entre árabes e israelenses. A histórica e tradicional relação entre o PT e a luta pelos direitos dos povos palestinos foi decisiva para que a atitude da PEB com relação à questão palestina mudasse a partir de 2003. Em artigo recente, Élodie Brun (2011) cita declaração do Presidente Lula acerca de seu posicionamento (e de seu partido), com relação à questão palestina: "I was born in Brazilian politics defending Palestinian state, but never did I deny then ecessity of the state of Israel either" (BRUN, 2011; SANTANA, 2005).

Em consonância com as características elencadas por Holsti (1970) dos países que se autoproclamam mediadores de conflitos, o chanceler Amorim listou três elementos principais que justificam o atual interesse do Brasil na questão palestina: enorme comunidade árabe e importante comunidade judaica em território brasileiro (composição cultural e étnica do Estado brasileiro); o fato de alguns cidadãos brasileiros encontrarem-se, atualmente, ameaçados pelo conflito; a percepção da PEB de que, o que ocorre no Oriente Médio, embora envolva essencialmente árabes, palestinos e israelenses, na realidade, interessa a toda a humanidade, porque ali está a sorte da paz no mundo (MRE, 2009b:61).

\subsubsection{Concepção do papel nacional de mediador}

Ao longo dos oito anos da gestão Lula, os formuladores brasileiros de política externa expressaram, em seus discursos e em suas conversas com governantes dos países do Oriente Médio, durante visitas oficiais ${ }^{118}$, o desejo de contribuir, ativamente, para a mediação do conflito entre palestinos e israelenses e a plena

\footnotetext{
${ }^{118}$ Discurso do ministro Celso Amorim no Seminário sobre Paz e Reconciliação em Oslo (2007); palavras do ministro Celso Amorim por ocasião de encontro com representantes da comunidade libanesa no Clube Monte Líbano, em São Paulo (2006); declaração à imprensa do Presidente da República, Luiz Inácio Lula da Silva, por ocasião da visita do Presidente de Israel, Shimon Peres (2009); declaração à imprensa do Presidente da República, Luiz Inácio Lula da Silva, por ocasião da visita do Presidente da Autoridade Nacional Palestina (ANP), Mahmoud Abbas, a Salvador (2009).
} 
capacidade e legitimidade do país para tal fim. O Brasil, por meio do Presidente Lula e do chanceler Amorim, anunciou, publicamente, sua disposição e seu desejo em colaborar com o processo de construção da paz entre as principais partes do conflito, ou seja, entre Israel e a Autoridade Nacional Palestina (ANP).

Em declaração à imprensa, durante visita do Presidente de Israel, Shimon Peres, a Brasília, em 11 de novembro de 2009, o Presidente Lula assim ofereceu ajuda brasileira a sua contraparte israelense na mediação da questão palestina: "Israelenses e palestinos não devem temer os sacrifícios da paz. Uns como os outros podem contar com o Brasil para a construção de uma paz cujas repercussões positivas transcenderão as fronteiras do Oriente Médio (MRE, 2009b)".

Apenas nove dias após a visita do mandatário israelense, em 20 de novembro de 2009, o Presidente Lula recebeu a visita do Presidente da Autoridade Nacional Palestina (ANP), Mahmoud Abbas, e assim expressou sua intenção em contribuir, ativamente, para a mediação do conflito árabe-judaico:

A paz e a estabilidade no Oriente Médio interessam à Humanidade. E tudo o que interessa à Humanidade não nos é alheio. O Brasil quer ajudar a construí-la. Estou convencido de que o processo de paz se beneficiará da contribuição de outros países, além dos que tradicionalmente estiverem envolvidos (MRE, 2009b).

Para ambas as partes envolvidas no principal conflito da região do Oriente Médio - e para os países membros do Quarteto - o Brasil ofereceu seus préstimos como mediador legítimo e confiável, capaz de atuar de forma neutra e oferecer novas alternativas às tradicionais iniciativas das potências envolvidas na região. A projeção da concepção do papel nacional de mediador de conflitos, nesse caso, é bastante clara. Por outro lado, a recepção de seus principais interlocutores, ou seja, a aceitação ou a rejeição dos outros atores do sistema internacional quanto à atuação pelo Brasil como mediador do conflito árabe-israelense não é um fato tão óbvio de ser afirmado, necessitando análise profunda da reação dos principais atores do sistema internacional diante da autoproclamação da PEB como mediador confiável na região. 


\subsubsection{Percepção por outros atores do papel do Brasil como mediador}

A maneira como os outros países, em especial, os principais interlocutores da questão palestina (Israel e a ANP) consideram o papel do Brasil no conflito não é tão óbvia quanto nos fazem crer os discursos oficiais dos representantes brasileiros. Em razão do recorte temático do trabalho, não foi realizada pesquisa aprofundada acerca do posicionamento dos interlocutores do Brasil que legitimariam ou não o papel do Brasil como mediador da questão palestina. No entanto, é pouco provável que a afirmativa de Amorim, segundo a qual "O Brasil é um interlocutor respeitado e valorizado pelos dois lados, um parceiro confiável e que não desperta animosidade de um lado ou de outro", seja aceita de forma inconteste pelos principais mediadores da questão palestina e pelas duas partes em jogo.

Ao analisar os discursos e as entrevistas do Presidente Lula e do chanceler Amorim, notou-se que, por, pelo menos, quatro vezes distintas, o chanceler da Autoridade Nacional Palestina e o Presidente Abbas solicitaram ao Brasil maior envolvimento nas negociações de paz entre árabes e israelenses. De acordo com relato do chanceler Amorim, em palestra proferida a alunos do IRBr, durante a primeira visita oficial ao Oriente Médio, em dezembro de 2003, o Presidente Lula foi procurado pelo ministro das Relações Exteriores da ANP, Nabil Shaat, que sugeriu maior aproximação do Brasil na mediação dos conflitos na região. Na ocasião, o chanceler palestino fez duas propostas ao governo brasileiro: a criação de uma missão brasileira em Ramallah e o estabelecimento do cargo, na chancelaria brasileira, de um enviado especial para o Oriente Médio ${ }^{119}$ (AMORIM: 2011, 186-190).

De forma paralela, em palestra realizada pelo ministro Celso Amorim em 4 de agosto de 2010, acerca do novo papel do Brasil no mundo, foi ressaltado o crescente interesse pela contraparte palestina à participação do Brasil nas várias dimensões do conflito árabe-israelense, como, por exemplo, no diálogo intrapalestino, no diálogo entre Palestina e Israel e nas questões que envolvem Israel e Síria. Observa-se, no entanto, que, apesar de o ministro Amorim enfatizar que o Brasil é um interlocutor solicitado tanto por árabes quanto por israelenses, os discursos, as visitas e as notas oficiais mostram que o lado palestino é privilegiado em relação ao israelense,

\footnotetext{
$119 \mathrm{O}$ ministro Celso Amorim, à época, escolheu o embaixador Affonso Celso de Ouro-Preto para ser o enviado especial brasileiro ao Oriente Médio. O embaixador Ouro-Preto havia sido chefe de gabinete do ministro Amorim durante o governo de Itamar Franco.
} 
especialmente, tratando-se de posicionamentos políticos a favor da ANP e da criação oficial de um Estado palestino.

No universo das 52 notas oficiais analisadas emitidas pelo Itamaraty acerca da questão palestina e do conflito árabe-israelense, entre 2003 e 2010, por exemplo, percebe-se que a maior parte delas se manifesta a favor das causas palestinas. Assim, 4 delas condenam ataques realizados por forças palestinas ao território de Israel, 11 são de condenação a ações militares de Israel, 4 são neutras, conclamando o trabalho conjunto para a paz, e 12 manifestam, claramente, o apoio à criação de um Estado palestino livre, independente e soberano, sendo a última delas, emitida em 3 de dezembro de 2010, a nota de reconhecimento do Estado palestino nas fronteiras de 1967 (MRE, 2003b; MRE, 2004b; MRE, 2005a; MRE, 2005b; MRE, 2006a; MRE, 2006b; MRE, 2007a; MRE, 2007b; MRE, 2008a; MRE, 2008b; MRE, 2009a; MRE, 2009b; MRE, 2010a; MRE, 2010b).

As notas oficiais que condenam ações palestinas, além de menos numerosas, empregam vocabulário leve e condenam, por exemplo, o lançamento de foguetes a partir de Gaza, contra alvos civis israelenses e contra a cidade judaica de Haifa. Por outro lado, as notas que condenam Israel tendem a utilizar termos verbais incisivos, como deplorar, lamentar, conclamar, e expressam posição do Estado brasileiro contra, por exemplo, o impedimento por Israel da liberdade de movimento da população palestina, as ofensivas militares em Gaza, a retirada de palestinos de suas casas em Jerusalém Oriental e a construção ou a autorização de novos assentamentos e casas nos territórios ocupados. Foram expedidas, ademais, 12 notas que manifestam, explicitamente, a posição favorável do governo do Presidente Lula à criação de um Estado palestino independente, soberano e livre, além da nota de reconhecimento oficial do Estado palestino nas fronteiras de 1967, transmitida ao público no último mês do último ano de mandato do Presidente Lula, em dezembro de 2010.

\subsubsection{Principais linhas de posicionamento da gestão Lula com relação à questão palestina}

Por meio da análise de discursos, entrevistas e artigos dos formuladores de política externa brasileiros à época da gestão Lula (em especial o Presidente e seu chanceler, Celso Amorim), foi possível delimitar os principais posicionamentos da PEB acerca de cinco grandes linhas da questão palestina, tais como: criação de um 
Estado palestino; manutenção do Estado de Israel; hierarquia da questão palestina na política internacional contemporânea; respeito às normas do direito internacional; comportamento de novos atores acerca da questão palestina.

No que diz respeito à criação do Estado palestino, o Brasil defendeu em seus discursos e posicionamentos oficiais que a paz duradoura na região do Oriente Médio depende, diretamente, da criação e da manutenção de um Estado palestino independente, coeso, seguro, democrático e economicamente viável, coexistindo em paz, com Israel. A PEB do governo Lula enfatizou, ademais, que a normalização das relações dos países árabes com Israel só ocorrerá na medida em que haja um Estado palestino viável, coeso e sem restrições. Como contrabalanço, em raros discursos, a diplomacia brasileira ressaltou o direito à existência e à segurança de Israel nas fronteiras reconhecidas internacionalmente.

Quanto à hierarquia da questão palestina na política internacional contemporânea, a PEB de Lula enfatizou por meio do chanceler Amorim e do Presidente Lula que os conflitos no Oriente Médio apenas seriam resolvidos quando a questão palestina fosse solucionada. Segundo Celso Amorim, por exemplo, em discurso por ocasião da Reunião de Chanceleres da Cúpula ASPA, em fevereiro de 2008, em Buenos Aires, a "solução profunda para os problemas do Oriente Médio está na situação do povo palestino" (FUNAG, 2010). O respeito ao Direito Internacional Humanitário e à implantação das resoluções do CSNU acerca do tema também foi amplamente defendido pela diplomacia brasileira, além da sugestão de que novos atores, junto às tradicionais potências, envolvam-se na questão palestina (MRE, 2005a; 2005b; 2006b; 2007b; 2008a; 2009a; 2009b).

No que diz respeito às ações concretas realizadas pela diplomacia brasileira com relação à Palestina durante os anos da gestão de Luiz Inácio Lula da Silva, cabem destacar: a criação de escritório de representação do Brasil em Ramallah, as frequentes visitas de autoridades brasileiras aos territórios ocupados e a criação do cargo de enviado especial do Brasil para o Oriente Médio. Algumas realizações, conforme destaca o chanceler Amorim (2011), foram iniciativas do governo brasileiro, como o aumento exponencial do número de visitas oficiais à região; outras medidas, como a abertura de representação brasileira na Palestina e a nomeação de encarregado da chancelaria brasileira para administrar assuntos específicos de Oriente Médio, foram sugestões tanto do Presidente Abbas da ANP quanto do chanceler palestino à época, Nabil Shaat. 


\subsubsection{Os grandes temas da questão palestina e o Brasil}

Em razão da multiplicidade e da complexidade temática que envolve a questão palestina, foi possível, ao longo da análise das fontes primárias e secundárias, enumerar sete temas específicos diante dos quais a PEB se posicionou em suas tentativas de mediação, ao longo dos oito anos do governo Lula. São eles: proposição e delimitação das fronteiras entre os dois Estados; papel de Israel; questão dos assentamentos; conflito intrapalestino; povo palestino; papel da Síria; papel da Conferência de Annapolis.

No que diz respeito à proposição de dois Estados e ao estabelecimento das fronteiras entre Israel e Palestina, percebeu-se que, por diversas ocasiões, como durante a visita do Presidente da Autoridade Nacional Palestina (ANP), Mahmoud Abbas, ao Brasil, em 2009, e durante a Conferência Internacional em apoio à economia palestina para a reconstrução de Gaza, também em 2009, no Egito, tanto o Presidente Lula quanto o chanceler Amorim deixaram nítida a posição do Brasil perante a proposição dos dois Estados e de suas fronteiras. De acordo com a PEB de Lula, seria essencial a solução de dois Estados verdadeiros, na qual a Palestina fosse estabelecida de forma não setorizada e convivesse lado a lado, com Israel (MRE, 2009a; MRE, 2009b; AMORIM, 2011; FARAH, 2008).

A diplomacia brasileira enfatizou que os obstáculos à solução da coexistência dos dois Estados, como a expansão dos assentamentos por Israel e o uso frequente da força militar, devessem ser suspensos. Segundo Amorim (2011:201):

\footnotetext{
Não há como, em uma questão desse tipo, ter uma solução puramente militar. Ela simplesmente não existe. Não há como aniquilar totalmente o Hamas (sem discutir se seria desejável). Porque esses movimentos vicejam, e até prosperam, quando há uma situação de repressão. Pode haver, em determinado momento, uma redução substancial do poderio militar do Hamas, mas ele vai aos poucos ressurgindo, como já ressurgiu outras vezes. E não me parece que Israel possa viver cercado de países hostis.
}

No que diz respeito a Israel, suas ações, deveres e direitos em relação à questão palestina, tanto o Presidente Lula quanto o chanceler Amorim apontaram a posição brasileira. Segundo Amorim, em discurso durante Conferência Internacional em apoio à economia palestina para a reconstrução de Gaza, em março de 2009, 
estaria nas mãos de Israel garantir que a ANP pudesse cumprir as promessas do processo de paz. O Presidente Lula, por sua vez, ressaltou, durante a II Cúpula ASPA ocorrida em Doha, em março de 2009, a importância do engajamento firme do novo governo de Israel no processo de paz, com base nos acordos anteriormente alcançados e no plano árabe de paz. Em notas oficiais, o governo brasileiro lamentou as mortes e a destruição causadas por operações das forças de defesa de Israel em Gaza e em territórios palestinos, mas defendeu que Israel tem o direito de viver em paz e segurança nas fronteiras internacionais reconhecidas (MRE, 2005b; 2003b; 2009a).

Mailhold (2010), no entanto, indica que a relação entre o governo do Presidente Lula e Israel não foi tão equilibrada quanto os discursos fazem crer:

\begin{abstract}
Un primer indicador de lo complicado que es la situación en la cual se está metiendo Brasil fue el boicot que declaró el canciller israelí Avigdor Lieberman al no asistir a las citas con Lula debido a su reticencia a visitar la tumba del padre del sionismo - Theodor Herzl - mientras que en Palestina depositó una ofrenda floral en la tumba de Yassir Arafat e inauguro la cercana calle Brasil en Ramallah.
\end{abstract}

A temática dos assentamentos judaicos, conforme explica Amorim (2011:423), é a questão que mais ocupa a imaginação e o espírito dos palestinos e a que mais fere sua sensibilidade. De acordo com o chanceler brasileiro, ao promover e ao tolerar a contínua expansão dos assentamentos, Israel alimenta as correntes mais radicais na Palestina. Em discurso no Parlamento israelense, durante visita oficial a Israel, o Presidente Lula não deixou de reafirmar a necessidade de manter o congelamento dos assentamentos israelenses, posição reiterada em outras ocasiões pela PEB $^{120}$, como, por exemplo, durante a visita do Presidente da Autoridade Nacional Palestina (ANP), Mahmoud Abbas, a Salvador e durante entrevista concedida pelo chanceler Amorim ao Jornal Al Ahram, em abril de 2005.

Entre 2003 e 2010, o Itamaraty expediu cinco notas oficiais acerca da posição do Estado brasileiro em relação aos assentamentos israelenses. A primeira delas, em julho de 2005, versava sobre a violência em Israel e nos territórios palestinos e exortava a desativação de assentamentos judeus na Palestina, além de sua entrega à administração da ANP (MRE, 2005b). Na segunda nota, emitida em agosto de 2009, o Brasil deplorava a retirada de cerca de 50 palestinos de suas casas em Jerusalém

\footnotetext{
${ }^{120}$ Durante esses momentos, o Presidente Lula e o chanceler Amorim reafirmaram a condenação do Brasil, a expansão dos assentamentos judaicos e a necessidade de congelamento das construções.
} 
Oriental, as quais foram posteriormente ocupadas por cidadãos israelenses; na mesma nota oficial, o Brasil instava as autoridades de Israel a reverter sua decisão, dado seu efeito prejudicial à criação de condições mínimas para a paz na região.

$\mathrm{Na}$ terceira nota, expedida em novembro de 2009, o governo brasileiro posiciona-se de maneira mais rígida, acerca da construção de 900 novas casas no assentamento de Gilo, localizado em Jerusalém Oriental. De acordo com o posicionamento do Itamaraty, a expansão desse assentamento representou "duro golpe nos esforços internacionais que visam à retomada do processo de paz na região e constituiu obstáculo à consecução do objetivo do futuro Estado palestino, geograficamente coeso e economicamente viável. Dessa forma, o Brasil pediu que Israel revisse a decisão anunciada, de modo a ampliar as decisões políticas para que israelenses e palestinos voltassem à mesa de negociações (MRE, 2009b).

As duas últimas notas oficiais acerca dos assentamentos, de março e setembro de 2010, versavam, respectivamente, sobre o pesar do Brasil acerca da autorização israelense para a construção de 1600 novas unidades habitacionais em Jerusalém Oriental e 112 moradias na Cisjordânia e sobre o fim da moratória de expansão de assentamentos em territórios palestinos ocupados. De acordo com a última nota, o Brasil dizia estar preocupado com atos no terreno palestino, como a retomada das construções por parte dos colonos israelenses, o que prejudicaria o andamento das negociações diretas entre Israel e a ANP (MRE, 2010b).

No que diz respeito ao conflito intrapalestino, o Brasil do governo Lula manteve posição segundo a qual não haveria paz alguma na região do Oriente Médio enquanto não fosse possível a reconciliação entre os palestinos. O Presidente Lula, por exemplo, durante a II Cúpula ASPA, afirmou que o Brasil aplaudia os esforços para a reconciliação interpalestina (AMORIM, 2011:204). De forma paralela, em 2007, por duas ocasiões diferentes (Acordo de princípios para a constituição de Governo da União Nacional na ANP e Situação nos territórios palestinos), o Brasil manifestou-se em prol da reconciliação entre os grupos políticos palestinos. $\mathrm{Na}$ primeira ocasião, o Estado brasileiro disse esperar que o Acordo contribuísse para a diminuição das tensões e das disputas internas entre as principais forças políticas palestinas e, em segundo momento de manifestação oficial, a PEB, diante da dissolução do governo de União Nacional e da decretação do estado de emergência nos territórios palestinos, reiterou seu apelo em prol da imediata cessação de 
hostilidades e do pronto reinício do diálogo entre as facções palestinas como condição essencial para a retomada do processo de paz na região (MRE, 2007a).

O povo palestino também foi lembrado - e defendido - pela diplomacia brasileira. Assim, de forma paralela à campanha de reconciliação entre as diferentes facções políticas palestinas, o Brasil ressaltou, ao longo dos oito anos de governo Lula, direitos humanos básicos da população civil palestina, tais como: liberdade de circulação, dignidade humana, autodeterminação e direito de residência. Em declaração à imprensa por ocasião da visita do Presidente da Autoridade Nacional Palestina (ANP), Mahmoud Abbas, ao Brasil, o Presidente Lula afirmou (MRE, 2009b): "Os palestinos devem ter maior liberdade de circulação nos Territórios Palestinos Ocupados. A situação humanitária na Faixa de Gaza é insustentável. A dignidade humana não pode continuar a ser ignorada (grifo nosso)".

Em ocasiões diferentes ${ }^{121}$, ademais, o Brasil expediu notas oficiais em defesa da população palestina. Em junho de 2006, por exemplo, por ocasião de grave situação humanitária nos territórios palestinos em razão de ataques da força militar israelense nos territórios palestinos ocupados, o governo brasileiro exortou que cessassem as medidas restritivas à liberdade de movimento e ao direito de residência da população palestina radicada nos territórios ocupados, além de deplorar os sofrimentos impostos à população civil palestina (MRE, 2006a). As notas de 2007, por seu turno, dizem respeito ao apoio do governo brasileiro ao direito do povo palestino à sua autodeterminação, à constituição de um Estado independente e à proteção da população civil durante os conflitos (MRE, 2007a; 2007b).

Nos pontos específicos da Questão palestina sobre os quais a diplomacia brasileira se posicionou entre 2003 e 2010, cabe notar o papel da Síria e o da Conferência de Annapolis. Quanto à Síria, segundo Amorim (2011), é um país de muita influência tanto no Líbano quanto na questão palestina, e, segundo o chanceler, ignorar a Síria "significa deixar de trabalhar efetivamente, para obter a paz"122". A participação do Brasil na Conferência de Annapolis, em novembro de 2007, por seu turno, pode ser considerada um dos fatores que mais contribuíram para a elevação da autoestima dos negociadores e dos diplomatas brasileiros, difundindo, em profusão, a

\footnotetext{
${ }^{121}$ Notas expedidas nos dias 7 de junho de 2006, 28 de junho de 2006, 13 de março de 2007, 13 de junho de 2007 e 15 de junho de 2007.

${ }_{122}$ Declaração dada em aula a alunos do Instituto Rio Branco (IRBr) acerca das relações Brasil Oriente Médio, no dia 7 de outubro de 2010.
} 
concepção de papel nacional do Brasil como mediador importante e legítimo na questão palestina.

Em seu livro de memórias, Amorim (2011:145) conta, com orgulho, o convite feito pelo governo dos EUA ao Brasil e "alguns poucos outros países doadores tradicionais e partes no conflito" para participar da Conferência de Annapolis, nos EUA, acerca da paz no Oriente Médio e da situação palestina. De acordo com o Presidente Lula, a reunião de Annapolis significou o primeiro passo na direção de um debate transparente e democrático acerca dos rumos da paz na região do Oriente Médio (MRE, 2009a). O objetivo de Annapolis, segundo o chanceler Amorim, foi o de retomar o processo de paz no Oriente Médio, com ênfase no conflito israelopalestino (MRE, 2007b).

A especialidade e a diferenciação da reunião de Annapolis encontram-se, segundo Amorim (2011:191), no formato do agrupamento que permitiu a grande número de países, representantes de várias regiões, dar legitimidade internacional ao processo de paz em perspectiva pragmática de busca de soluções, para além da reafirmação de princípios. De acordo com Amorim, Annapolis era especialmente importante para Israel, pois oferecia aos judeus oportunidade diferenciada de entendimento com a comunidade internacional ${ }^{123}$. Durante a reunião, a posição do Brasil não fugiu ao padrão esperado; os representantes brasileiros defenderam a constituição de um Estado palestino independente e economicamente viável em convivência pacífica com Israel (MRE; 2007a, 2007b).

\subsubsection{Sugestões da PEB para o conflito Israel - Palestina}

A PEB do governo Lula não se manteve neutra ou silenciosa acerca de possíveis soluções e sugestões para o desenlace do conflito Israel - Palestina. Ao longo dos oito anos da gestão Lula, três foram as principais ações defendidas pela diplomacia brasileira com o objetivo de solucionar a questão: envolvimento de novos atores no processo de paz; criação de grupo de amigos para a paz no Oriente Médio; realização de grande conferência de paz com novos atores participantes, além dos tradicionais. Com o objetivo de sugerir novas ideias, além de conduzir a bom termo o

\footnotetext{
${ }^{123}$ De acordo com Amorim (2011:191), Israel queixava-se muito das votações na ONU, em especial na AGNU, onde prevaleciam maiorias automáticas, representadas pelo grupo dos não alinhados, o grupo africano, o grupo dos países árabes, etc.
} 
processo de paz no Oriente Médio, atingir a paz sustentável na região e assegurar que o caminho do diálogo na questão palestina seja seguido, os representantes brasileiros propuseram o envolvimento abrangente de todos os atores relevantes da comunidade internacional no processo de paz da região (MRE, 2007b; 2009a; 2009b).

Em apresentação durante seminário internacional de mídia sobre a paz no Oriente Médio, em julho de 2009, o ministro Celso Amorim expressou, de forma bastante clara, a proposta brasileira de inclusão de novos atores no processo de paz:

Se há algo que nós sentimos de limitado no processo de paz, no Mapa do Caminho, no que tem sido discutido até hoje, não são tanto as propostas, mas o fato de que os interlocutores são sempre os mesmos. Falta um arejamento nessas discussões, e é isso que nós interpretamos que pode ser um dos papéis que o Brasil, não só o Brasil, mas também outros países em desenvolvimento podem fazer para contribuir para a paz (MRE, 2009b).

De acordo com a análise do ministro Amorim (2011:146), o convite feito pelos EUA para que o Brasil participasse da Conferência de Annapolis pode ser considerado prova do reconhecimento de uma proposta do governo brasileiro de que países em desenvolvimento, como os três do IBAS convidados, que não são parte da região do Oriente Médio nem do mundo islâmico e não têm, tradicionalmente, relação estreita com a questão palestina - como o Brasil, a Índia e a África do Sul - podem contribuir para temas tratados sob perspectiva antiga e sem grandes resultados. A tabela 6, abaixo, indica o quanto a PEB repetiu, reiteradas vezes e em locais variados, a proposta de inclusão de novos atores no processo de paz no Oriente Médio ${ }^{124}$.

Tabela 6: Proposta da PEB para inclusão de novos atores no processo de paz no Oriente Médio, em especial, na questão palestina

\begin{tabular}{|c|c|c|c|}
\hline $\begin{array}{l}\text { Agente da } \\
\text { PEB }\end{array}$ & Ocasião, local e data & Proposta & Objetivo \\
\hline $\begin{array}{l}\text { Presidente } \\
\text { Lula }\end{array}$ & $\begin{array}{l}\text { Carta do Presidente } \\
\text { Lula ao Presidente da } \\
\text { ANP (Mahmoud } \\
\text { Abbas). Ramallah, } 21 \\
\text { de agosto de 2007. }\end{array}$ & $\begin{array}{l}\text { - Envolvimento abrangente e } \\
\text { determinado da comunidade } \\
\text { internacional. } \\
\text {-Engajamento de todos os atores } \\
\text { relevantes ao processo de paz. }\end{array}$ & $\begin{array}{l}\text { - Conduzir, a bom termo, o } \\
\text { processo de paz no Oriente } \\
\text { Médio. } \\
\text { - Atingir a paz sustentável. }\end{array}$ \\
\hline
\end{tabular}

${ }^{124}$ Elaboração com base em notas oficiais à imprensa emitidas pelo Ministério das Relações Exteriores. 


\begin{tabular}{|l|l|l|l|}
\hline $\begin{array}{l}\text { Ministro Celso } \\
\text { Amorim }\end{array}$ & $\begin{array}{l}\text { Seminário sobre Paz e } \\
\text { Reconciliação. Oslo, } \\
\text { 14 de setembro de } \\
2007 .\end{array}$ & $\begin{array}{l}\text { - A comunidade internacional } \\
\text { tem a obrigação de trabalhar } \\
\text { com as partes envolvidas no } \\
\text { processo de paz. } \\
\text { - Precisamos envolver mais } \\
\text { países no processo. }\end{array}$ & $\begin{array}{l}\text { - Assegurar que o caminho } \\
\text { do diálogo, não o da } \\
\text { confrontação, seja seguido. } \\
\text { - Renovar ideias e } \\
\text { propostas. }\end{array}$ \\
\hline $\begin{array}{l}\text { Ministro Celso } \\
\text { Amorim }\end{array}$ & $\begin{array}{l}\text { Conferência em apoio } \\
\text { à economia Palestina } \\
\text { para a reconstrução de } \\
\text { Gaza. Sharm El-Sheik, } \\
\text { Egito, 2 de março de } \\
\text { 2009. }\end{array}$ & $\begin{array}{l}\text { - Todos os atores relevantes na } \\
\text { região devem ter uma chance de } \\
\text { participar no processo de paz do } \\
\text { Oriente Médio. }\end{array}$ & $\begin{array}{l}\text { - Agir construtivamente no } \\
\text { processo de paz. }\end{array}$ \\
\hline $\begin{array}{l}\text { Presidente } \\
\text { Lula }\end{array}$ & $\begin{array}{l}\text { Abertura da II Cúpula } \\
\text { ASPA. Doha, 31 de } \\
\text { março de 2009. }\end{array}$ & $\begin{array}{l}\text { - Participação de todos os atores } \\
\text { relevantes ao processo de paz do } \\
\text { Oriente Médio. }\end{array}$ & $\begin{array}{l}\text { - Buscar soluções para os } \\
\text { graves problemas do } \\
\text { Oriente Médio. }\end{array}$ \\
\hline $\begin{array}{l}\text { Ministro Celso } \\
\text { Amorim }\end{array}$ & $\begin{array}{l}\text { Seminário } \\
\text { Internacional de Mídia } \\
\text { sobre a paz no Oriente } \\
\text { Médio. Rio de Janeiro, } \\
\text { 27 de julho de 2009. }\end{array}$ & $\begin{array}{l}\text { - Necessidade de inclusão de } \\
\text { novos interlocutores ao processo } \\
\text { de paz no Oriente Médio. }\end{array}$ & $\begin{array}{l}\text { - O Brasil e outros países } \\
\text { em desenvolvimento } \\
\text { podem contribuir para a } \\
\text { paz. } \\
\text { - Arejar as discussões. }\end{array}$ \\
\hline
\end{tabular}

Uma das principais sugestões da PEB para os conflitos do Oriente Médio e em prol da manutenção de seu objetivo de reforma da governança global foi a de realização de ampla conferência de paz. Durante discurso na AGNU, em setembro de 2006, nesse sentido, o Presidente Lula defendeu a convocação de conferência de paz sobre o Oriente Médio, sob os auspícios da ONU, com participação abrangente que incluísse não apenas as grandes potências, mas também os países da região afetados e os em desenvolvimento, como o Brasil. Tanto o Presidente Lula quanto o chanceler Celso Amorim repetiram essa proposta em diversas ocasiões, como no encontro com representantes da comunidade libanesa, no Clube Monte Líbano, em setembro de 2006, em seminário sobre a paz e a reconciliação, em Oslo, em setembro de 2007, e durante a II Cúpula América do Sul - Países Árabes, em março de 2009 (MRE, 2006b; 2007b; 2009a).

Outra iniciativa da PEB quanto à resolução do conflito Israel - Palestina foi a constituição - e a genuína disposição brasileira em participar - de um Grupo de Amigos para a paz no Oriente Médio. De acordo com a visão brasileira, o referido Grupo deveria ser coordenado pelo secretário-geral da ONU e ser composto por países com perfil de construção de consensos, credibilidade internacional e boas relações com todas as partes. Segundo Celso Amorim, em discurso no Seminário 
sobre Paz e Reconciliação, em setembro de 2007, em Oslo, "talvez um pouco de ar fresco seja benéfico ao processo de paz". Nota-se, nessa proposta brasileira, uma vez mais, forte intenção em reformar a governança global e, mais especificamente, a forma como a metodologia do processo de paz é conduzida (MRE, 2007b).

Ao longo dos oito anos do governo Lula, o Brasil propôs outras soluções, modos de negociação e princípios norteadores com o objetivo de alcançar a paz e a solução para a questão palestina. Segundo posição defendida pela diplomacia brasileira, a negociação deve ser feita por meio do diálogo com todas as partes envolvidas no conflito, de modo a evitar atitudes negativas, como a exclusão e o isolamento. De acordo com a PEB, o diálogo deve ser pautado por concessões políticas de todos os lados, de forma que se alcance solução negociada para a questão palestina - ponto central dos conflitos no Oriente Médio (MRE, 2009b; 2006b; 2008a). Segundo Élodie Brun (2011), "the main ideia remains the same: bring all parties together to negotiate around a common table, from the more moderate to the more radical".

O princípio norteador "Terra por Paz" foi defendido pelo ministro Celso Amorim em discurso durante a Conferência de Annapolis, em 27 de novembro de 2007. De acordo com o chanceler brasileiro:

Terra por paz continua a ser um princípio norteador para
uma solução negociada duradoura. Isso deve levar a um
Estado palestino soberano, democrático, coeso e
economicamente viável em um horizonte de tempo digno
de crédito. A paz deve incluir também medidas eficientes
para proteger e defender Israel contra atos de violência e
para permitir a manutenção de relações pacíficas e
produtivas com Estados Árabes.

O Presidente Lula, o chanceler Amorim e representantes brasileiros em instâncias multilaterais internacionais defenderam que a paz na região somente será alcançada por meio de cinco passos principais: a criação de um Estado palestino próspero, coeso e independente, vivendo pacificamente, lado a lado, com Israel; o respeito - principalmente por Israel - ao Direito Internacional Humanitário e ao Direito Internacional dos Direitos Humanos; a obediência às resoluções e às decisões do CSNU; o reconhecimento por todos os líderes mundiais da necessidade de criação de um Estado palestino e da condenação da ocupação de territórios palestinos por Israel; a inclusão de novos atores nas negociações internacionais sobre a questão 
palestina $^{125}$. A tabela 7 evidencia o posicionamento oficial do Governo brasileiro no período da gestão do Presidente Lula, por ordem cronológica, em relação ao conflito Israel - Palestina ${ }^{126}$.

Tabela 7: Posicionamento oficial do governo brasileiro por ordem cronológica em relação ao conflito Israel-Palestina (2003-2010)

\begin{tabular}{|c|c|c|}
\hline Data & Motivo & Posição do Brasil \\
\hline 4.10 .2003 & $\begin{array}{l}\text { Condenação do atentado } \\
\text { ocorrido em Haifa, norte } \\
\text { de Israel (MRE, 2003b) }\end{array}$ & $\begin{array}{l}\text { - } \quad \text { Retorno à mesa de negociação em prol da paz e } \\
\text { da segurança do povo palestino e israelense. } \\
\text { - } \quad \text { Cessação da hostilidade. } \\
\text { - Condenação de iniciativas que não favoreçam a } \\
\text { confiança, como a construção do muro nos } \\
\text { territórios palestinos e o anúncio de novos } \\
\text { assentamentos nos territórios ocupados. }\end{array}$ \\
\hline 23.10 .2003 & $\begin{array}{l}\text { Acompanhamento pelo } \\
\text { Governo brasileiro da } \\
\text { ininterrupta onda de } \\
\text { violência no } \\
\text { relacionamento israelo- } \\
\text { palestino (MRE, 2003b) }\end{array}$ & $\begin{array}{l}\text { - O Brasil conclama os membros do Quarteto }{ }^{127}, \\
\text { patrocinadores do Mapa da Paz, a intervir } \\
\text { firmemente para que Israel e Palestina cessem as } \\
\text { hostilidades recíprocas. } \\
\text { - O Governo brasileiro lamenta as mortes, os } \\
\text { feridos e a destruição causada por operações das } \\
\text { Forças de Defesa de Israel na cidade de Gaza. }\end{array}$ \\
\hline 2.12 .2003 & $\begin{array}{l}\text { Comunicado à imprensa } \\
\text { sobre iniciativa para a paz } \\
\text { no Oriente Médio (MRE, } \\
\text { 2003b) }\end{array}$ & $\begin{array}{l}\text { Nutrimos a esperança de que Israel e Palestina } \\
\text { trabalhem conjuntamente, em favor de uma } \\
\text { solução pacífica do conflito, por meio de } \\
\text { concessões recíprocas. Somente pela via da } \\
\text { negociação e do diálogo, poderá alcançar-se a } \\
\text { paz duradoura. }\end{array}$ \\
\hline 10.8 .2004 & $\begin{array}{l}\text { Encontro do chefe do } \\
\text { Escritório de } \\
\text { Representação do Brasil } \\
\text { junto à Autoridade } \\
\text { Nacional Palestina com o } \\
\text { chanceler palestino. } \\
\text { Ramalá, } 10 \text { de agosto de } \\
2004 \text { (MRE, 2004b) }\end{array}$ & $\begin{array}{l}\text { - A Autoridade Nacional Palestina manifesta } \\
\text { satisfação pelo gesto do Brasil em abrir o } \\
\text { Escritório de Representação em Ramalá. } \\
\text { - A autoridade palestina enfatizou a importância } \\
\text { do papel reservado ao Brasil na temática do } \\
\text { Oriente Médio e, em particular, na solução do } \\
\text { conflito israelo-palestino (NATIONAL ROLE } \\
\text { PERCEPTION). }\end{array}$ \\
\hline
\end{tabular}

\footnotetext{
${ }^{125}$ Segundo Farah $(2008 ; 185-187)$, a paz entre israelenses e palestinos não pode ser patrocinada pelos EUA, apenas.

${ }^{126}$ Elaboração com base em notas oficiais emitidas pela Assessoria de Imprensa do Ministério das Relações Exteriores.

${ }^{127}$ Grupo formado por Estados Unidos, Rússia, ONU e União Europeia.
} 


\begin{tabular}{|c|c|c|}
\hline 12.11 .2004 & $\begin{array}{l}\text { Participação do Brasil na } \\
\text { cerimônia fúnebre do } \\
\text { Presidente Yasser Arafat }\end{array}$ & $\begin{array}{l}\text { Certos de que as lideranças palestinas saberão } \\
\text { manter vivos os ideais de seu incansável } \\
\text { representante, o Governo brasileiro reafirma o } \\
\text { apoio à criação de um Estado palestino livre e } \\
\text { soberano e à construção de um futuro de paz e } \\
\text { prosperidade para o Oriente Médio. }\end{array}$ \\
\hline 9.6 .2005 & $\begin{array}{l}\text { Comunicado à imprensa } \\
\text { sobre a violência em Israel } \\
\text { e nos Territórios Palestinos } \\
\text { (MRE, 2005a) }\end{array}$ & $\begin{array}{l}\text { O Governo brasileiro exorta as partes em } \\
\text { conflito a cessar as hostilidades e manter-se fiéis } \\
\text { aos entendimentos logrados entre Israel e a } \\
\text { Autoridade Nacional Palestina, durante a } \\
\text { Conferência de Paz em Sharm-el-Sheikh, em } 8 \\
\text { de fevereiro de 2005, e aos parâmetros } \\
\text { estabelecidos no Mapa do Caminho para a Paz. }\end{array}$ \\
\hline 15.7 .2005 & $\begin{array}{l}\text { Violência em Israel e nos } \\
\text { territórios palestinos }\end{array}$ & $\begin{array}{l}\text { - } \text { Morre a cidadã brasileira e israelense Dana } \\
\text { Galkowicz, vítima de ataque de míssil. } \\
\text { - O Governo brasileiro exorta todas as partes } \\
\text { envolvidas a evitar quaisquer iniciativas que } \\
\text { possam comprometer os preparativos em curso } \\
\text { para a retirada das Forças de Defesa de Israel da } \\
\text { Faixa de Gaza, a desativação de assentamentos } \\
\text { judeus naquele território sua entrega à } \\
\text { administração da ANP prevista para o mês de } \\
\text { agosto seguinte. }\end{array}$ \\
\hline 17.8 .2005 & $\begin{array}{l}\text { Comunicado à imprensa } \\
\text { sobre a execução do plano } \\
\text { israelense de } \\
\text { desengajamento de Gaza } \\
\text { (MRE, 2005b) }\end{array}$ & $\begin{array}{l}\text { - O Governo brasileiro compartilha o anseio da } \\
\text { comunidade internacional para que a ANP possa } \\
\text { assumir, sem incidentes e em ambiente de paz, o } \\
\text { controle pleno sobre o território de Gaza, em } \\
\text { seguida à saída dos colonos. } \\
\text { - O Brasil entende que o Plano de } \\
\text { Desengajamento de Gaza representa iniciativa } \\
\text { capaz de contribuir, de forma significativa, para } \\
\text { fazer avançar o processo de paz no Oriente } \\
\text { Médio. } \\
\text { A posição da PEB e a de criação de um Estado } \\
\text { palestino soberano, economicamente viável e } \\
\text { geograficamente coeso que assegure o direito de } \\
\text { Israel à existência e à segurança nas fronteiras } \\
\text { internacionalmente reconhecidas. }\end{array}$ \\
\hline 27.10 .2005 & $\begin{array}{l}\text { Comunicado à imprensa } \\
\text { sobre a mensagem do } \\
\text { chanceler de Israel ao } \\
\text { ministro Celso Amorim } \\
\text { (MRE, 2005b) }\end{array}$ & $\begin{array}{l}\text { O ministro Celso Amorim reiterou ao chanceler } \\
\text { Shalom a posição brasileira de que, ao mesmo } \\
\text { tempo em que reconhece o direito palestino a } \\
\text { um Estado soberano, defende ter o Estado de } \\
\text { Israel o direito de viver em paz e segurança nas } \\
\text { fronteiras internacionalmente reconhecidas. }\end{array}$ \\
\hline
\end{tabular}

\footnotetext{
${ }^{128}$ Participou da cerimônia fúnebre do Presidente Yasser Arafat o então ministro de Estado e chefe da Casa Civil, José Dirceu, em comitiva integrada por parlamentares e diplomatas.
} 


\begin{tabular}{|c|c|c|}
\hline 18.11 .2005 & $\begin{array}{l}\text { Comunicado à imprensa } \\
\text { dos acordos sobre a Faixa } \\
\text { de Gaza (MRE, 2005b) }\end{array}$ & $\begin{array}{l}\text { O ministro Amorim registrou que os acordos } \\
\text { obtidos para o tratamento de questões de } \\
\text { fronteira, logística e infraestrutura constituem } \\
\text { decisivos avanços nas negociações de paz e na } \\
\text { implantação das diretrizes estabelecidas pelo } \\
\text { Mapa do Caminho para a Paz. }\end{array}$ \\
\hline 6.12 .2005 & $\begin{array}{l}\text { Comunicado à imprensa } \\
\text { sobre o atentado em } \\
\text { Netanya, Israel (MRE, } \\
2005 \text { b) }\end{array}$ & $\begin{array}{l}\text { O Governo brasileiro exorta os Governos de } \\
\text { Israel e da Autoridade Nacional Palestina (ANP) } \\
\text { a que prossigam nas negociações de paz, com } \\
\text { vistas à implantação das medidas contempladas } \\
\text { no Mapa do Caminho para a Paz. }\end{array}$ \\
\hline 13.12 .2005 & $\begin{array}{l}\text { Viagem do embaixador } \\
\text { extraordinário ao Oriente } \\
\text { Médio }\end{array}$ & $\begin{array}{l}\text { Disposição do Brasil de contribuir, de forma } \\
\text { ativa, em conjunto com outros países em } \\
\text { desenvolvimento de projeção externa, para os } \\
\text { esforços empreendidos pela comunidade } \\
\text { internacional, com vistas à retomada das } \\
\text { negociações de paz entre Israel e a ANP, em } \\
\text { conformidade com os parâmetros estabelecidos } \\
\text { pelo Mapa do Caminho para a Paz. } \\
\text { - Disposição transmitida ao primeiro-ministro } \\
\text { Ariel Sharon por ocasião da visita do ministro } \\
\text { Celso Amorim a Israel, em maio de } 2005 .\end{array}$ \\
\hline 15.3 .2006 & $\begin{array}{l}\text { Recrudescimento da } \\
\text { violência nos Territórios } \\
\text { Palestinos (MRE, 2006a) }\end{array}$ & $\begin{array}{l}\text { O Governo brasileiro conclama as partes a tomar } \\
\text { medidas que contribuam para sustar a espiral de } \\
\text { violência, inclusive a libertação de pessoas } \\
\text { sequestradas. }\end{array}$ \\
\hline 30.6 .2006 & $\begin{array}{l}\text { Novo Governo da } \\
\text { Autoridade Nacional } \\
\text { Palestina (ANP) }\end{array}$ & $\begin{array}{l}\text { O Governo brasileiro espera que o Governo } \\
\text { palestino possa lograr avanços efetivos no } \\
\text { processo de paz israelo-palestino, com a } \\
\text { retomada do diálogo entre as partes e os } \\
\text { esforços para a criação de Estado palestino, em } \\
\text { conformidade com os parâmetros fixados pelos } \\
\text { Acordos de Oslo e pelo Mapa do Caminho para } \\
\text { a Paz. }\end{array}$ \\
\hline 7.6 .2006 & $\begin{array}{l}\text { Situação nos Territórios } \\
\text { Palestinos (MRE, 2006a) }\end{array}$ & $\begin{array}{l}\text { - O Governo brasileiro apelou às partes para que } \\
\text { evitem o recurso à violência, em especial, contra } \\
\text { a população civil. } \\
\text { - O Brasil exortou que não sejam tomadas } \\
\text { medidas que restrinjam a liberdade de } \\
\text { movimento e o direito de residência da } \\
\text { população palestina radicada nos territórios } \\
\text { ocupados. }\end{array}$ \\
\hline
\end{tabular}




\begin{tabular}{|c|c|c|}
\hline 28.6 .2006 & $\begin{array}{l}\text { Situação nos Territórios } \\
\text { Palestinos Ocupados } \\
\text { (lançamento da operação } \\
\text { militar "Chuvas de } \\
\text { Verão", das Forças de } \\
\text { Defesa de Israel nos } \\
\text { Territórios Palestinos } \\
\text { ocupados) }\end{array}$ & $\begin{array}{l}\text { - } \begin{array}{l}\text { A embaixadora de Israel foi chamada ao } \\
\text { Itamaraty. }\end{array} \\
\text { - } \begin{array}{l}\text { O Governo brasileiro deplorou os sofrimentos } \\
\text { impostos à população civil palestina. }\end{array} \\
\text { - } \quad \begin{array}{l}\text { O Brasil exorta as partes em conflito a confiar } \\
\text { no papel que a comunidade internacional pode } \\
\text { desempenhar para a retomada do processo de } \\
\text { paz na região. }\end{array}\end{array}$ \\
\hline 28.11 .2006 & $\begin{array}{l}\text { Cessar-fogo na Faixa de } \\
\text { Gaza (MRE, 2006b) }\end{array}$ & $\begin{array}{l}\text { O Governo brasileiro considera que a decisão de } \\
\text { impor cessar-fogo em Gaza constitui passo } \\
\text { fundamental para restaurar a confiança e o } \\
\text { diálogo direto entre as partes e, assim, facilitar a } \\
\text { retomada das negociações de paz de acordo com } \\
\text { os critérios estabelecidos no Mapa do Caminho, } \\
\text { com vistas a uma solução justa, abrangente e } \\
\text { duradoura para o conflito. } \\
\text { O Brasil conclama as partes a respeitar o cessar- } \\
\text { fogo e a trabalhar com afinco para que seus } \\
\text { termos possam ser estendidos, com a brevidade } \\
\text { possível, ao território da Cisjordânia. }\end{array}$ \\
\hline 13.2 .2007 & $\begin{array}{l}\text { Acordo de princípios para } \\
\text { constituição de Governo } \\
\text { de União Nacional na } \\
\text { Autoridade Nacional } \\
\text { Palestina }\end{array}$ & $\begin{array}{l}\text { O Brasil espera que o Acordo contribua para a } \\
\text { diminuição de tensões e disputas internas entre } \\
\text { as principais forças políticas palestinas. } \\
\text { - O Brasil apoia a constituição do Estado } \\
\text { palestino independente, soberano, } \\
\text { geograficamente coeso e economicamente } \\
\text { viável em coexistência com Israel. }\end{array}$ \\
\hline 17.3 .2007 & $\begin{array}{l}\text { Constituição do Governo } \\
\text { de União Nacional na } \\
\text { Autoridade Nacional } \\
\text { Palestina. Aprovação pelo } \\
\text { Conselho Legislativo } \\
\text { Palestino (MRE, 2007a) }\end{array}$ & $\begin{array}{l}\text { - OO Governo brasileiro manifesta plena } \\
\text { disposição a apoiar iniciativas de cooperação } \\
\text { voltadas à melhoria das condições de vida nos } \\
\text { territórios palestinos e ao fortalecimento e à } \\
\text { consolidação das instituições locais. O Brasil } \\
\text { reitera seu apoio ao direito do povo palestino à } \\
\text { autodeterminação e à constituição do Estado } \\
\text { independente, soberano, geograficamente coeso } \\
\text { e economicamente viável em coexistência } \\
\text { pacífica com Israel". }\end{array}$ \\
\hline 17.5.2007 & $\begin{array}{l}\text { Situação na Faixa de Gaza: } \\
\text { lançamento reiterado de } \\
\text { foguetes a partir da Faixa } \\
\text { de Gaza contra alvos civis } \\
\text { israelenses, na cidade de } \\
\text { Sderot }\end{array}$ & $\begin{array}{l}\text { - O Governo conclama a imediata cessação desses } \\
\text { atos inaceitáveis e exorta todas as partes a } \\
\text { praticar a moderação, respeitar o direito } \\
\text { humanitário, proteger as populações civis e } \\
\text { evitar atos de represália. }\end{array}$ \\
\hline
\end{tabular}




\begin{tabular}{|c|c|c|}
\hline & & $\begin{array}{l}\text { O Brasil reitera seu apelo a fim de que sejam } \\
\text { criadas condições para viabilizar o cumprimento } \\
\text { do cessar-fogo em Gaza, acordado em novembro } \\
\text { de } 2006 \text {, e o restabelecimento do diálogo direto } \\
\text { entre as partes, de forma a não comprometer as } \\
\text { perspectivas de retomada do processo de paz na } \\
\text { região. }\end{array}$ \\
\hline 13.6 .2007 & $\begin{array}{l}\text { Agravamento da situação } \\
\text { nos territórios palestinos. } \\
\text { Acirramento dos } \\
\text { confrontos entre grupos } \\
\text { palestinos na Faixa de } \\
\text { Gaza e na Cisjordânia }\end{array}$ & $\begin{array}{l}\text { - O Brasil conclama todas as facções à imediata } \\
\text { cessação das hostilidades, à proteção das } \\
\text { populações civis, ao respeito ao direito } \\
\text { humanitário e ao estrito cumprimento do cessar- } \\
\text { fogo acordado em novembro de 2006, em Gaza. } \\
\text { - O Brasil reitera seu firme apoio aos esforços da } \\
\text { comunidade internacional no sentido de buscar a } \\
\text { consolidação política e institucional da ANP e a } \\
\text { manutenção do Governo da União Nacional. }\end{array}$ \\
\hline 15.6 .2007 & $\begin{array}{l}\text { Situação nos Territórios } \\
\text { Palestinos. Crescente } \\
\text { agravamento da situação } \\
\text { nos territórios palestinos e } \\
\text { recentes confrontos na } \\
\text { Faixa de Gaza. Dissolução } \\
\text { do governo de União } \\
\text { Nacional e decretação do } \\
\text { estado de emergência nos } \\
\text { territórios palestinos }\end{array}$ & $\begin{array}{l}\text { O Governo brasileiro reitera seu apelo em prol } \\
\text { da imediata cessação de hostilidades, da } \\
\text { proteção das populações civis e do pronto } \\
\text { reinício do diálogo entre as facções palestinas } \\
\text { como condição essencial à retomada do } \\
\text { processo de paz na região. } \\
\text { - Estabelecimento de um Estado palestino } \\
\text { soberano, geograficamente coeso e } \\
\text { economicamente viável. }\end{array}$ \\
\hline 14.9 .2007 & $\begin{array}{l}\text { Seminário sobre Paz e } \\
\text { Reconciliação - Brasil e } \\
\text { Noruega. Objetivo de } \\
\text { intercâmbio de } \\
\text { experiências e percepções } \\
\text { acerca do conflito entre } \\
\text { israelenses e palestinos }\end{array}$ & $\begin{array}{l}\text { - } \begin{array}{l}\text { Para o Brasil, iniciativas unilaterais não são a } \\
\text { resposta. }\end{array} \\
\text { - } \begin{array}{l}\text { A comunidade internacional tem a obrigação de } \\
\text { trabalhar com as partes envolvidas, com vistas a } \\
\text { assegurar o caminho do diálogo. }\end{array} \\
\text { - } \begin{array}{l}\text { O Brasil propôs a constituição de um Grupo de } \\
\text { Amigos para a Paz no Oriente Médio, } \\
\text { coordenado pelo SG da ONU. }\end{array}\end{array}$ \\
\hline 21.9 .2007 & $\begin{array}{l}\text { Chegada ao Brasil de } \\
\text { grupo de refugiados } \\
\text { palestinos }\end{array}$ & $\begin{array}{l}117 \text { refugiados foram reassentados em São } \\
\text { Paulo e no Rio Grande do Sul. A decisão do } \\
\text { Governo brasileiro foi fundamentada em razões } \\
\text { humanitárias. }\end{array}$ \\
\hline 23.11 .2007 & $\begin{array}{l}\text { Participação do Brasil na } \\
\text { Conferência de Annapolis. } \\
\text { Retomada do processo de } \\
\text { paz no Oriente Médio }\end{array}$ & $\begin{array}{l}\text { O Brasil esforçou-se para que a Conferência de } \\
\text { Annapolis representasse passo decisivo para o } \\
\text { envolvimento abrangente da comunidade } \\
\text { internacional no processo de paz. } \\
\text { - O Governo brasileiro defende que vozes } \\
\text { moderadas devem ser fortalecidas. }\end{array}$ \\
\hline
\end{tabular}




\begin{tabular}{|c|c|c|}
\hline 6.2 .2008 & $\begin{array}{l}\text { Atentado suicida em } \\
\text { Dimona, Israel }\end{array}$ & $\begin{array}{l}\text { O Brasil exorta palestinos e israelenses a exercer } \\
\text { a autocontenção e a manter o diálogo de modo a } \\
\text { evitar o aprofundamento da espiral de violência } \\
\text { na região e a preservar os esforços de retomada } \\
\text { do processo de paz manifestados nas } \\
\text { Conferências de Annapolis e de Paris. }\end{array}$ \\
\hline 19.6 .2008 & $\begin{array}{l}\text { Cessar-fogo na faixa de } \\
\text { Gaza e no sul de Israel }\end{array}$ & $\begin{array}{l}\text { Espera-se que a consolidação de ambiente de } \\
\text { calma e paz na região facilite a consecução de } \\
\text { avanços concretos no processo de paz e o } \\
\text { cumprimento dos entendimentos alcançados na } \\
\text { Conferência de Annapolis. }\end{array}$ \\
\hline 25.8 .2008 & $\begin{array}{l}\text { Libertação de } 198 \\
\text { prisioneiros palestinos por } \\
\text { Israel }\end{array}$ & $\begin{array}{l}\text { - O diálogo de paz foi inaugurado na Conferência } \\
\text { de Annapolis, com vistas ao estabelecimento de } \\
\text { um Estado palestino independente, em convívio } \\
\text { harmônico com Israel. } \\
\text { - } \quad \begin{array}{l}\text { O Brasil espera que essa decisão fortaleça a } \\
\text { confiança entre israelenses e palestinos. }\end{array} \\
\text { - Defende-se o estabelecimento do Estado } \\
\text { palestino independente em convívio harmônico } \\
\text { com Israel. }\end{array}$ \\
\hline 6.11 .2008 & Enfrentamentos em Gaza & $\begin{array}{l}\text { - O Brasil insta as partes envolvidas a cessar, de } \\
\text { forma imediata, os atos de hostilidade. } \\
\text { - Permite-se a manutenção da trégua, essencial } \\
\text { para a mitigação da grave situação humanitária } \\
\text { na Faixa de Gaza. } \\
\text { - Prosseguem os esforços de paz em curso, no } \\
\text { âmbito dos entendimentos alcançados na } \\
\text { Conferência de Annapolis. }\end{array}$ \\
\hline 3.1 .2009 & $\begin{array}{l}\text { Ofensiva terrestre } \\
\text { israelense em Gaza }\end{array}$ & $\begin{array}{l}\text { O Governo brasileiro apoia os esforços, } \\
\text { inclusive do CSNU, por cessar-fogo imediato, } \\
\text { de modo a permitir a pronta retomada do } \\
\text { processo de paz. } \\
\text { A realização de uma conferência internacional } \\
\text { em seguimento à reunião de Annapolis } \\
\text { constituiria passo importante para o } \\
\text { restabelecimento da paz na região, com base no } \\
\text { reconhecimento do direito de constituição do } \\
\text { Estado palestino e da existência de Israel em } \\
\text { condições de segurança. }\end{array}$ \\
\hline
\end{tabular}




\begin{tabular}{|c|c|c|c|}
\hline 15.1 .2009 & $\begin{array}{l}\text { Ataque a instalações das } \\
\text { Nações Unidas em Gaza }\end{array}$ & & $\begin{array}{l}\text { O ministro Celso Amorim reiterou a autoridades } \\
\text { sírias, israelenses, palestinas, jordanianas e } \\
\text { egípcias a necessidade de imediato cumprimento } \\
\text { da Resolução } 1860 \text { (2009) do CSNU, que impõe } \\
\text { a cessação imediata das hostilidades, único meio } \\
\text { de evitar mais mortes e sofrimento entre a } \\
\text { população civil de ambos os lados. }\end{array}$ \\
\hline 16.1 .2009 & $\begin{array}{l}\text { Situação em Gaza. Novos } \\
\text { contatos do ministro Celso } \\
\text { Amorim }\end{array}$ & - & $\begin{array}{l}\text { O ministro Celso Amorim manteve contato } \\
\text { telefônico com o Alto Representante da União } \\
\text { Europeia para Política Externa, Javier Solana, o } \\
\text { ministro dos Negócios Estrangeiros da Turquia, } \\
\text { Ali Babacan, o MRE do Chile, Alejandro } \\
\text { Foxley, o MNE da França, Bernard Koucher, e o } \\
\text { MNE da Noruega, Jonas Store. } \\
\text { O ministro Amorim reitera a necessidade do } \\
\text { cumprimento imediato da Resolução } 1860 \\
\text { (2009) do CSNU, que pede o fim das } \\
\text { hostilidades, e a preocupação brasileira com a } \\
\text { degradação da situação humanitária na Faixa de } \\
\text { Gaza. }\end{array}$ \\
\hline 17.1.2009 & $\begin{array}{l}\text { Cessar-fogo unilateral, } \\
\text { decretado pelas } \\
\text { autoridades israelenses na } \\
\text { Faixa de Gaza. }\end{array}$ & - & $\begin{array}{l}\text { O Brasil reitera a disposição em continuar a } \\
\text { participar dos esforços internacionais que } \\
\text { conduzam à criação de um Estado palestino } \\
\text { viável em coexistência pacífica com o Estado de } \\
\text { Israel. } \\
\text { O Governo brasileiro sublinha ser fundamental o } \\
\text { cumprimento de todas as resoluções do CSNU, } \\
\text { em particular a Resolução } 1860 \text {, de } 2009 \text {. }\end{array}$ \\
\hline 23.1 .2009 & $\begin{array}{l}\text { Doação humanitária à } \\
\text { Palestina }\end{array}$ & - & $\begin{array}{l}\text { O Governo brasileiro acompanha, com atenção, } \\
\text { a situação em Gaza. Considera fundamental a } \\
\text { plena implantação da Resolução } 1860 \text { (2009) do } \\
\text { CSNU como forma de alcançar cessar-fogo } \\
\text { sólido e duradouro. } \\
\text { De imediato e dada a situação especialmente } \\
\text { grave da população civil em Gaza, exorta o } \\
\text { Governo de Israel a permitir, sem qualquer tipo } \\
\text { de restrição, o fluxo de assistência humanitária. }\end{array}$ \\
\hline 2.2 .2009 & $\begin{array}{l}\text { Violência na Faixa de } \\
\text { Gaza }\end{array}$ & & $\begin{array}{l}\text { O Brasil considera que a violência dificulta o } \\
\text { acesso da assistência humanitária internacional e } \\
\text { prejudica os esforços em favor de solução } \\
\text { negociada, pacífica e sustentável para o conflito. } \\
\text { O Brasil reitera a necessidade do pleno } \\
\text { cumprimento da Resolução } 1860 \text { (2009) do } \\
\text { CSNU. }\end{array}$ \\
\hline
\end{tabular}




\begin{tabular}{|c|c|c|}
\hline 2.3 .2009 & $\begin{array}{l}\text { Conferência Internacional } \\
\text { em apoio à Economia } \\
\text { Palestina para a } \\
\text { Reconstrução de Gaza } \\
\text { (Sharm El-Sheik, Egito) }\end{array}$ & $\begin{array}{l}\text { - O Brasil defende a Conferência para estabelecer } \\
\text { um Estado palestino viável, em uma etapa } \\
\text { inicial, convivendo lado a lado e em paz com } \\
\text { Israel. } \\
\text { - A ajuda humanitária e o comércio normal e } \\
\text { legítimo devem circular livremente, em Gaza }{ }^{129} \text {. } \\
\text { - O Brasil conclama que devem ser interrompidos } \\
\text { os graves obstáculos à solução da coexistência } \\
\text { dos dois Estados, de que são exemplos a } \\
\text { expansão dos assentamentos por Israel e o } \\
\text { frequente uso da força. } \\
\text { - O Brasil defende que os países em } \\
\text { desenvolvimento fora da região sejam } \\
\text { incorporados às discussões. } \\
\text { Durante a Conferência, o Brasil anunciou a } \\
\text { doação de US\$ } 10 \text { milhões para a reconstrução } \\
\text { de Gaza }{ }^{130} \text {. }\end{array}$ \\
\hline 3.8 .2009 & $\begin{array}{l}\text { Despejo de palestinos em } \\
\text { Jerusalém Oriental }\end{array}$ & 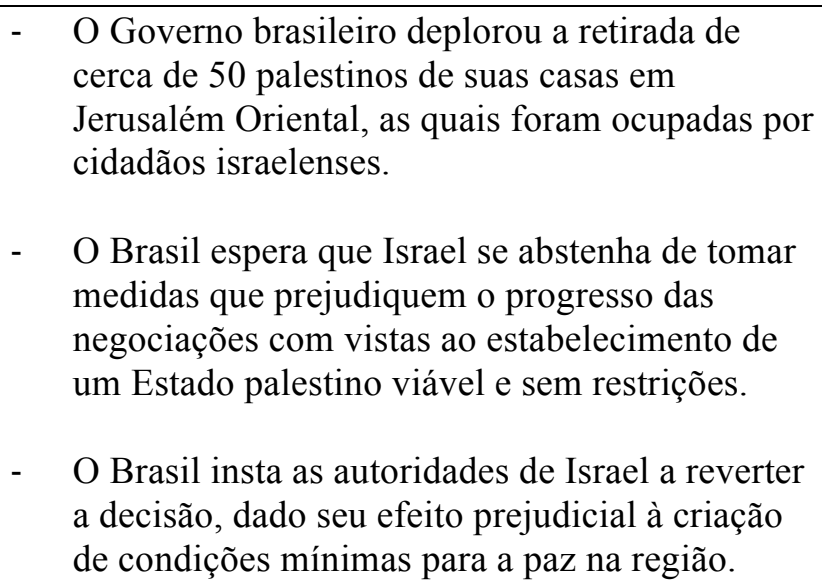 \\
\hline 19.11 .2009 & $\begin{array}{l}\text { Visita ao Brasil pelo } \\
\text { Presidente da Autoridade } \\
\text { Nacional Palestina, } \\
\text { Mahmoud Abbas }\end{array}$ & $\begin{array}{l}\text { Ademais de contribuir para fortalecer os laços } \\
\text { bilaterais, a visita servirá para renovar o diálogo } \\
\text { a respeito do processo de paz israelo-palestino e } \\
\text { reiterar a disposição brasileira em colaborar com } \\
\text { os esforços da comunidade internacional em } \\
\text { promover o entendimento e a paz na região. }\end{array}$ \\
\hline 19.11 .2009 & $\begin{array}{l}\text { Expansão de assentamento } \\
\text { na Cisjordânia }\end{array}$ & 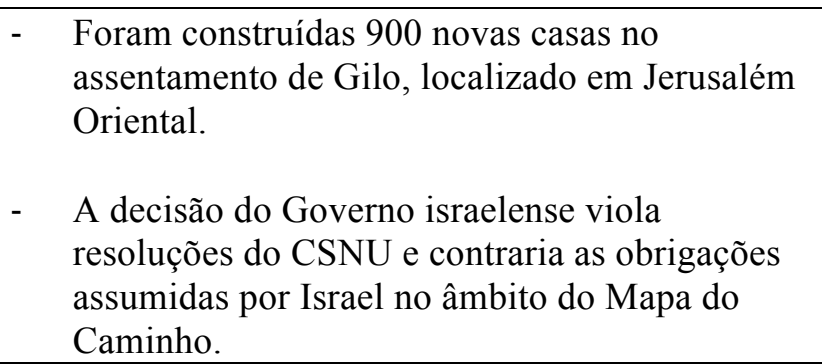 \\
\hline
\end{tabular}

\footnotetext{
${ }^{129}$ Implantação da Resolução 1860, do Conselho de Segurança das Nações Unidas.

${ }^{130}$ O Presidente Lula pediu ao Congresso que autorizasse a doação em caráter de urgência.
} 


\begin{tabular}{|c|c|c|c|}
\hline & & & $\begin{array}{l}\text { Essa iniciativa representa duro golpe nos } \\
\text { esforços internacionais que visam à retomada do } \\
\text { processo de paz na região e constitui obstáculo à } \\
\text { consecução do objetivo do futuro Estado } \\
\text { palestino geograficamente coeso e } \\
\text { economicamente viável. } \\
\text { O Brasil conclama Israel a rever a decisão } \\
\text { anunciada, de modo a ampliar as condições } \\
\text { políticas para que israelenses e palestinos } \\
\text { voltem à mesa de negociações. }\end{array}$ \\
\hline 5.1 .2010 & $\begin{array}{l}\text { Encontro do ministro } \\
\text { Celso Amorim com o } \\
\text { ministro dos Negócios } \\
\text { Estrangeiros da Palestina }\end{array}$ & - & $\begin{array}{l}\text { Os dois ministros dão seguimento a conversas } \\
\text { sobre temas bilaterais e sobre o processo de paz } \\
\text { israelo-palestino. }\end{array}$ \\
\hline 12.3 .2010 & $\begin{array}{l}\text { Construção de } 1600 \text { novas } \\
\text { unidades habitacionais em } \\
\text { Jerusalém Oriental e } 112 \\
\text { moradias na Cisjordânia }\end{array}$ & - & $\begin{array}{l}\text { O Brasil lamentou a autorização para novas } \\
\text { construções em assentamentos, especialmente } \\
\text { nesse momento em que as conversações entre } \\
\text { israelenses e palestinos poderiam recomeçar. }\end{array}$ \\
\hline 12.3 .2010 & $\begin{array}{l}\text { Visita do Presidente Luiz } \\
\text { Inácio Lula da Silva a } \\
\text { Israel, Territórios } \\
\text { Palestinos ocupados e } \\
\text { Jordânia }\end{array}$ & - & $\begin{array}{l}\text { A primeira visita de um Presidente brasileiro a } \\
\text { Israel, Palestina e Jordânia reflete a crescente } \\
\text { aproximação do Brasil a países do Oriente } \\
\text { Médio. Entre os temas internacionais a ser } \\
\text { tratados, estão a retomada das negociações } \\
\text { israelo-palestinas e a disposição do Brasil de } \\
\text { contribuir para o encaminhamento do processo } \\
\text { de paz no Oriente Médio. }\end{array}$ \\
\hline 15.4 .2010 & $\begin{array}{l}\text { Reunião de ministros do } \\
\text { IBAS com o chanceler da } \\
\text { autoridade nacional } \\
\text { Palestina }\end{array}$ & - & $\begin{array}{l}\text { Os três países do IBAS têm mantido } \\
\text { coordenação em temas relacionados ao processo } \\
\text { de paz no Oriente Médio, desde } 2004 \text {. } \\
\text { Por meio do fundo IBAS, os três países } \\
\text { constroem um centro esportivo na cidade de } \\
\text { Ramalah, ao custo de US\$ } 1 \text { milhão. } \\
\text { A situação dos direitos humanos nos territórios } \\
\text { palestinos ocupados foi objeto de intervenções } \\
\text { conjuntas do IBAS no Conselho de Direitos } \\
\text { Humanos da ONU, em março e setembro de } \\
2009 \text {. }\end{array}$ \\
\hline 15.4 .2010 & $\begin{array}{l}\text { Comunicado conjunto dos } \\
\text { ministros do IBAS sobre a } \\
\text { situação no Oriente Médio }\end{array}$ & & $\begin{array}{l}\text { The IBSA countries call for the urgent } \\
\text { resumption of negotiations that will lead to a } \\
\text { two-state solution, with the creation of a } \\
\text { sovereign, democratic, independent, united and } \\
\text { viable Palestinian state, coexisting peacefully } \\
\text { alongside Israel, within secure, pre-1967 } \\
\text { borders, with East Jerusalem as its capital. }\end{array}$ \\
\hline
\end{tabular}




\begin{tabular}{|c|c|c|}
\hline & & $\begin{array}{l}\text { - The IBSA countries strongly urge the Israeli } \\
\text { government to freeze all settlement activity in } \\
\text { the occupied Palestinian territories, including } \\
\text { "natural growth", and to reverse its decision to } \\
\text { advance planning for new housing units in East } \\
\text { Jerusalem. } \\
\text { - They express support for mediation efforts with } \\
\text { a view to reaching domestic Palestinian } \\
\text { reconciliation and urge all interested parties to } \\
\text { contribute to that purpose. They call on the } \\
\text { international community to contribute, on } \\
\text { sustained, concrete and urgent basis, to the state- } \\
\text { building efforts undertaken by the Palestinian } \\
\text { National Authority, recalling the IBSA readiness } \\
\text { to continue its commitments in this regard. }\end{array}$ \\
\hline 31.5 .2010 & $\begin{array}{l}\text { Ataque israelense à } \\
\text { "Flotilha da Liberdade" }\end{array}$ & $\begin{array}{l}\text { - Com choque e consternação, o Governo } \\
\text { brasileiro recebeu a notícia do ataque israelense } \\
\text { a um dos barcos da flotilha que levava ajuda } \\
\text { humanitária internacional à Faixa de Gaza, do } \\
\text { qual resultou a morte de mais de uma dezena de } \\
\text { pessoas, além de feridos em outros integrantes. } \\
\text { - "O Brasil condena, em termos veementes, a ação } \\
\text { israelense, uma vez que não há justificativa para } \\
\text { intervenção militar em comboio pacífico, de } \\
\text { caráter estritamente humanitário”. } \\
\text { É necessário que seja levantado o bloqueio } \\
\text { imposto à Faixa de Gaza, com vistas a garantir a } \\
\text { liberdade de locomoção de seus habitantes e o } \\
\text { livre acesso de alimentos, remédios e bens de } \\
\text { consumo àquela região. } \\
\text { - Uma cidadã brasileira estava numa das } \\
\text { embarcações que compunha a flotilha } \\
\text { humanitária. O embaixador de Israel no Brasil } \\
\text { foi chamado ao Itamaraty para que seja } \\
\text { manifestada a indignação do governo brasileiro } \\
\text { com o incidente e a preocupação com a situação } \\
\text { da cidadã brasileira. }\end{array}$ \\
\hline 25.8 .2010 & $\begin{array}{l}\text { Retomada do diálogo } \\
\text { direto entre israelenses e } \\
\text { palestinos }\end{array}$ & $\begin{array}{l}\text { - O Brasil acredita que, apenas por meio da } \\
\text { negociação e do entendimento, será possível } \\
\text { alcançar uma solução justa e definitiva para o } \\
\text { conflito israelo-palestino. } \\
\text { - A solução deverá contemplar a criação de um } \\
\text { Estado palestino independente, democrático, } \\
\text { coeso e economicamente viável, convivendo em } \\
\text { paz e segurança com Israel. }\end{array}$ \\
\hline
\end{tabular}




\begin{tabular}{|c|c|c|}
\hline & & $\begin{array}{l}\text { A solução deverá basear-se no Mapa do } \\
\text { Caminho, nos princípios de Madri, nas } \\
\text { resoluções do CSNU e na Iniciativa Árabe de } \\
\text { Paz. }\end{array}$ \\
\hline $1^{\circ} .9 .2010$ & Atentado na Cisjordânia & $\begin{array}{l}\text { - O Brasil condena atos de violência. } \\
\text { - A expectativa brasileira é a de que lideranças } \\
\text { israelenses e palestinas permaneçam engajadas } \\
\text { na busca da paz justa, que contemple a criação } \\
\text { do Estado palestino independente, democrático, } \\
\text { coeso e economicamente viável, convivendo em } \\
\text { segurança com Israel. }\end{array}$ \\
\hline 28.9 .2010 & $\begin{array}{l}\text { Fim da moratória de } \\
\text { expansão de } \\
\text { assentamentos em } \\
\text { territórios palestinos } \\
\text { ocupados }\end{array}$ & 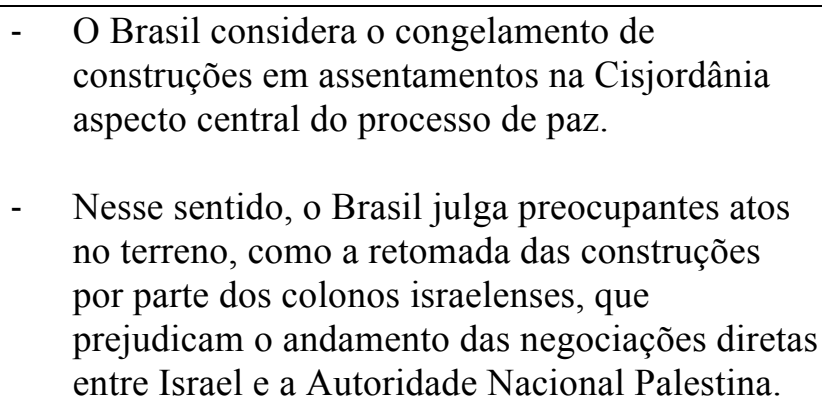 \\
\hline 3.12 .2010 & $\begin{array}{l}\text { Reconhecimento do } \\
\text { Estado palestino nas } \\
\text { fronteiras de } 1967\end{array}$ & $\begin{array}{l}\text { Por meio de carta enviada pelo Presidente Lula } \\
\text { ao Presidente Abbas, da ANP, o governo } \\
\text { brasileiro reconheceu o Estado palestino nas } \\
\text { fronteiras existentes em } 1967 .\end{array}$ \\
\hline
\end{tabular}

\subsubsection{O reconhecimento do Estado palestino pelo Brasil}

O último ato internacional de impacto do governo do Presidente Lula foi o reconhecimento, em $1^{\circ}$ de dezembro de 2010, do Estado palestino nas fronteiras de 1967. O pronto ato foi em resposta ao pedido de reconhecimento feito pelo Presidente Mahmoud Abbas ao Presidente Lula por meio de carta enviada à chancelaria brasileira, em 24 de novembro de 2010. O pedido palestino ao governo brasileiro adveio da seguinte maneira:

Enquanto expressamos a Vossa Excelência o nosso orgulho das valorosas e históricas relações brasileiro-palestinas, que refletem suas posições firmes em relação ao nosso povo, ao longo dos anos e em nossos recentes encontros, esperamos, nosso caro amigo, que Vossa Excelência decida tomar a iniciativa de reconhecer o Estado da Palestina nas fronteiras de $1967^{131}$.

\footnotetext{
${ }^{131}$ Grifo nosso.
} 
A importância dessa tomada de decisão pelo governo brasileiro, segundo Abbas, deve-se ao fato de que encorajará outros países no continente sul-americano e em outras regiões do mundo a seguir a posição de reconhecer o Estado palestino. De acordo com o Presidente da Autoridade Nacional Palestina, essa decisão levará ao avanço do processo de paz e à promoção da posição palestina, que busca o reconhecimento internacional de seu Estado. No fechamento de sua carta ao Presidente Lula, o Presidente Abbas afirma que espera seu pedido receber a bondosa aceitação do Estado brasileiro e essa iniciativa ser tomada antes do fim de seu mandato presidencial.

A resposta ao Presidente da ANP veio rápida, apenas uma semana depois e também por meio de Carta, segundo a qual o governo brasileiro argumentou ter defendido, historicamente, em particular, durante o governo Lula, a concretização da legítima aspiração do povo palestino a um Estado coeso, seguro, democrático e economicamente viável, coexistindo em paz, com Israel. O reconhecimento efetivo ocorreu por meio das seguintes palavras do Presidente Lula: "Por considerar que a solicitação apresentada por Vossa Excelência é justa e coerente com os princípios defendidos pelo Brasil para a questão palestina ${ }^{132}$, o Brasil, por meio desta carta, reconhece o Estado palestino nas fronteiras de 1967”.

De forma a reforçar a concepção do papel nacional brasileiro de "mediador de conflitos" ou "construtor de consensos", o Brasil posicionou-se em relação à questão palestina e, mais uma vez, ofereceu seus préstimos de mediação. De acordo com o Presidente Lula, "o reconhecimento palestino é parte da convicção do Brasil de que um processo negociador que resulte em dois Estados convivendo pacificamente e em segurança é o melhor caminho para a paz no Oriente Médio - objetivo que interessa a toda a humanidade".

Segundo nota 707 à imprensa, expedida pelo Itamaraty em 3 de dezembro de 2010, a iniciativa de reconhecimento do Estado palestino nas fronteiras de 1967 é coerente com a disposição histórica do Brasil de contribuir para o processo de paz entre Israel e Palestina, cujas negociações diretas, à época, estavam interrompidas. A ação esteve em consonância com as resoluções da ONU de 4 de junho de 1967, que exigiam o fim da ocupação dos territórios palestinos e a construção de um Estado independente nas fronteiras. Na mesma nota, o governo brasileiro expressou sua

\footnotetext{
${ }^{132}$ Grifo nosso.
} 
vontade de que mais países entrassem na discussão, ao considerar que o apoio de países extrarregionais à solução de dois Estados fosse fundamental para legitimar a via negociadora como único meio para chegar-se ao fim da ocupação.

Inspirados pelo protagonismo brasileiro em reconhecer o Estado da Palestina, uma movimentação ocorreu na América do Sul. Entre 6 de dezembro de 2010 e 14 de fevereiro de 2011, oito estados sul-americanos assim o fizeram: Argentina, Uruguai, Bolívia, Equador, Chile, Guiana, Peru e Paraguai. A Argentina e o Uruguai acompanharam o Brasil em sua decisão de reconhecer o Estado palestino no dia 6 de dezembro de $2010^{133}$. O Estado boliviano, por meio do Presidente Evo Morales, reconheceu o Estado da Palestina durante a I Cúpula ASPA, em 17 de dezembro de $2010^{134}$. O Equador, quarto Estado a reconhecer a Palestina como independente, fê-lo em 25 de dezembro de $2010^{135}$. O Chile ${ }^{136}$ e a Guiana reconheceram a Palestina, respectivamente, nos dias 8 e 14 de janeiro de 2011. Os últimos Estados sulamericanos a reconhecer a Palestina, o Peru ${ }^{137}$ e o Paraguai, fizeram-no, respectivamente, nos dias 25 e 30 de janeiro de 2011. O Peru anunciou seu reconhecimento por meio do chanceler José Antonio Garcia Belaunde, que decidiu reconhecer a Palestina “como Estado livre e soberano". O Paraguai ${ }^{138}$, o último país na América do Sul a oficializar o reconhecimento da Palestina, fê-lo durante a Cúpula ASPA, em Lima, em 14 de fevereiro de 2011.

A percepção internacional do papel nacional brasileiro ao reconhecimento do Estado da Palestina foi intensa e veio em ato quase contínuo. Israel, por exemplo, reagiu, de forma violenta, ao reconhecimento do Estado da Palestina pelo Brasil, pela Argentina e pelo Uruguai, considerando o fato grande interferência pelos países que nunca foram parte do processo de paz no Oriente Médio. De acordo com o chanceler

\footnotetext{
${ }^{133}$ Brazil, Argentina and Uruguay Recognize Palestinian State. Agência France Presse. Paris, 7 de dezembro de 2010.

134 Abbas: Ecuador Will Follow Bolivia in Recognizing Palestine. Palestine News Network. Jerusalém, 18 December, 2010. Acesso em: 14 de outubro de 2014.

${ }^{135}$ Ecuador Recognizes Palestine State. Agência France Presse. Paris, 25 December, 2010. Acesso em: 14 de outubro de 2014.

${ }^{136}$ BARRIONUEVO, Alexei. Chile offers recognition for a State of Palestine. The New York Times. Nova York, 8th January 2011. Disponível em: < http://www.nytimes.com/2011/01/08/world/americas/08chile.html?_r=0>. Acesso em: 14 de outubro de 2014.

${ }^{137}$ Peru Formally Recognizes Palestinian State. Ha'aretz. Tel Aviv, $25^{\text {th }}$ January 2011. Disponível em: $<$ http://www.haaretz.com/news/diplomacy-defense/peru-formally-recognizes-palestinian-state1.338976>. Acesso em: 14 de outubro de 2014.

${ }^{138}$ Oficializarán reconocimiento a Palestina. ABC Color. Asunción, 30 de enero de 2011. Disponível em: $\quad<$ http://www.abc.com.py/edicion-impresa/politica/oficializaran-reconocimiento-a-palestina214147.html >. Acesso em: 14 de outubro de 2014.
} 
judeu à época, Yigal Palmor, os Estados sul-americanos nunca tinham contribuído para o processo de paz no Oriente Médio e estavam fazendo o contrário do que fora acordado $^{139}$. O porta-voz do Ministério das Relações Exteriores israelense considerou as declarações brasileiras unilaterais e contraprodutivas ${ }^{140}$.

Para a administração democrata dos Estados Unidos, nesse sentido, a única forma de alcançar a paz na região seria mediante negociações diretas entre israelenses e palestinos ${ }^{141}$. O subsecretário de Estado, Willian Burns, afirmou: "Brazil's and Argentina's recognition of a Palestinian State is premature". Por sua vez, a Câmara de Representantes dos EUA aprovou resolução que condena as medidas unilaterais que declaram ou reconhecem o Estado palestino, respaldando solução negociada ao conflito entre israelenses e palestinos ${ }^{142}$. Na opinião do ex-presidente americano Jimmy Carter, o Brasil estava certo em reconhecer o Estado palestino e pode desempenhar papel significativo no processo de paz do Oriente Médio. De acordo com Carter, o Brasil pode e deverá ter um papel cada vez maior e mais relevante no Oriente Médio $^{143}$. Acerca do reconhecimento em cadeia da Palestina pelos países sulamericanos, Israel e o governo norte-americano declararam que a atitude dos países sul-americanos em reconhecer um Estado palestino nas fronteiras pré-1967 seria um obstáculo às negociações de paz, notando que as resoluções das Nações Unidas chamam para uma solução negociada para o conflito Israel - Palestina ${ }^{144}$.

O reconhecimento pelo Brasil do Estado palestino, seguido de onda regional de reconhecimentos na América do Sul, pode ser considerado o maior sucesso da política externa brasileira no que diz respeito a sua influência no Oriente Médio, durante os anos Lula. Para além da intensa exposição midiática do gesto, o ato de

\footnotetext{
${ }^{139}$ Israel says South American Palestinian nod shurt Peace. Agência Reuters. Reino Unido, 7 de dezembro de 2010. Acesso em: 14 de outubro de 2014.

${ }^{140}$ GOFORTH, Sean. Brazil's Middle East Road Map. World Politics Review, EUA, 20th January 2011. Disponível em: < http://www.worldpoliticsreview.com/articles/7612/brazils-middle-east-roadmap >. Acesso em: 14 de outubro de 2014.

${ }^{141}$ PISANI, Silvia. Cuestiona EEUU el reconocimiento del Estado palestino. La Nación. Buenos Aires, 8 deciembre 2010. Disponível em: <http://www.lanacion.com.ar/1331667-cuestiona-eeuu-elreconocimiento-del-estado-palestino >. Acesso em: 14 de outubro de 2014.

${ }^{142}$ Congresso dos EUA rejeita declaração do Brasil sobre Estado palestino. Agência France Presse, Paris, 17 de dezembro de 2010. Disponível em: < http:// terra.com.br/interna/0,,OI4847039EI12822,00.html >. Acesso em: 14 de outubro de 2014.

${ }^{143}$ Brazil can be crucial to Middle East Peace process, says Jimmy Carter. The Daily Telegraph. Londres, 21 de dezembro de 2010. Disponível em: < http://www.telegraph.co.uk/news/worldnews/southamerica/brazil/8214929/Brazil-can-be-crucial-toMiddle-East-peace-process-says-Jimmy-Carter.html>. Acesso em: 14 de outubro de 2014.

${ }^{144}$ OPPENHEIMER, Andrés. Opinion: South America enters Middle East quagmire. The New York Times. New York, $9^{\text {th }}$ January 2011. Disponível em: $<$ http://www.ihavenet.com/Latin-AmericaSouth-America-Enters-Middle-East-Quagmire-AO.html >. Acesso em: 14 de outubro de 2014.
} 
reconhecimento pode ser considerado coerente, pois refletiu um alinhamento de princípios entre as tradições históricas do Partido dos Trabalhadores e a ação da diplomacia brasileira. Ademais, o reconhecimento da Palestina refletiu o papel de liderança do Brasil na América do Sul, pois o ato da diplomacia brasileira influenciou a mesma decisão em mais oito chancelarias sul-americanas.

\subsection{A mediação brasileira na questão nuclear iraniana}

Apesar de, à primeira vista, parecer exóticas e distantes, as relações entre o Brasil e Irã datam de longa data e foram estabelecidas diplomaticamente em 1903, durante o governo Rodrigues Alves, à época da República Velha. Foi no segundo mandato do Presidente Lula, no entanto, que essas relações foram exponencialmente fortalecidas. Dessa forma, de 2007 a 2010, a prioridade conferida ao Irã traduziu-se em uma série de trocas de visitas de altas autoridades dos dois países e em diversas iniciativas conjuntas. O chanceler Celso Amorim, por exemplo, visitou o Irã por quatro vezes ${ }^{145}$. Em novembro de 2009, o Presidente iraniano Mahmoud Ahmadinejad veio ao Brasil, e, em maio de 2010, o Presidente Lula retribui a visita e esteve em Teerã.

Com a ruptura das relações entre Irã e EUA e o consequente embargo imposto pelos americanos, o Irã começou a reconstruir seu lugar no contexto internacional. Segundo análise de Élodie Brun (2011), o Irã passou a atrair olhares dos diversos atores do sistema internacional por conta de seu projeto de inserção internacional atípico e de suas relações conturbadas com os EUA. Esse posicionamento iraniano veio ao encontro do novo estilo de diplomacia definida pelo governo Lula de reforço das relações Sul-Sul e desejosa por desempenhar papel ativo e representativo no sistema internacional, em especial no que diz respeito à mediação de questões relativas à segurança internacional.

Dessa forma, pode-se afirmar que a aproximação entre o Brasil e o Irã, a partir de 2007, está inscrita em um contexto de reorientação ampla da diplomacia brasileira que ultrapassa o planejamento das visitas diplomáticas, pois o Brasil também modificou certas tomadas de decisão em favor do Irã, como, por exemplo, o rápido

\footnotetext{
${ }^{145}$ As visitas realizadas pelo ministro Celso Amorim ao Irã prepararam o terreno para uma articulação entre Brasil, Turquia e Irã, em torno de uma solução para a questão nuclear iraniana, que culminou com a Declaração de Teerã, de 17 de maio de 2010.
} 
reconhecimento do resultado das eleições presidenciais de maio de 2009 e o voto de abstenção no âmbito da ONU, por ocasião da condenação da situação dos direitos humanos no Irã (BRUN, 2011). De acordo com Muxagato (2010), a legitimidade do Brasil em envolver-se na questão nuclear iraniana adveio do fato de que ambos Brasil e Irã - são países do Sul e em desenvolvimento: "Spécifiquement sur le thème du nucléaire iranien, le géant sud-américain peut se poser comme un arbitre légitime étant un pays du Sud développant et avec un programme nucléaire civil à des seules fins pacifiques".

A aliança brasileira com a Turquia em torno da resolução do impasse acerca da questão nuclear iraniana ocorreu quase naturalmente, durante a ocupação de suas concomitantes cadeiras não permanentes no $\mathrm{CSNU}^{146}$. Segundo Turan (2010), o que uniu Brasil e Turquia foi o desejo em comum de efetuar mudanças no sistema de governança global e de ampliar suas respectivas influências no funcionamento desse sistema. De acordo com o atual primeiro-ministro turco e ex-chanceler, Ahmet Davutoglu (2012), Brasil e Turquia têm a mesma compreensão de que, apenas com o aprofundamento da sensação de pertencimento regional, será possível criar cinturões de paz e de prosperidade em suas regiões.

Como atores regionais com grande interesse na paz e na estabilidade, Brasil e Turquia passaram, recentemente, a reivindicar maiores responsabilidades em suas respectivas regiões e além. Segundo Parsi (2013: 172-209), o poder da aliança entre Brasil e Turquia não foi calculado nem mesmo pelo Departamento de Estado, que não levou em consideração as habilidades diplomáticas turcas e brasileiras e o seu intenso desejo por demonstrar habilidade em enfrentar desafios diplomáticos normalmente reservados às grandes potências.

Diversos acadêmicos ensaiaram análises acerca das reais motivações que levaram Brasil e Turquia, separadamente e em conjunto, a envolver-se, de forma tão intensa, na questão nuclear iraniana. Entre as motivações turcas, isoladamente, são seis as que mais se destacam: desejo de elevar o perfil internacional da Turquia; vontade de aumentar o papel da liderança do Estado turco no mundo; plano turco de tornar-se corredor de transporte de energia para a Europa; garantia de acesso da Turquia ao estratégico território do Irã, que é uma das principais rotas de circulação entre a Turquia e a Ásia Central; impedimento de que os EUA ou Israel justifiquem

\footnotetext{
${ }^{146}$ Em outubro de 2008, a Turquia foi eleita para o Conselho de Segurança das Nações Unidas como membro não permanente para o período entre 2009 e 2010.
} 
uma operação militar com o pretexto de que o Irã não esteja disposto à solução diplomática; impedimento de que o Irã justifique maior avanço em suas capacidades nucleares, enriquecendo o LEU até $20 \%$, sob o pretexto de não receber apoio do restante do mundo (AZAMBUJA, 2010; TURAN, 2010; KIBAROGLU, 2010; PARSI, 2013).

No que diz respeito ao Brasil, os autores são categóricos, ao afirmar quatro grandes motivações da política externa brasileira ao envolvimento na questão nuclear iraniana: oportunidade para aumentar o prestígio, a voz e o reconhecimento no contexto internacional; ambição brasileira em aumentar seu poder de influência no sistema internacional, haja vista que o Irã focaliza a atenção internacional em razão de seu contencioso com as potências ocidentais acerca do programa nuclear; reforma das estruturas da governança global; demanda por assento permanente no CSNU (AZAMBUJA, 2010; WERZ, 2010; BRUN, 2011; PARSI, 2013). Segundo, análise de Parsi (2013), os objetivos brasileiros de reforma da governança global e de assento permanente no CSNU estão intimamente relacionados ao aumento de interesse e de atuação do Brasil no Irã:

\footnotetext{
For Lula, gaining greater voice and recognition as a major player in international scene was not enough. With that role came the responsibility to change the status quo for the better. "There is a major deficit of governance in this international order. We cannot continue like this. For Brazil, Iran became the vehicle to achieve this larger goal (...) but for the Brazilian government, it could not couple its demand for a permanent seat at the UNSC, with continued indifference to matters of world peace. "What do we want to become a member on the Security Council for if we don't have anything to say about the Middle East?" (grifo nosso)
}

As motivações em comum entre Brasil e Turquia que explicam o envolvimento desses dois países na questão nuclear iraniana, segundo Turan (2010) e Clinton (2014), são três principais: competição por liderança regional; desejo de ver reconhecidos seus pontos de vista sobre governança global; desejo de exercer maior influência sobre o contexto internacional. De acordo com a análise feita por Hillary Clinton (2014: 416-446), Brasil e Turquia são exemplos clássicos de potências emergentes cujo rápido crescimento econômico fez que fossem despertadas maiores ambições por influência regional e global. Segundo Clinton (2014), ambos os países coincidiram ter, no poder, dois presidentes muito confiantes, que se consideram homens de ação capazes de moldar a história de acordo com seus interesses. 
A estratégia diplomática do Brasil de aproximação a Teerã, mais especificamente, em relação às tentativas de mediação brasileira entre o Irã e a comunidade internacional, no que diz respeito à questão nuclear, baseou-se em duas premissas: o diálogo mais eficaz que o isolamento; o direito do Irã ao desenvolvimento e ao uso da energia nuclear para fins pacíficos (MUXAGATO, 2010; BRUN, 2011). Dessa forma, o governo brasileiro reiterou que o fortalecimento do diálogo é a única opção viável para o tratamento da questão nuclear iraniana, devendo-se evitar, a todo custo, a estratégia de isolamento e de exclusão do Irã da mesa de negociações. Em entrevista concedida pelo ministro Celso Amorim à revista Carta Capital em 11 de maio de 2009, a opção ao diálogo pela diplomacia brasileira ficou bem evidenciada: "Não deixamos de criticar, mas é não nos recusarmos ao diálogo. É pelo diálogo que se pode ter influência sobre os países. Queiram ou não as pessoas, o Irã é um interlocutor importante para o Oriente Médio".

Segundo Amorim (2009), a melhor estratégia para alcançar progresso na resolução do problema iraniano é reconhecer o direito do Irã de promover sua indústria de energia atômica para fins civis, ou seja, legitimar o direito iraniano de desenvolver seu programa nuclear para objetivos pacíficos, com pleno respeito aos acordos internacionais. Em outra entrevista, dessa vez concedida à revista Caros Amigos, em $1^{\circ}$ de fevereiro de 2009, o chanceler Amorim afirmou (MRE, 2009a; MRE, 2009b): “O Brasil é contra a proliferação nuclear. Agora, é preciso distinguir a questão da não proliferação nuclear da questão do direito ao desenvolvimento da tecnologia nuclear para fins pacíficos".

Um dos pontos pouco mencionados pela literatura, mas que legitimou a ação do Brasil e da Turquia no que tange a questão nuclear iraniana foi a carta enviada pelo Presidente dos Estados Unidos ao governo brasileiro, datada de 20 de abril de 2010, que estabelecia as condições que Obama desejava ver cumpridas pelo Irã, como, por exemplo, a transferência de $1.200 \mathrm{~kg}$ de urânio levemente enriquecido para um terceiro país. A mensagem implicava, dessa forma, modelo de acordo com o qual os Estados Unidos acreditavam ser útil para a resolução do impasse nuclear iraniano. A carta indicava três pontos essenciais a ser negociados: questão da quantidade (1.200 $\mathrm{kg}$ ); tempo (o LEU deveria ser imediatamente embarcado); local (a troca de combustível nuclear deveria ser feita na Turquia). Com a carta em mão, o Presidente Lula embarcou a Teerã, cujo clima estava tenso em razão das perspectivas de sanções do CSNU (TURAN, 2010; PARSI, 2013). 
Em maio de 2010, tanto o tempo como a paciência da comunidade internacional, especialmente dos membros do $\mathrm{P} 5+1$, exauriam-se acerca do programa nuclear iraniano. Dessa forma, a conjuntura de pedido por sanções do CSNU contra o Irã estava cada vez mais definida. O emprego de uma opção militar começou a ser real, tendo apoio de grande parte da comunidade internacional. Contra esse clima prósanção, a Turquia e o Brasil aproveitaram o momento e encorajaram o Irã a um acordo baseado em propostas anteriores, feito em 2009 pelo P5+1.

Tendo a participação dos chanceleres turco e brasileiro, juntamente com o primeiro-ministro turco, Recep Tayyip Erdogan, e o presidente brasileiro Luiz Inácio Lula da Silva, o Irã assinou declaração conjunta com o Brasil e a Turquia, na qual o "Irã concordava em enviar urânio enriquecido para a Turquia em troca de combustível enriquecido para o reator nuclear" (OSKAN, 2011). Dessa forma, em 17 de maio de 2010, após 18 horas de negociações em Teerã, os líderes do Brasil e da Turquia anunciaram que haviam alcançado os princípios de um acordo para pôr fim ao impasse nuclear entre o Irã e a comunidade internacional. A essência do acordo foi uma troca de concessões que deram suporte para limitar o enriquecimento de urânio iraniano com a condição de que o Irã tivesse seus direitos reconhecidos de enriquecer urânio e de ter um programa nuclear pacífico. O Irã fez sua concessão logo no fim dos primeiro dia de negociações e demonstrou boa vontade em confiar seu urânio enriquecido ao governo turco (SOTERO, 2012).

A questão da confiança foi recorrente; não apenas existiu a desconfiança do Irã em relação aos EUA como também medo iraniano de que a Turquia cedesse à pressão de Washington e violasse os termos de troca. Havia, também, o receio de que a Turquia e o Brasil fracassassem em garantir a aceitação do acordo pelos EUA. Conforme o relato de Celso Amorim, a negociação foi bastante dura. Chegou-se a uma declaração final, na qual foram incluídos vários elementos de interesse do Irã, como o direito de os países terem seus programas nucleares pacíficos reconhecidos, inclusive enriquecimento de urânio, nos termos do TNP. Com base nesses princípios, o Irã aceitou, por escrito, termos que, até então, nunca havia aceitado nem verbalmente (PARSI, 2013; AMORIM, 2011).

Apesar do sucesso da negociação diplomática entre Irã, Turquia e Brasil e da consequente assinatura da Declaração de Teerã, os países membros do Conselho de Segurança não reconheceram a validade do acordo e a legitimidade de Brasil e Turquia em fazê-lo. Assim, mesmo o CSNU tendo sido oficialmente informado do 
fechamento do acordo, no dia 9 de junho de 2010, as sanções contidas na Resolução 1929 foram aprovadas e exigiram do Irã: a submissão de suas atividades nucleares ao monitoramento da AIEA, a suspensão de suas atividades de mísseis balísticos, a assinatura do tratado amplo de proibição de testes nucleares. Além disso, a Resolução 1929 impôs ampla gama de sanções econômicas, embargo completo de armas sobre o Irã e banimento de qualquer atividade relacionada a mísseis balísticos (OSKAN, 2011; TURAN, 2010; SOTERO, 2012; CLINTON, 2014).

No total de 15 membros do CSNU, apenas Turquia e Brasil votaram contra a Resolução 1929. O Líbano absteve-se. O voto turco de 9 de junho de 2010 contra a Resolução 1929 do CSNU contribuiu para aumentar as especulações sobre a decisão da Turquia de voltar-se contra o mundo ocidental, a favor do Oriente Médio. O Brasil e a Turquia argumentaram que o seu voto contra, na verdade, era um sim para a continuação da diplomacia como a única maneira de buscar uma solução para a questão nuclear iraniana (OSKAN, 2011; KIBAROGLU, 2012). Conforme analisa Parsi (2011) sobre a justificativa do voto contrário do Brasil e da Turquia:

For the Brazilians, after their mediation efforts, and their success in securing Tehran's signature, voting in favor of the sanctions was not really an option. "We couldn't vote in favor of the resolution, it would have been incoherent" (...) Between the Declaration and sanctions, Turkey chose Declaration. At the vote, Turkey made clear its displeasure with the swift rejection of the deal. The "Tehran Declaration" provides a new and important window of opportunity for diplomacy", Turkey ambassador to the UN said. We are deeply concerned that adoption of sanctions would negatively affect the momentum created by the Declaration and the overall diplomatic process.

De acordo com Trita Parsi (2011), uma mistura de fatores políticos, relações com outros membros permanentes do CSNU e prestígio fizeram que a diplomacia não fosse mais uma opção, pois Washington já se havia comprometido com o caminho das sanções, cujo investimento foi imenso, incluindo ações, como ligações pessoais de Obama a outros líderes mundiais e visitas de alto nível. Dessa forma, o pesado investimento no processo de sanção colaborou com que o tema se definisse em termos de prestígio. A não imposição de sanções por parte dos EUA poderia ser interpretada como vitória do Irã e fracasso e condenação por parte de Israel e de seus aliados. 
Paradoxalmente, a resistência do Irã às sanções fortaleceu o compromisso da administração de Obama com medida punitiva, como fator de prestígio.

Apesar do inicial insucesso da Declaração de Teerã, tendo em vista, logo depois, ter havido, no Conselho de Segurança da ONU, uma rodada de sanções punitivas contra o regime de Ahmadinejad, uma das vitórias contundentes da diplomacia brasileira foi a libertação da estudante francesa de ciência política, Clotilde Reiss, acusada de espionagem pelo governo iraniano. Conforme relata Parsi (2013), parte da missão de Celso Amorim em Teerã, em maio de 2010, era fazer que o governo francês e o governo iraniano voltassem a comunicar-se, conforme solicitado a Lula pelo presidente Nicolas Sarkozy. A missão, nessa questão, foi um sucesso. Por meio da mediação de Celso Amorim, os iranianos libertaram Clotilde Reiss durante a visita de Estado do Presidente Lula a Teerã (AMORIM, 2011).

O acordo trilateral entre Turquia, Brasil e Irã foi largamente divulgado em 17 de maio de 2010. Logo depois que foi alcançado, os três Estados anunciaram uma conferência de imprensa em Teerã, sobre a grande conquista. O clima era de júbilo, e uma foto de Lula, Erdogan e Ahmadinejad levantando suas mãos em um gesto vitorioso tornou-se sucesso na internet (PARSI, 2013; ABIS, 2011).

O Brasil destacou, durante as gestões da questão nuclear iraniana, sua concepção de papel nacional de mediador. Para o chanceler Celso Amorim, o Brasil e a Turquia eram os mediadores ideais para a questão nuclear iraniana, e seria mais fácil aos iranianos fazer um acordo com o Brasil do que com os Estados Unidos por dois motivos principais. Primeiro, o Brasil opunha-se a qualquer ação que visasse impedir o Irã de enriquecer urânio para fins pacíficos, pois sabia que o Irã nunca concordaria com um acordo que não the permitisse o direito de enriquecer urânio. Segundo, a política externa brasileira era contra as sanções, pois acreditava que não resolveriam o problema nuclear; ao contrário, deixariam as posições mais endurecidas, devastariam a economia iraniana e, assim como no caso do Iraque, abririam caminho para uma guerra (PARSI, 2013; CLINTON, 2014).

A Turquia, de forma paralela ao governo brasileiro, posicionou seu papel nacional para a questão nuclear iraniana, oferecendo-se como mediadora legítima. Segundo o presidente turco à época da Declaração de Teerã, o papel da Turquia era o de conduzir o Irã pelo caminho de construção de confiança em direção a uma solução diplomática para a questão. O embaixador turco na ONU, na ocasião da aprovação das sanções contra o Irã, demonstrou sua frustração com o fato de as sanções terem 
sido votadas favoravelmente, apesar dos incansáveis esforços diplomáticos turcos (KIBAROGLU, 2012).

Os EUA nunca se entusiasmaram com a Declaração de Teerã. Ao contrário, a administração de Obama garantiu o consenso da aprovação das sanções contra o Irã, com a aceitação da Rússia e da China, apenas um dia antes da chegada de Lula a Teerã. O Departamento de Estado, por exemplo, foi cético e não considerou a Declaração de Teerã como algo novo. Assim que foi firmada, os principais nomes do Departamento de Estado, como a secretária de Estado, Hillary Clinton, o subsecretário para Assuntos Políticos, Willian Burns, e o subsecretário de Estado, Jim Steinberg, opuseram-se ao acordo oficialmente (PARSI, 2013).

Segundo declarações da Casa Branca, o motivo para a rejeição da Declaração de Teerã foi uma desconfiança generalizada dos Estados Unidos em relação ao Irã. Os EUA acreditavam que a estratégia iraniana com a Declaração de Teerã firmada com Brasil e Turquia era adiar, temporariamente, a execução das sanções na crença de que, caso o frágil consenso entre os membros do CSNU acerca da imposição das sanções se desfizesse, seria impossível reconstruí-lo (TURAN, 2010; PARSI, 2013).

Aos olhos de Hillary Clinton, que se dedicava à aprovação das sanções, a mediação apareceu como uma interferência de Brasil e Turquia ou, na pior das hipóteses, uma sabotagem. De acordo com a visão da secretária de Estado do governo Obama, não havia razão para confiar nos iranianos, e havia todas as razões para acreditar que eles iriam explorar qualquer oportunidade para distrair e postergar as sanções. Segundo Clinton, qualquer concessão que os EUA fizessem aos iranianos desfaria anos de trabalho cuidadoso para construir consenso internacional em prol de sanções rígidas contra o governo iraniano de Ahmadinejad. A secretária de Estado afirmou seu ponto de vista: "There was nothing wrong with diplomacy, but the Iranians simply could not be relied upon" (CLINTON, 2014).

Apesar de admitir a emergência do Brasil como global player e o seu papelchave para as relações internacionais contemporâneas, Hillary Clinton (2014, 259:260) considerou-se frustrada com relação à iniciativa do Brasil em mediar a questão nuclear iraniana:

As Brazil economy grew, so did Lula's assertiveness in foreign policy. He envisioned Brazil becoming a major world power, and his actions led to both constructive cooperation and some frustrations. For example, in 2004, Lula sent troops to lead the UN 
peacekeeping mission in Haiti, where they did an excellent job of providing order and security under difficult conditions. On the other hand, he insisted on working with Turkey to cut a side deal with Iran on its nuclear program that did not meet the international community's requirements.

Resta saber, como proposta de trabalho para futuros pesquisadores, os motivos da descoordenação entre a incisiva afirmação de Hillary Clinton quanto à deslealdade crônica do governo iraniano e a carta de Obama, escrita em 20 de abril de 2010 e publicada pelo governo brasileiro, que solicita ajuda diplomática do Brasil na negociação da questão nuclear do Irã. Ou, então, cabe descobrir se a carta de Obama era apenas mero instrumento de retórica, para galantear a contraparte brasileira.

No que diz respeito à percepção de outros países do P5+1, com relação aos acordos negociados em Teerã, entre Brasil, Irã e Turquia, observou-se que esses países rejeitaram-nos em sua totalidade e declararam, de forma assertiva, que o acordo não afetaria o processo de negociação das sanções no CSNU. A chancelaria britânica, por exemplo, interpretou a Declaração de Teerã como uma distração. Os chineses e os russos fizeram "jogo duplo": de um lado, parabenizaram a mediação conquistada por Lula e Erdogan; de outro, não mostraram nenhuma inclinação em retirar seu apoio para a resolução, contendo sanções ou, pelo menos, rever sua decisão de apoio às sanções a Teerã (KIBAROGLU, 2012; PARSI, 2013; CLINTON, 2014).

O significado da Declaração de Teerã vai além do acordo de troca de combustível nuclear entre Brasil, Turquia e Irã, em 17 de maio de 2010. O processo de negociação em questão pode ser considerado como um marco da política internacional contemporânea com implicações em conceitos e arranjos do sistema internacional, como, por exemplo, a ressignificação do conceito de potência média, de potência emergente, a disputa entre força e diplomacia nas relações internacionais e, por fim, as consequências para a reforma da governança global (OSKAN, 2011; KIBAROGLU, 2012).

No que tange às potências médias e sua atuação no contexto internacional, pode-se afirmar que a Declaração de Teerã deu novo significado ao futuro do ativismo dos Estados médios em nível local, regional e global. Além disso, o acordo mostrou que a temática de segurança nuclear não é mais apenas para as grandes potências; ao contrário, as potências médias querem ter suas vozes ouvidas e, com o acordado em Teerã, mostraram que têm poder para isso. Segundo Werz (2010), o 
Presidente Lula, por exemplo, utilizou-se da crise nuclear iraniana para dar mais um passo em criar novo paradigma alternativo às potências médias.

$\mathrm{O}$ conflito entre as potências médias e as grandes potências instaura-se quando, segundo Parsi (2012), as médias tentam assumir um papel ativo nas questões internacionais, e as grandes opõem resistência ao enfraquecimento do seu domínio. Para Trita Parsi (2012), o fato de o Brasil e a Turquia adotarem perfil mais assertivo em suas políticas externas gerou essa modalidade de conflitos.

Por outro ângulo, o acordo pode ser interpretado como prova da dificuldade dos países emergentes para fazer-se reconhecer como atores políticos importantes no contexto internacional, demonstrando grande divergência de método e opinião na resolução de questões de segurança entre as potências estabelecidas e as emergentes. Segundo Élodie Brun (2011), no nível regional, o trampolim iraniano teve como objetivo consolidar o reconhecimento do Brasil como gigante sul-americano.

Ao analisar o jogo de poder entre força e diplomacia, no que diz respeito à questão nuclear iraniana, pode-se interpretar que a Declaração de Teerã firmou os iranianos não concederem qualquer poder a qualquer país que quisesse conversar por meio da força bruta. O Brasil e a Turquia, nesse sentido, não foram à mesa de negociações com o Irã conversar sob os auspícios da hierarquia do sistema internacional existente; ao contrário, conversaram com sua contraparte como iguais (OSKAN, 2011).

Segundo explica Parsi (2013), enquanto Washington trabalhava em conseguir que todos os membros do CSNU votassem favoravelmente, em nova rodada de sanções contra o Irã, o Brasil e a Turquia, ao mesmo tempo, perseguiam o ideal de retorno à diplomacia. Para esses dois países médios, a luta em prol da diplomacia era, também, contra as sanções (PARSI, 2013). Em entrevista a Parsi (2013), sobre os resultados do acordo de Teerã, Lula respondeu gentilmente e censurou as potências Ocidentais, por não serem sérias o suficiente, ao tratar da diplomacia.

Os acontecimentos recentes envolvendo o acordo nuclear entre Irã, Turquia e Brasil fizeram que o Brasil, pela primeira vez, individualmente, tivesse presença política e diplomática mais visível naquela complexa e conturbada região (AZAMBUJA, 2010). Em última instância, pode-se afirmar que o acordo entre Brasil e Turquia abriu espaço para o debate acerca da reforma da governança global. As ineficiências das instituições internacionais e a crise geral de legitimidade que o contexto após a Guerra Fria enfrentou foram levantadas ao longo das negociações. 
Dessa forma, apesar de, concretamente, ter tido poucos efeitos, a Declaração de Teerã ilustra a vontade do Brasil em afirmar-se como ator global, privilegiando o multilateralismo e a solidariedade entre os países do Sul, constituindo, assim, novas alianças que contestam as relações geopolíticas tradicionais. As ambições da política externa brasileira de que o país se converta em ator global e que consiga assento permanente no Conselho de Segurança da ONU são evidenciadas pelo fato de o Brasil estar presente às grandes questões mundiais de segurança coletiva, nas quais a questão nuclear iraniana é central (OSKAN, 2011; ABIS, 2011; MUXAGATO, 2010).

\subsection{Conclusão}

A concepção de papel nacional de mediador, projetada pela PEB do governo Lula durante as tentativas de mediação da questão palestina e da questão iraniana, foi, hierarquicamente, a mais importante desempenhada pela política externa brasileira no Oriente Médio, entre os anos de 2003 e de 2010. A priorização de mediador de conflitos é evidenciada tanto pela intensa midiatização das mediações quanto em razão dos princípios que o Brasil passou à comunidade internacional ao longo das negociações, tais como: solução diplomática das controvérsias, pacifismo, respeito às normas internacionais, necessidade de coexistência de dois Estados e direito iraniano ao enriquecimento nuclear para fins pacíficos. Por meio da descrição do posicionamento da diplomacia brasileira com relação à questão palestina e ao processo de negociação ocorrido em Teerã, que culminou com a assinatura do acordo, em maio de 2010, a PEB instrumentalizou sua concepção de papel nacional (national role conception) primária e mais importante no Oriente Médio, para reafirmar seu objetivo e seu desejo de reformar as instituições da governança global e de reconfigurar o espaço das potências médias no sistema internacional. 


\section{CONSIDERAÇÕES FINAIS}

Este trabalho teve como objetivo geral entender de quais maneiras a política externa brasileira dos dois mandatos presidenciais do governo Lula projetou seu papel na região do Oriente Médio. Especificamente, foi também objeto investigatório desta dissertação compreender os motivos pelos quais o Brasil se aproximou, de forma tão intensa e assertiva, dos países da região do Oriente Médio, entre 2003 e 2010.

Por meio de pesquisa extensiva em fontes primárias e secundárias, sobre o tema, chegou-se à conclusão de que a PEB do governo Lula se projetou na região do Oriente Médio, por meio de cinco principais papéis, hierarquicamente arranjados em sua força e em sua importância. Em ordem decrescente, são eles: ponte entre os povos, países e regiões; defensor da paz e dos direitos humanos; agente promotor de assistência humanitária internacional; criador de novos arranjos políticos, diplomáticos e econômicos alternativos ao status quo; mediador de conflitos ou promotor de consensos.

O papel de ponte entre os povos foi classificado por esta pesquisa como "prépapel”, pois essa função foi usada pelos formuladores de política externa brasileira e por seus executores como um recurso de retórica, para instrumentalizar os discursos do Brasil em relação aos países do Oriente Médio. Apresentando-se como "ponte entre povos, países ou nações", o Estado brasileiro valeu-se de argumentos psicológicos, históricos e imigratórios acerca da herança árabe à cultura brasileira, com a finalidade de criar empatia com seus interlocutores. Assim, uma vez conquistada a atenção e a identificação com seu interlocutor, a PEB projeta novo papel, dependendo do objetivo da viagem, da visita ou do acordo com o Oriente Médio. Dessa forma, os quatro outros papéis identificados neste trabalho são normalmente precedidos da utilização da concepção nacional dos formuladores brasileiros do Brasil como ponte entre os povos árabes e o mundo Ocidental.

Classificaram-se três outros papéis (defensor da paz e dos direitos humanos, promotor de assistência humanitária internacional e promotor de novos arranjos políticos, diplomáticos e econômicos alternativos ao status quo) como secundários. $\mathrm{O}$ primeiro deles, de caráter teórico, foi utilizado como instrumental de retórica, ao 
reafirmar a defesa do Brasil pelos princípios da paz e da defesa dos direitos humanos, em especial, no que diz respeito às notas de posicionamento do Brasil e aos discursos das autoridades brasileiras, em relação ao conflito entre Israel e Palestina e a outros conflitos contemporâneos no Oriente Médio.

Evidências empíricas da expressão prática e da fundamentação do Brasil como defensor da paz e dos direitos humanos foram encontradas em outro papel projetado pelo Brasil: o de agente promotor de assistência humanitária internacional. Durante o governo Lula, foi criada, no âmbito do Ministério das Relações Exteriores, coordenação específica $^{147}$, além de alínea orçamentária própria, destinada à prestação de ajuda humanitária pelo governo brasileiro. Em consonância com os princípios da política externa do Partido dos Trabalhadores de defesa do direito dos povos palestinos e da criação de um Estado palestino, grande parte da ajuda humanitária prestada pelo governo brasileiro ao longo do governo Lula foi destinada à Palestina, totalizando US\$29.900.000, voltados a programas de cooperação, compra de medicamentos, alimentos e ajuda emergencial para reconstrução de escola e campos de refugiados.

O terceiro e não menos importante papel projetado pela PEB do governo Lula para a região do Oriente Médio foi o de criador de novos arranjos políticos, diplomáticos e econômicos alternativos ao status quo. Esse é o instrumento pelo qual se verifica uma das características da PEB elencadas no primeiro capítulo, a cooperação sul-sul, e é uma das estratégias metodológicas de formação de novas coalizões e parcerias para o alcance dos objetivos da PEB. Nesse contexto, durante o primeiro mandato do governo Lula, em 2003, foi criada a Cúpula América do Sul Países Árabes (ASPA), cujo objetivo foi a elaboração de um fórum de diálogo que reunisse países da América do Sul e do Oriente Médio, para contrabalançar o peso das potências tradicionais. Além disso, novos arranjos comerciais foram firmados ao longo do governo Lula, entre o MERCOSUL e os países árabes ${ }^{148}$, evidenciando a disposição da PEB em manter arranjos econômicos alternativos ao status quo.

O último e mais importante papel concebido pela PEB para o Oriente Médio foi o de mediador de conflitos ou construtor de consensos, por meio do qual o Brasil conseguiu, finalmente, exercer a função de global player na high politics de

\footnotetext{
${ }^{147}$ Coordenação-Geral de Ações Internacionais de Combate à Fome e Assistência Humanitária (CGFOME)

${ }^{148}$ Foram assinados acordos com seis países do Oriente Médio (Israel, Palestina, Egito, Jordânia, Síria e Marrocos), além do Conselho de Cooperação do Golfo (CCG).
} 
segurança internacional do Oriente Médio, posicionando-se em dois dos grandes temas da política internacional contemporânea da região: a questão palestina e a questão nuclear iraniana. Como mediador, notadamente, o governo Lula conseguiu visibilidade internacional de suas ações e posicionamentos, adquirindo tanto reconhecimento quanto rejeição das contrapartes do sistema internacional contemporâneo de seu novo posicionamento nos jogos de poder da região.

O pressuposto central do trabalho é o de que a PEB instrumentalizou todos os cinco papéis projetados para o Oriente Médio durante o governo Lula, em prol da consecução do seu "substrato normativo" de política externa, ou seja, buscando um dos seus objetivos centrais: o de reforma da governança global e, mais especificamente, das instituições multilaterais de segurança como o CSNU (VARGAS, 2008; COELHO, 2014). De acordo com Vargas (2008:2), o substrato normativo em política exterior:

Refere-se a um conjunto de normas de comportamento do Brasil frente às realidades internacionais que informam as decisões dos formuladores da política exterior. O substrato normativo da política externa brasileira é um produto de instituições políticas, pensamento individual e cultura nacional, entre outros elementos.

A hipótese central do trabalho vai de encontro à posição do ministro Celso Amorim, explicitada durante aula-palestra, no Instituto Rio Branco, no dia 25 de outubro de 2010, sobre "O Brasil e a reforma do Conselho de Segurança da ONU" (AMORIM, 2011:437):

\footnotetext{
Quando o Brasil começou a se empenhar para que houvesse uma aproximação entre a América do Sul e os países árabes - e de modo geral passou a se interessar mais pelo Oriente Médio - foi visto como um país que mantinha o objetivo de chegar ao Conselho de Segurança. Quero dizer que, sinceramente, a aproximação não teve essa motivação (grifo nosso).
}

Conforme evidenciado ao longo da dissertação, na medida em que a PEB projetava um de seus papéis para o Oriente Médio, os formuladores encontravam uma maneira de infiltrar, em seus discursos, entrevistas após reuniões multilaterais ou coletivas de imprensa durante visitas bilaterais, o objetivo de reforma da governança global, das instituições multilaterais e da não conformidade do CSNU ao sistema interacional de poder contemporâneo. Tentou-se, ao longo do trabalho, evidenciar 
esses trechos de discursos e essa estratégia de inserção internacional e consecução de objetivo de política externa do Brasil.

Ademais, nos casos de mediação de conflitos nos quais o Brasil atuou, como na questão palestina e na questão nuclear iraniana, que culminou com a assinatura da Declaração de Teerã entre Brasil, Turquia e Irã, as contrapartes brasileiras, ou seja, outros atores internacionais envolvidos nas high politics de segurança do Oriente Médio, como a chefe do Departamento de Estado à época, Hillary Clinton (2014:416446), reconheceram e afirmaram o objetivo do Brasil de instrumentalizar a mediação da questão nuclear iraniana em prol de seu objetivo de exercer maior influência nas instâncias multilaterais da governança global e atuar no sentido de reformá-las.

\footnotetext{
Ever since October 2009 agreement collapsed, Turkey and Brazil had been making noises about revisiting it. Both countries held rotating seats of the UNSC and were eager to exercise influence on the world stage. They were prime examples of the "emerging powers" whose rapid economic growth was fueling big ambitions for regional and global influence. They also happened to have two confident leaders as LuizInácio Lula da Silva and RecepErdogan, both of whom considered themselves to be men of action able to bend history to their will (grifo nosso).
}

Em recente entrevista sobre o assunto, o atual subchefe da Missão do Brasil junto à ONU em Nova Iorque, no governo Dilma Rousseff, afirmou que "A vaga permanente segue sendo um de nossos pleitos prioritários, mas o assunto não é tratado no dia a dia, mas, sim, de forma subterrânea". Resta saber, como objeto de futuras pesquisas, o motivo pelo qual a diplomacia brasileira, em especial, os formuladores de política externa brasileira, não argumente seu pleito de reforma da governança global de forma mais objetiva, nas instâncias multilaterais ou não instrumentalize, de maneira clara, suas ações e seus papéis internacionais em prol dessa intenção, tendo em vista que esse é um pleito que faz parte do "substrato normativo" tradicional da política externa brasileira (VARGAS, 2008:2). 


\section{REFERÊNCIAS}

- Artigos

ABIS, Sébastien. Brésil: une présense qui se confirme en Méditerranée. Revue trimestrielle pour le dialogue entre le Magreb, l'Espagne et l'Europe. Paris: p. 56$58,2011$.

ABIS, Sébastien; NARDONE, Jessica. Le Brésil, futurefermedu monde arabe? Futuribles Revue. n. 356, octobre, 2009.

AGGESTAM, Lisbeth. Role Conceptions and the Politics of Identity in Foreign Policy. ARENA Working Papers. Stockholm: 1998/1999.

ALMEIDA, Paulo Roberto de. A política internacional do Partido dos Trabalhadores: da fundação à diplomacia do governo Lula. Revista de Sociologia e Política, Curitiba, 20, p. 87-102, junho de 2003.

- Uma política externa engajada: a diplomacia do governo Lula. Revista Brasileira de Política Internacional, 47 (1): 162-184, 2004.

—. Uma nova "arquitetura" diplomática? Interpretações divergentes sobre a política externa do governo Lula (2003-2006). Revista Brasileira de Política Internacional 49 (1): 95-116, 2005.

- A diplomacia da era Lula: balanço e avaliação. Política Externa. São Paulo: v. 19, n. 2, setembro, outubro e novembro de 2010.

AMORIM, Celso. A Política Externa Brasileira no governo do Presidente Lula (20032010): uma visão geral. Revista Brasileira de Política Internacional, 53 (special edition): 214-240 [2010]. 
AZAMBUJA, Marcos Castrioto. Irã, Turquia e Brasil: lições do passado e riscos do presente. Revista Política Externa. São Paulo, v. 19, n.2, p. 123-130, set./out./nov. 2010.

BERNAL-MEZA, Raúl. Pensamento Internacional na era Lula. Revista Brasileira de Política Internacional, 53 (special edition): 193-213 [2010].

BOITO JR., Armando \& BERRINGER, Tatiana. Brasil: classes sociais, neodesenvolvimentismo e política externa nos governos Lula e Dilma. Revista de Sociologia e Política, Curitiba, v. 21, N 47: 31-38, setembro 2013.

BREDA DOS SANTOS, Norma. A política externa do governo Lula com relação ao conflito Israel-Palestina. Revista História. São Paulo, v. 33, n.2, p.189-216, julho/dezembro 2014.

BRUN, Élodie. O Irã na América Latina. Revista Política Externa. São Paulo, v. 19, n. 4, p. 79-96, março/abril/maio 2011.

CERVO, Amado Luiz. Os objetivos da política exterior de Lula. Revista Meridiano 47, junho de 2004, p. 2-5.

A ascensão do Brasil no cenário internacional: o Brasil e o mundo. Revista Brasileira de Política Internacional 53 (special edition): 7-32 [2010].

DAVUTOGLU, Ahmet. A política externa da Turquia em um ambiente internacional de rápida evolução. Revista Política Externa. São Paulo, v. 20, n. 4, p. 67-73, março/abril/maio de 2012 .

HAFFNER, Jacqueline; HOLAND, Carla. Relações econômicas entre o Brasil e o Oriente Médio no governo Lula. Revista Ciências \& Letras. Porto Alegre, n. 51, p. 135-156, janeiro-junho de 2012.

HERMANN, Charles. Changing course: when governments choose to redirect foreign policy. International Studies Quartely. Vol. 34, No 1, 1990, p. 3-21. 
HIRST, Monica; LIMA, Maria Regina Soares; PINHEIRO, Letícia. A política externa brasileira em tempos de novos horizontes e desafios. Revista Nueva Sociedad. Dezembro de 2010.

HOLSTI, Kalevi Jaakko. National Role Conceptions in the Study of Foreign Policy. International Studies Quartely, Vol. 14, No 3, p. 233-309, setembro, 1970.

JAKOBSEN, Kjeld Aagaard. Desventuras de alguns críticos da política externa do governo Lula. Lua Nova, São Paulo, 89: 275-295, 2013.

KIBAROGLU, Mustafa. Uma perspectiva turca sobre a iniciativa nuclear BrasilTurquia em relação ao Irã. Revista Política Externa. São Paulo, v. 20, n.3, p. 61-68, dezembro/janeiro/ fevereiro, 2011-2012.

LESSA, Antônio Carlos. Parcerias estratégicas do Brasil: um balanço da era Lula (2003-2010). Revista Brasileira de Política Internacional 53 (special edition): 115-131 [2010].

LIMA, Maria Regina Soares. A política externa brasileira e os desafios da cooperação Sul-Sul. Revista Brasileira de Política Internacional 48 (I): 24-59 [2005].

MAIHOLD, Gunther. Demasiado Mundo? Lula, Brasil y Oriente Médio. Real Instituto Elcano (ARI). 2010.

MANZUR, Tânia Maria Pechir Gomes. La Cumbre Aspa y los Países Árabes: reflejos de la crisis actual, desde una perspectiva brasileña. Mural Internacional, Rio de Janeiro, ano II, nº 2, dezembro de 2011.

MUXAGATO, Bruno. Les relations Brésil-Iran et la question du nucleaire. Le Chronique des Amériques. Volume 2, p. 1-9, abril, 2010. 
OLIVEIRA, Marcelo Fernandes. Alianças e coalizões do governo Lula: o IBAS e o G-20. Revista Brasileira de Política Internacional, 8(2): 55-69, 2005.

OZKAN, Mehmet. Turkey-Brazil involvement in Iranian Nuclear Issue: what is the big deal? Strategic Analysis, v. 35, n. 1, p. 26-30, janeiro de 2011.

PARSI, Trita. A Declaração de Teerã e o futuro da mediação turco-brasileira. Revista Política Externa, São Paulo, v. 20, n.3, p. 69-74, dezembro/janeiro/fevereiro, 2011212.

RICUPERO, Rubens. À sombra de Charles de Gaulle: uma diplomacia carismática e intransferível. Novos Estudos, 87, julho de 2010.

SANTANA, Carlos Ribeiro. A política externa do Governo Lula: um breve balanço. Revista Meridiano 47, No 71-72, junho-julho 2006.

SARAIVA, José Flávio Sombra. Dois anos da Política Externa de Lula. Revista Meridiano 47, $\mathrm{N}^{\circ} 52$ e 53, novembro/dezembro 2004.

SARAIVA, Miriam Gomes. Política externa brasileira para a América do Sul durante o governo Lula: entre a América do Sul e MERCOSUL. Revista Brasileira de Política Internacional, 53 (special edition): 151-168 [2010].

- Continuidade e mudança na política externa: as especificidades do comportamento brasileiro de 2003 a 2010. Relações Internacionais, março 2013 (p. 63-78).

SOTERO, Paulo. Uma reflexão sobre a frustrada iniciativa Brasil-Turquia para superar o impasse nuclear entre o Irã e a comunidade internacional. Revista Política Externa, v. 20, n.3, p. 75-79, dezembro/janeiro/fevereiro, 2011-2012.

—. Lula's Tehran Misadventure. Revista Foreign Policy. Maio de 2010. Disponível em <http://foreignpolicy.com/2010/05/11/lulas-tehran-misadventure $>$. Acesso em 22 de dezembro de 2014. 
SOUTO MAIOR, Luiz Augusto. Desafios de uma política externa assertiva. Revista Brasileira de Política Internacional, Brasília, 46, p. 12-34, 2003.

THIES, Cameron. Role Theory and Foreign Policy. International Studies Association. Iowa City, USA: Maio, 2009.

TURAN, Ilter. Estranhos companheiros ou novos aliados: a aventura nuclear do Brasil, da Turquia e do Irã. Revista Política Externa. São Paulo, v. 19, n.2, p. 123130, set./out./nov. de 2010.

VIGEVANI, Tullo; CEPALUNI, Gabriel. A Política Externa de Lula da Silva: a estratégia da autonomia pela diversificação. Revista Contexto Internacional, Rio de Janeiro, vol. 29, nº 2, julho/ dezembro de 2007, p. 273-335.

WERZ, Michael; CHEN, Winny. Brazil and the Middle East. Revista American Progress. Junho de 2010 . Disponível em <https://www.americanprogress.org/issues/security/news/2010/06/17/7866/brazilin-the-middle-east/>. Acesso em 20 de dezembro de 2014.

\section{- Dissertações}

COELHO, Natália Bandeira Ramos. Em busca de prestígio internacional? A política externa brasileira para obtenção de assentos permanentes na Liga das Nações e na ONU (1921-2010). Dissertação de Mestrado em Relações Internacionais. Instituto de Relações Internacionais, Universidade de Brasília, 2014.

VARGAS, João Augusto Costa. Campanha permanente: a construção do substrato normativo da busca do Brasil por uma reforma do Conselho de Segurança das Nações Unidas. Dissertação de Mestrado em Relações Internacionais. Instituto de Relações Internacionais, Universidade de Brasília, 2008. 


\section{- Entrevistas}

RONDÓ, Milton. A política brasileira de cooperação humanitária. NBR entrevista. Entrevista concedida à Karla Walthier em 17 de fevereiro de 2013. Disponível em $<$ https://www.youtube.com/watch?v=5CkYPRerTrs $>$. Acesso em 18 de agosto de 2014.

\section{- Fontes primárias}

FUNAG. Conferência Nacional de Política Externa e Política Internacional - II CNPEPI: (2: Rio de Janeiro: 2007: o Brasil no mundo que vem aí. Brasília: Fundação Alexandre de Gusmão, 2008.

—. Discursos selecionados do Presidente Luiz Inácio Lula da Silva. Brasília: Fundação Alexandre de Gusmão, 2008.

MINISTÉRIO DAS RELAÇÕES EXTERIORES. Repertório de política externa: posições do Brasil. Brasília: Fundação Alexandre de Gusmão, 2007.

—. Repertório de política externa: posições do Brasil (2008-2009). Elaborado por Thomaz Mayer Alexandre Napoleão. Coordenado por Hermano Telles Ribeiro. Brasília, FUNAG, 2010.

Resenha de Política Exterior do Brasil. Brasília: Ministério das Relações Exteriores. Número $92,1^{\circ}$ semestre de 2003.

—. Brasília: Ministério das Relações Exteriores. ํ 93, $2^{\circ}$ semestre de 2003.

—. Brasília: Ministério das Relações Exteriores. ํ 94, $1^{\circ}$ semestre de 2004. . Brasília: Ministério das Relações Exteriores. N 95, 2º semestre de 2004. 
—. Brasília: Ministério das Relações Exteriores. ํ 96, $1^{\circ}$ semestre de 2005.

—. Brasília: Ministério das Relações Exteriores. № 98, $1^{\circ}$ semestre de 2006.

—. Brasília: Ministério das Relações Exteriores. № 99, $2^{\circ}$ semestre de 2006.

—. Brasília: Ministério das Relações Exteriores. № 100, $1^{\circ}$ semestre de 2007.

—. Brasília: Ministério das Relações Exteriores. № 101, 2º semestre de 2007.

—. Brasília: Ministério das Relações Exteriores. N 102, $1^{\text {o }}$ semestre de 2008.

—. Brasília: Ministério das Relações Exteriores. № 103, $2^{\circ}$ semestre de 2008.

—. Brasília: Ministério das Relações Exteriores. № 104, ${ }^{\circ}$ semestre de 2009.

—. Brasília: Ministério das Relações Exteriores. № 105, 2º semestre de 2009.

—. Brasília: Ministério das Relações Exteriores. № 106, $1^{\circ}$ semestre de 2010.

—. Brasília: Ministério das Relações Exteriores. N $^{\circ} 107,2^{\circ}$ semestre de 2010.

SELA. Sistema Econômico Latino-Americano e do Caribe. Las relaciones de America Latina y el Caribe con el Medio Oriente: situación actual y áreas de oportunidade. Secretaria Permanente del SELA. Caracas, 2011.

Sumário Ostensivo Itamaraty, República Islâmica do Islã. Divisão de Ásia Central, Ministério das Relações Exteriores.

\section{- Livros e capítulos de livros}

ALBUQUERQUE, José Guilhon (org.). Sessenta anos de política externa brasileira (1930-1990): o desafio geoestratégico. São Paulo: Annablume, 2000. 
ALTEMANI, Henrique; LESSA, Antonio Carlos. Relações Internacionais do Brasil: temas e agendas. Vol. 2. São Paulo: Saraiva, 2006.

AMORIM, Celso. Conversas com jovens diplomatas. São Paulo: Benvirá, 2011.

BAER, Werner; LOVE, Joseph. Brazil under Lula: Economy, Politics, and Society under the Worker-President. New York: Palgrave-Macmilian, 2009.

BARBOZA, Mário Gibson. Na diplomacia, o traço todo da vida. Rio de Janeiro: Record, 1992.

BURGES, Sean. Brazilian Foreign Policy after the Cold War. Gainesville: University Press of Florida, 2009.

CARDOSO, Fernando Henrique. A arte da política: a história que vivi. 6. ed. Rio de Janeiro: Civilização Brasileira, 2012.

CARRILHO, Arnaldo. O Brasil e a Questão palestina: ambiguidades, equidistâncias e engajamento. In: II Conferência Nacional de Política Externa e Política Internacional: o Brasil no mundo que vem aí. Brasília: Fundação Alexandre de Gusmão, 2008.

CARVAlHO, José Murilo de. D. Pedro II. São Paulo: Companhia das Letras, 2007.

CERVO, Amado Luiz. Inserção internacional: formação dos conceitos brasileiros. São Paulo: Saraiva, 2008.

CERVO, Amado Luiz; BUENO, Clodoaldo. História da Politica Exterior do Brasil. 4. ed. Brasília: Universidade de Brasília, 2012.

CLINTON, Hillary Rodham. Hard Choices. London: Simon \& Schuster UK Ltd., 2014. 
FARAH, Paulo. O Brasil e o Oriente Médio: acerca das políticas externas e da consolidação de relações privilegiadas. In: II Conferência Nacional de Política Externa e Política Internacional: o Brasil no mundo que vem aí. Brasília: Fundação Alexandre de Gusmão, 2008.

FRANK, Robert. Pour l'histoire des relations internationales. Paris: Presses Universitaires de France, 2012.

GARCIA, Eugênio Vargas. Cronologia das Relações Internacionais do Brasil. 2. ed. Rio de Janeiro: Contraponto, 2005.

HARNISCH, Sebastian. Role Theory: operationalization of key concepts. In: HARNISCH, Sebastian; FRANK, Cornelia \& MAULL, Hanns (Org.). Role Theory in international relations: approaches and analyses. London: Routledge, 2012.

HARNISCH, Sebastian; FRANK, Cornelia\& MAULL, Hanns (Org.). Role Theory in international relations: approaches and analyses. London: Routledge, 2012.

LE PRESTE, Philippe. Role quests in the post-cold war era: foreign policies in transition. Québec: McGill-Queen's University Press, 1997.

PARSI, Trita. A Single Roll of the Dice. New Haven: Yale University Press, 2013.

PINTO, Vânia Carvalho. Brasil e países árabes: uma parceria estratégica, inovadora e ousada? In: LESSA, Antônio Carlos; OLIVEIRA Henrique Altemani de (org.) Parcerias estratégicas do Brasil: a dimensão multilateral e as parcerias emergentes. Belo Horizonte: Editora Fino Traço, 2013.

ROETT, Riordan. The New Brazil. Washington: Brookings Institution Press, 2011.

ROHTER, Larry. Brazil on the rise: the story of a country transformed. New York: Palgrave Macmillan, 2012. 
ROSA, Luciano Ozorio. O Brasil e o Oriente Médio (1930-1990). In: Sessenta anos de política externa brasileira (1930-1990): o desafio geoestratégico. v. 3. São Paulo: Annablume/NUPRI/USP, 2000.

SMITH, Steve; HADFIELD, Amelia; DUNNE, Tim. Foreign Policy: theories, actors and cases. 2. ed. Oxford: Oxford University Press: 2012.

SPEKTOR, Matias (org.) Azeredo da Silveira: um depoimento. Rio de Janeiro: FGV, 2010.

TICKNER, Arlene. Rising Brazil and South America. In: SMITH, Steve; HADFIELD, Amelia; DUNNE, Tim. Foreign Policy: theories, actors and cases. 2. ed. Oxford: Oxford University Press: 2012.

\section{- Notícias}

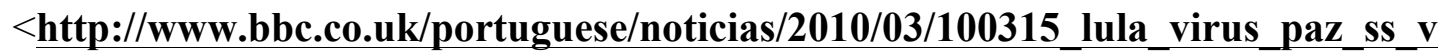
dm.shtml>. Acesso em 12 de agosto de 2014.

COUTINHO, Marcelo. A América do Sul na PEB. Valor Econômico. 17 ago. 2009.

LAFER, Celso. Partidarização da política externa. O Estado de São Paulo, 20 de dezembro de 2009. < http://www.estadao.com.br/noticias/impresso,partidarizacaoda-politica-externa,484941,0.htm>. Acesso em 18 de março de 2014.

\section{- Relatórios}

COOPERAÇÃO HUMANITÁRIA INTERNACIONAL. Coordenação-Geral de Ações Internacionais de Combate à Fome (CGFOME). Ministério das Relações Exteriores. Balanço 2006-2010. Brasília, 2011. 
O governo Lula segundo seus ministros. Vol.4. Brasília: Presidência da República, Secretaria de Assuntos Estratégicos - SAE, 2010.

\section{- Sites}

Divisão de Atos Internacionais (DAI) do Ministério das Relações Exteriores $<$ http://dai-mre.serpro.gov.br/pesquisa_ato_mul $>$. Acesso em 5 de setembro de 2014.

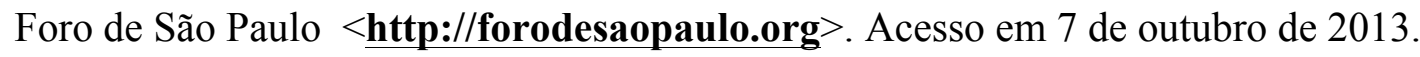

Fotos Alan Marques $<$ http://www.alanmarques.com.br/nuncaantes/ $>$. Acesso em 3 de novembro de 2014 .

Instituto Lula <http://www.institutolula.org/com-nova-embaixada-no-malawipresenca-diplomatica-do-brasil-na-africa-estende-se-para-38-paises $>$. Acesso em 25 de outubro de 2014.

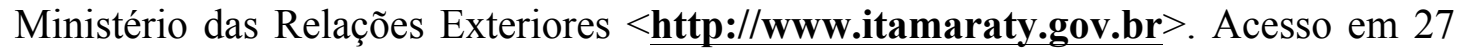
de agosto de 2014.

Ministério do Desenvolvimento, Indústria e Comércio Exterior $<$ http://www.mdic.gov.br/sitio/interna/interna.php?area=5\&menu=2716 $>$.

Acesso em 5 de setembro de 2014. 


\section{ANEXOS}

ANEXO 1: Linha do tempo histórica das relações entre o Brasil e o Oriente Médio: de D. Pedro II a Fernando Henrique Cardoso

1871

- D. Pedro II viaja à Palestina e ao Egito, em caráter particular.

1947

- O brasileiro Oswaldo Aranha preside a Assembleia Geral das Nações Unidas quando se aprovou o Plano de Partilha da Palestina.

- Com o apoio de Oswaldo Aranha, presidente da II AGNU, a ONU aprova plano para a divisão da Palestina, prevendo a criação de um Estado judeu e de um Estado palestino, além do status especial para Jerusalém.

1949

- O Estado de Israel é admitido na ONU, com o voto favorável do Brasil.

1951

- Cria-se a legação do Brasil junto ao Estado de Israel, em Tel Aviv.

1956

- A crise do canal de Suez leva à primeira participação direta do Brasil nos acontecimentos do Oriente Médio.

1973

- Mário Gibson Barboza é o primeiro chanceler brasileiro a visitar o Egito (de 28 a 31 de janeiro) e Israel $^{149}$ (de 4 a 8 de fevereiro), buscando maior

${ }^{149}$ Acordos firmados com Israel em razão da visita do chanceler Mário Gibson Barboza:

1. Programa de cooperação Brasil-Israel para a irrigação e valorização de áreas atingidas pela seca. 
aproximação com os países do Oriente Médio, de acordo com o conceito de equidistância do Brasil em relação ao conflito árabe-israelense.

- A guerra de 1973 não modifica a posição de equidistância do Brasil diante do conflito árabe-israelense.

- Os esforços do Brasil para penetrar no Oriente Médio foram tardios e determinados, sobretudo, pela elevação dos preços do petróleo, a partir de 1973.

- Segundo a orientação da $\mathrm{PEB}$, há rigorosa equidistância entre as partes do conflito árabe-israelense.

- Inicia-se a Guerra de Yom Kippur.

1974

- Antonio Francisco Azeredo da Silveira é nomeado chanceler do governo Geisel, que adota política externa definida como pragmatismo responsável e ecumênico com ênfase na promoção de interesses comerciais e na abertura de novos mercados.

- Políticas específicas são definidas para o Oriente Médio, a partir da gestão de Azeredo da Silveira.

- Em resolução apoiada pelo Brasil, a XXIX AGNU reconhece a OLP como único representante do povo palestino.

1975

- A posição do Itamaraty redefine-se em relação aos conflitos no Oriente Médio e em relação à Palestina.

- Na XXX AGNU, o chefe da delegação brasileira vota a favor de resolução segundo a qual o povo palestino tem direito à autodeterminação e à soberania, cujo exercício é condição da paz para a região, devendo as tropas israelenses retirar-se de todos os territórios ocupados pela força.

- O Brasil vota a favor de Resolução da ONU proposta pelos países árabe que considera o sionismo uma forma de racismo e discriminação racial. O governo brasileiro estabelece distinção entre o apoio ao governo de Israel e o sionismo.

2. Cooperação entre o Centro de Estudos de Colonização Rural e Urbana de Rehovot, o Banco do Nordeste do Brasil e a Universidade Federal do Ceará.

3. Promoção de cooperação no campo da pesquisa científica e desenvolvimento tecnológico. 
O governo dos EUA manifesta desaprovação ao voto brasileiro. Kissinger manda nota impertinente ao governo brasileiro contra essa votação na Comissão, pendido que modificássemos o voto.

- O voto antissionista é ressentido por Tel Aviv e pela comunidade judaica internacional. O posicionamento em favor dos direitos do povo palestino não favorece o diálogo bilateral Brasil-Israel.

- Para Geisel, o sionismo é um preconceito racial. Não conformado com o voto brasileiro, Kissinger manda nota impertinente ao governo brasileiro contra essa votação na Comissão, pedindo que o governo brasileiro modificasse o voto. O governo brasileiro, por sua vez, decide não modificar o voto em plenário e vota novamente a favor.

- Na AGNU, a política brasileira passa a incorporar 4 pontos principais em relação ao Oriente Médio:

i. Retirada completa das forças de ocupação de todos os territórios árabes.

ii. Reconhecimento do direito do povo palestino à autodeterminação.

iii. Participação da OLP, representante legítima do povo palestino nas negociações de paz.

iv. Reconhecimento do direito de todos os Estados da região de existir em paz, nas fronteiras reconhecidas.

1980

- O Brasil permanece neutro no conflito Irã-Iraque (1980-1988). O governo brasileiro, entretanto, não despreza a oportunidade de suprir o Iraque com produtos manufaturados, alimentos e armas.

1986

- As relações com Tel Aviv indicam reaquecimento das conversações em Brasília, com o vice-ministro dos Negócios Estrangeiros de Israel e pela visita de Shimon Peres ao Brasil, em 1987. 
1988

- O Brasil reconhece a Declaração de independência da Palestina, mas não o Estado palestino proclamado em Argel, em 15 de novembro de 1988.

1993

- Abertura da representação da Delegação Especial da Palestina no Brasil. 
ANEXO 2: Declaração conjunta de Irã, Turquia e Brasil - 17 de maio de 2010

Tendo-se reunido em Teerã em 17 de maio, os mandatários abaixo assinados acordaram a seguinte Declaração:

1. Reafirmamos nosso compromisso com o Tratado de Não Proliferação de Armas Nucleares (TNP) e, de acordo com os artigos relevantes do TNP, recordamos o direito de todos os Estados partes, inclusive a República Islâmica do Irã, de desenvolver pesquisa, produção e uso de energia nuclear (o ciclo do combustível nuclear, inclusive atividades de enriquecimento) para fins pacíficos, sem discriminação.

2. Expressamos nossa forte convicção de que temos a oportunidade de começar um processo prospectivo, que criará uma atmosfera positiva, construtiva, não confrontacional, conducente com uma era de interação e cooperação.

3. Acreditamos que a troca de combustível nuclear é instrumental para iniciar a cooperação em diferentes áreas, especialmente no que diz respeito à cooperação nuclear pacífica, incluindo construção de usinas nucleares e de reatores de pesquisa.

4. Com base nesse ponto, a troca de combustível nuclear é um ponto de partida para o começo da cooperação e um passo positivo e construtivo entre as nações. Tal passo deve levar a uma interação positiva de cooperação no campo das atividades nucleares pacíficas, substituindo e evitando todo tipo de confrontação, abstendo-se de medidas, ações e declarações retóricas que possam prejudicar os direitos e as obrigações do Irã sobre o TNP.

5. Baseado no que precede, de forma a facilitar a cooperação nuclear mencionada acima, a República Islâmica do Irã concorda em depositar 1200 $\mathrm{kg}$ de urânio levemente enriquecido (LEU) na Turquia. Enquanto estiver na Turquia, esse urânio continuará a ser propriedade do Irã. O Irã e a AIEA 
poderão estacionar observadores para monitorar a guarda de urânio na Turquia.

6. O Irã notificará a AIEA por escrito, por meio dos canais oficiais, sobre a sua concordância com o exposto acima, em até sete dias após a data desta Declaração. Quando da resposta positiva do Grupo de Viena (EUA, Rússia, França e AIEA), outros detalhes da troca serão elaborados por meio de um acordo escrito e dos arranjos apropriados entre o Irã e o Grupo de Viena, que se comprometerá, especificamente, a entregar os $120 \mathrm{~kg}$ de combustível necessários ao reator de pesquisas de Teerã.

7. Quando o Grupo de Viena manifestar seu acordo com essa medida, ambas as partes implantarão o acordo previsto no parágrafo 6. A República Islâmica do Irã expressa estar pronta - em conformidade com o acordo - a depositar seu LEU dentro de um mês. Com base no mesmo acordo, o Grupo de Viena deve entregar $120 \mathrm{~kg}$ do combustível requerido para o reator de pesquisas de Teerã em não mais que um ano.

8. Caso as cláusulas desta Declaração não forem respeitadas, a Turquia, mediante solicitação iraniana, devolverá, rápida e incondicionalmente, o LEU ao Irã.

9. A Turquia e o Brasil saudaram a continuada disposição da República Islâmica do Irã em buscar as conversas com os países 5+1 em qualquer lugar, inclusive na Turquia e no Brasil, sobre as preocupações comuns, com base em compromissos coletivos e de acordo com os pontos comuns de suas propostas.

10. A Turquia e o Brasil apreciam o compromisso iraniano com o TNP e seu papel construtivo na busca da realização dos direitos na área nuclear dos Estados-Membros. A República Islâmica do Irã apreciou os esforços construtivos dos países amigos, a Turquia e o Brasil, na criação de um ambiente conducente à realização dos direitos do Irã na área nuclear. 
ManucherMottaki

Ministro dos Negócios Estrangeiros da República Islâmica do Irã

Ahmet Davutoglu

Ministro dos Negócios Estrangeiros da República da Turquia

\author{
Celso Amorim
}

Ministro das Relações Exteriores da República Federativa do Brasil 


\section{ANEXO 3: Fotos}

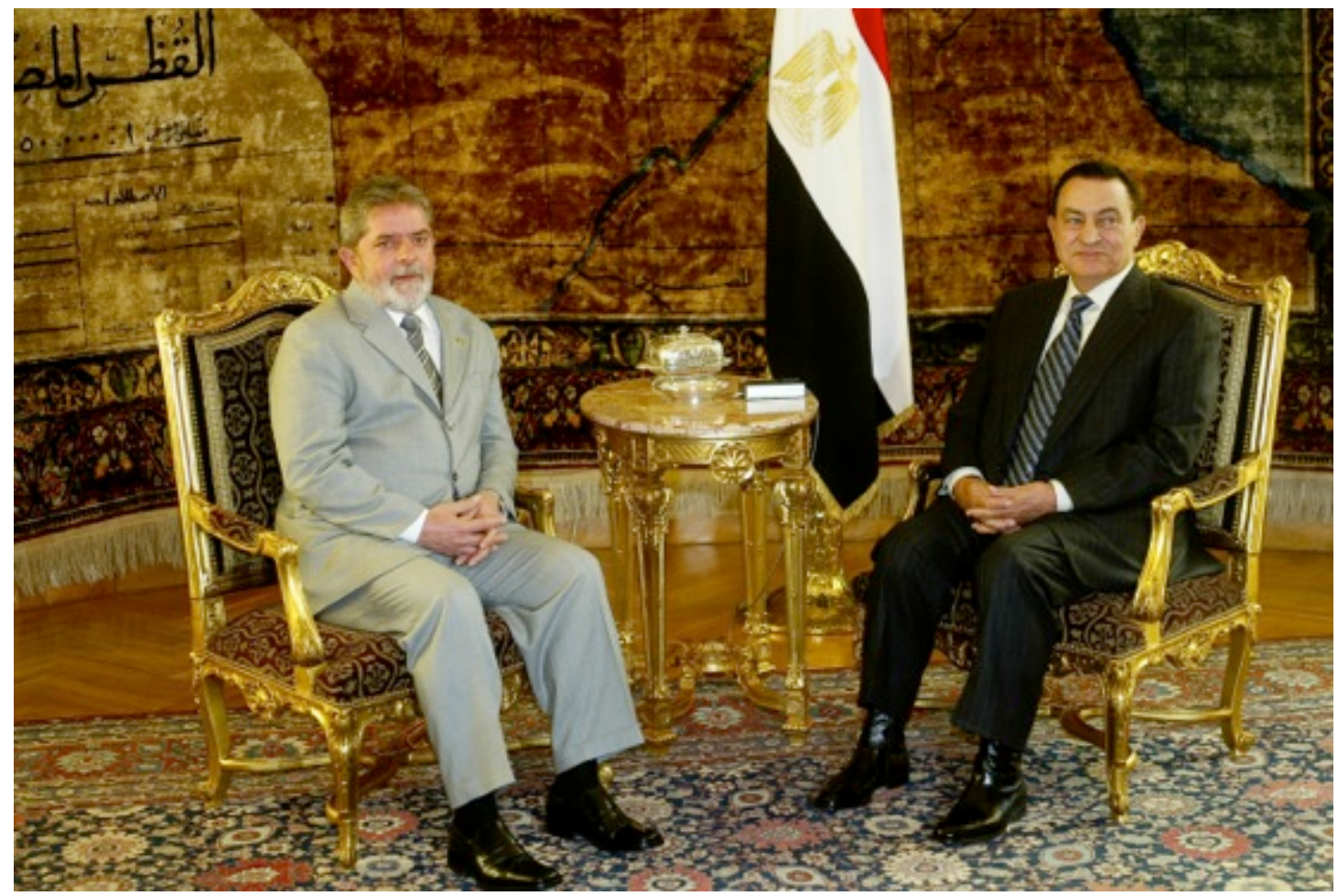

O ex-presidente Luiz Inácio Lula da Silva em visita oficial ao ex-presidente do Egito, Hosni Mubarak (Alan Marques/ Folhapress) - dez. 2003.

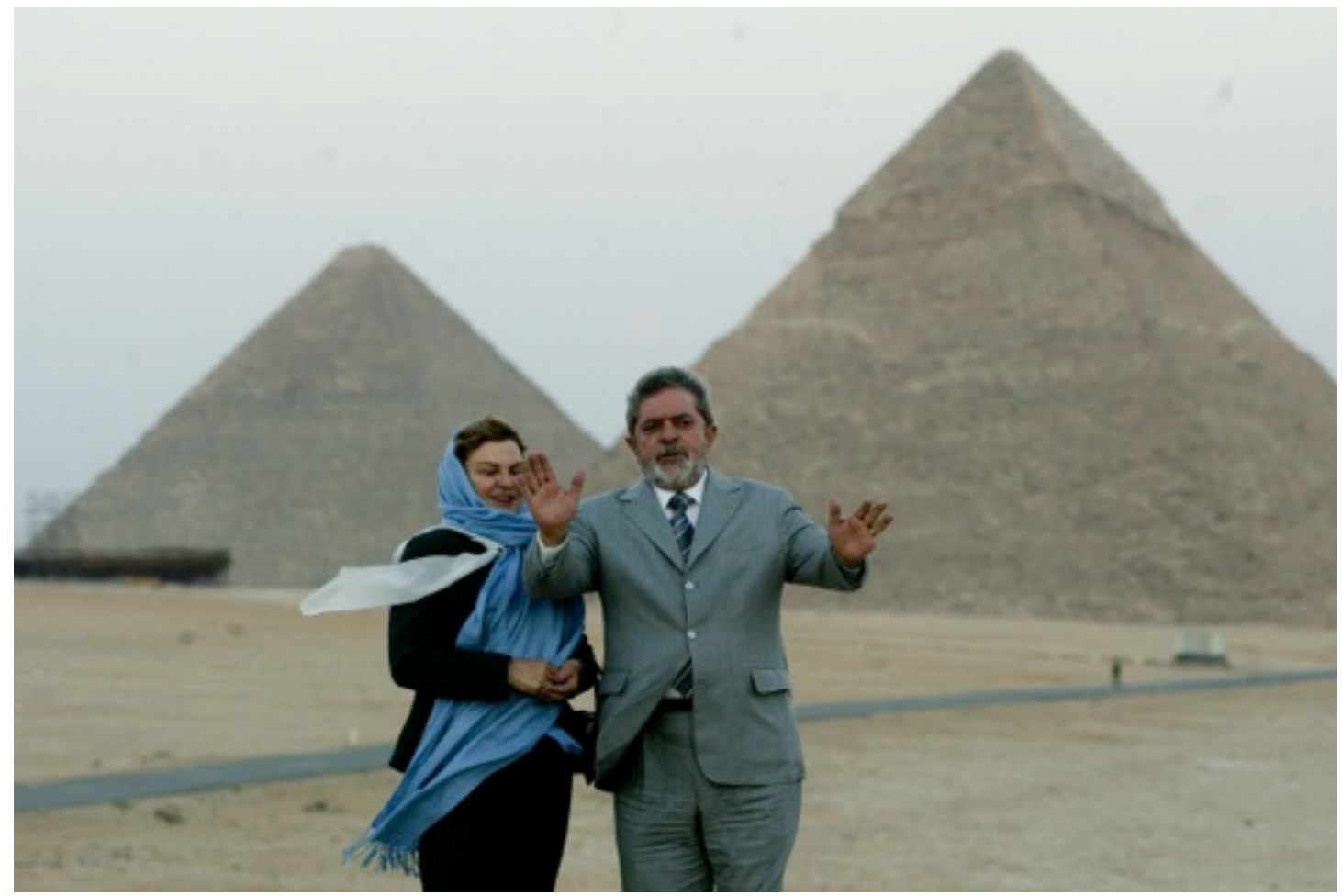

O ex-presidente Luiz Inácio Lula da Silva e sua esposa, Marisa Letícia, em visita oficial Egito (Alan Marques/ Folhapress) - dez. 2003. 


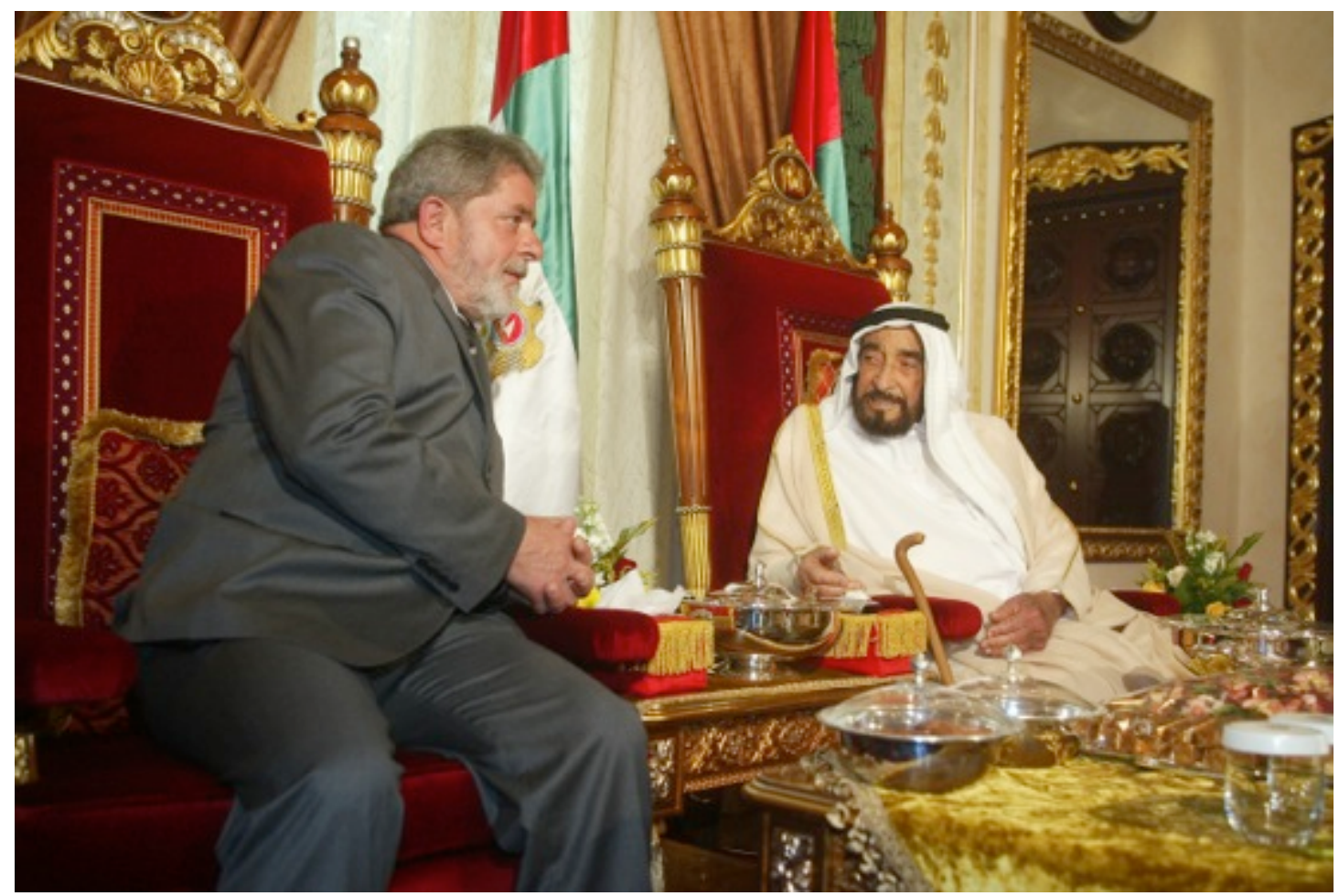

O ex-presidente Luiz Inácio Lula da Silva em reunião de trabalho com o ex-presidente dos Emirados Árabes Unidos, Zayed Bin Sultan (Alan Marques/ Folhapress) - dez. 2003.

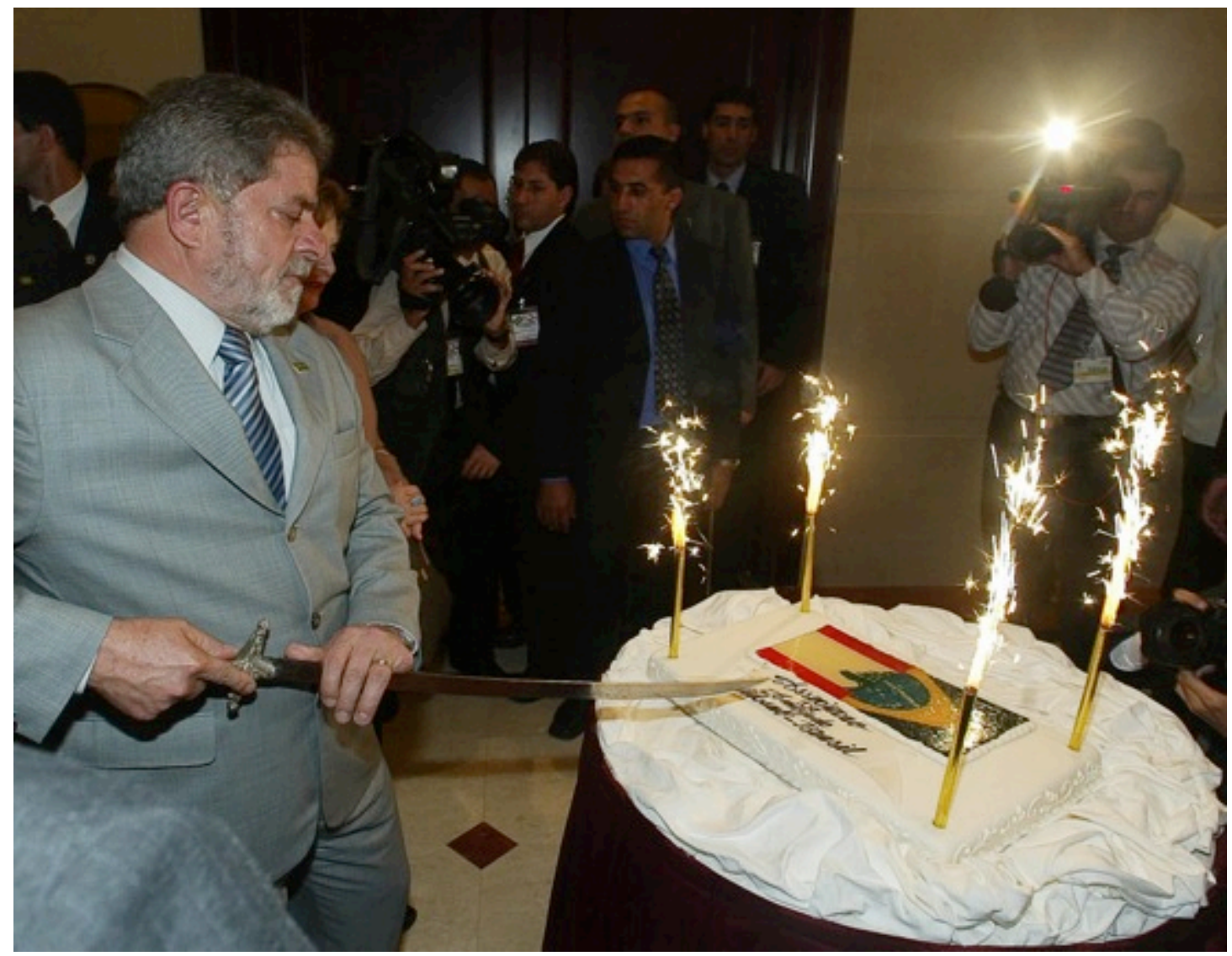

O ex-presidente Luiz Inácio Lula da Silva em visita oficial ao Líbano (Alan Marques/ Folhapress) dez. 2003. 


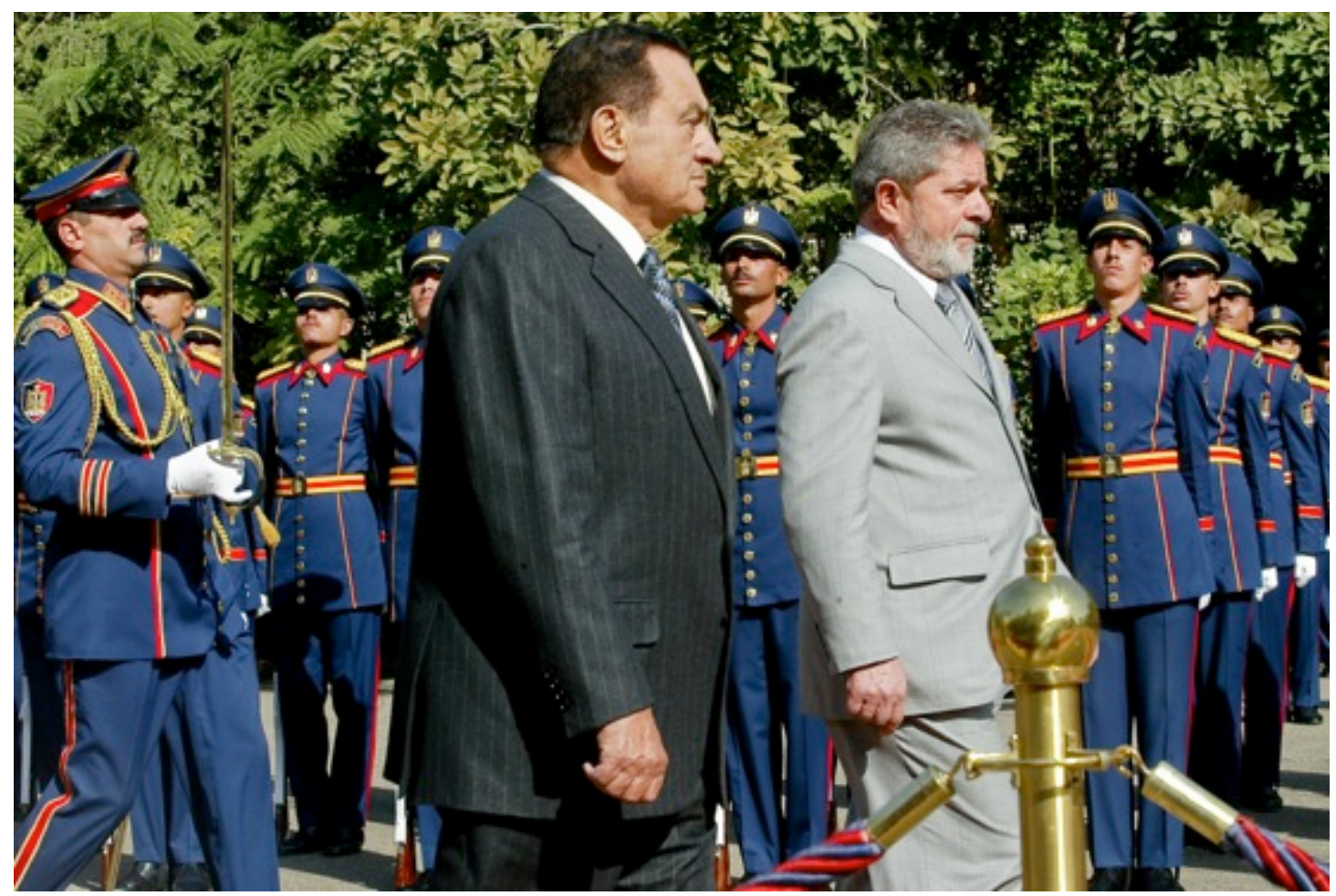

O ex-presidente Luiz Inácio Lula da Silva em visita oficial ao ex-presidente do Egito, Hosni Mubarak (Alan Marques/ Folhapress) - dez. 2003.

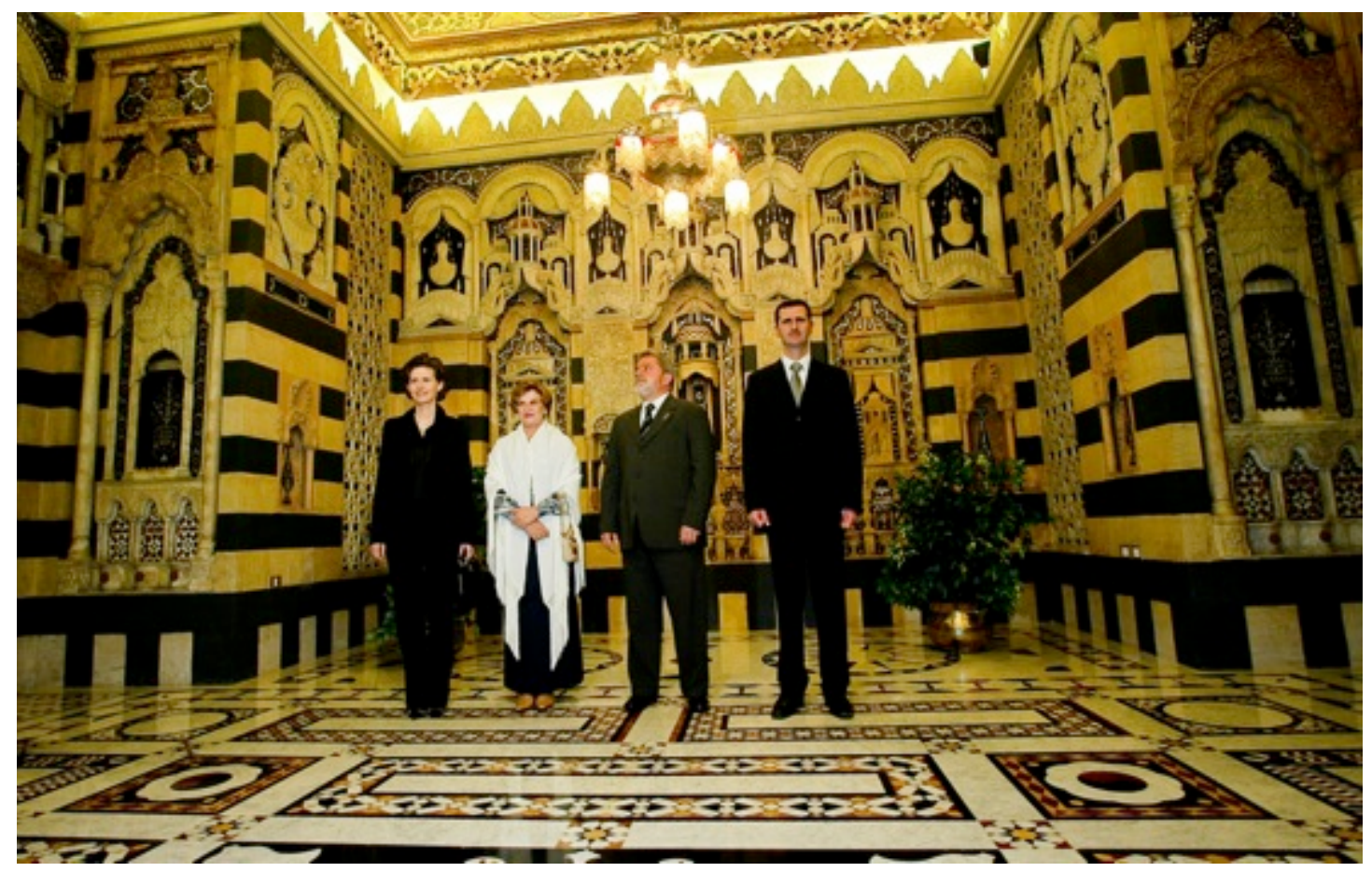

O ex-presidente Luiz Inácio Lula da Silva em visita oficial ao presidente da Síria, Bashar al-Assad (Alan Marques/ Folhapress) - dez. 2003. 